\title{
Rúbia Kuno
}

\section{Valores de referência para chumbo, cádmio e mercúrio em população adulta da Região Metropolitana de São Paulo}

Tese apresentada à Faculdade de Medicina da

Universidade de São Paulo para obtenção do título de Doutor em Ciências

Área de concentração: Medicina Preventiva Orientador: Prof. Dr. Nelson da Cruz Gouveia

São Paulo 
Dados Internacionais de Catalogação na Publicação (CIP)

Preparada pela Biblioteca da

Faculdade de Medicina da Universidade de São Paulo

Creprodução autorizada pelo autor

\section{Kuno, Rúbia}

Valores de referência para chumbo, cádmio e mercúrio em população adulta da Região Metropolitana de São Paulo / Rúbia Kuno. -- São Paulo, 2009.

Tese(doutorado)--Faculdade de Medicina da Universidade de São Paulo.

Departamento de Medicina Preventiva.

Área de concentração: Medicina Preventiva.

Orientador: Nelson da Cruz Gouveia.

Descritores: 1.Valores de referência 2.Chumbo/sangue 3.Cádmio/sangue 4.Mercúrio/sangue 5.Monitoramento ambiental 6.Qualidade ambiental 7.Saúde ambiental

USP/FM/SBD-081/09 
Ao Thiago, Ana Maria e Chris, por todo carinho, apoio e compreensão 


\section{Agradecimentos}

Ao meu orientador Prof. Dr. Nelson da Cruz Gouveia, pela orientação competente e tranqüila, e pela paciência, que muitas vezes demonstrou ao respeitar as atividades profissionais que desempenhei paralelamente às de doutorado.

À Colsan/UNIFESP que tornou possível este estudo. Em especial ao Dr. Fabrício Oliveira Carvalho, Diretor Técnico-Científico e Dr. José Augusto Barreto, Diretor Superintendente, que atenderam prontamente a nossa solicitação de utilizar amostras de sangue dos doadores dessa instituição, e desde o primeiro contato demonstraram grande interesse e disponibilidade em ajudar. Não poderíamos deixar de agradecer a todos os trabalhadores da Colsan, tanto dos postos de coleta, como da sede, que sempre foram tão prestativos e gentis com a nossa equipe.

Aos amigos da Cetesb, Maria Helena, Simone Harue e Yoshio pelo apoio e ajuda em todos os momentos que precisei. À equipe do Setor de Análises Toxicológicas (EAMM) Viana, Carlão, Genival, Daniela, estagiários Fabinho, Rafael e Pedro pela ajuda na coleta de amostras, que juntos com a nossa equipe conseguiram a façanha de coletar 653 amostras em apenas um mês, trabalhando inclusive aos sábados. Também ao EAMM agradeço pelas análises de chumbo e cádmio, especialmente ao dr. Gilson Quinaglia, gerente do setor. 
À dra. Gisela Umbuzeiro, minha gerente, pelo incentivo para que eu trilhasse mais esse caminho, pelas sugestões sempre muito pertinentes, e pelo entusiasmo e disposição em ajudar, o que foi fundamental para superar as dificuldades encontradas na realização deste estudo.

À UBA, Agência Ambiental Federal da Alemanha, em nome da dra. Kerstin Becker e dra. Margarete Seiwert, por terem viabilizado a cooperação entre essa entidade e a Cetesb, pelos inúmeros esclarecimentos solicitados por email e prontamente respondidos quanto à elaboração do questionário e dúvidas na análise estatística dos resultados. E evidentemente, pelas análises de mercúrio, realizadas sem qualquer ônus para o projeto.

À $\operatorname{Prof}^{\mathrm{a}} \operatorname{Dr}^{\mathrm{a}}$ Nilza Nunes da Silva do Departamento de Epidemiologia da FSP-USP pelo cálculo do tamanho da amostra.

Ao Prof. Dr. Eduardo De Capitani da UNICAMP pelas sugestões na elaboração do questionário.

Aos amigos do Departamento de Medicina Preventiva: Mateus, Marina e Miriam pelo apoio e, Rogério, pela orientação na análise estatística.

À Cetesb por ter permitido a minha participação no curso de doutorado e por ter viabilizado o projeto.

Em especial aos doadores de sangue da Colsan e aos funcionários da Cetesb (estudo piloto), sem os quais seria impossível realizar o estudo. 
Aos meus filhos queridos Thiago e Ana Maria, ao Christiano, meu companheiro de todas as horas, pela paciência e compreensão pela ausência em alguns momentos desses anos. 


\section{Sumário}

Lista de Abreviaturas

Lista de Figuras

Lista de Tabelas

Lista de Quadros

Resumo

Summary

1 INTRODUÇÃO

2 REVISÃO DA LITERATURA

2.1 Metodologia de derivação de valor de referência

2.1.1 Seleção dos indivíduos para a produção de valores de referência

2.1.2 Tamanho da amostra, determinação dos valores de referência e apresentação dos Valores ou Intervalos de Referência

2.2 Toxicologia dos metais

2.2.1 Toxicologia do chumbo 34

2.2.2 Toxicologia do Cádmio .43

2.2.3 Toxicologia do Mercúrio.

4 MÉTODOS .54

4.1 Período e desenho do estudo .54

4.2 Estudo piloto e cálculo do tamanho da amostra .54

4.3 População de estudo .59

4.4 Coleta de amostra e aplicação do questionário .60

4.5 Aspecto ético da pesquisa .66 
4.6 Análise dos metais em sangue ..........................................68

4.6.1 Determinação de chumbo e cádmio ..............................68

4.6.2 Determinação de mercúrio total...................................71

4.7 Tratamento dos dados/Análise estatística .................................72

4.7.1 Valores de referência para chumbo, cádmio e mercúrio .....73

4.7.2 Análise univariada .................................................... 74

4.7.3 Análise de regressão linear múltipla ...............................75

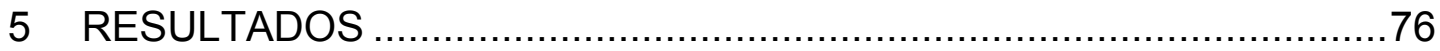

5.1 População estudada .............................................................

5.2 Resultados de metais em sangue ........................................... 80

5.3 Valores de referência para os metais segundo sexo e faixa etária

6 DISCUSSÃO 100

6.1 Valores de referência propostos para chumbo, cádmio e mercúrio 100

6.1.1 Chumbo ................................................................ 105

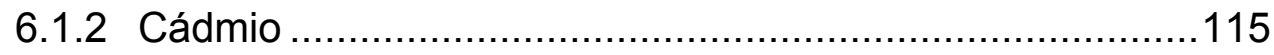

6.1.3 Mercúrio..............................................................119

6.2 Utilização de doadores de sangue para derivação de VR e a representatividade da amostra.

6.3 Controle de qualidade analítica e limite de quantificação do método de determinação de contaminantes ambientais.

7 CONCLUSÕES E RECOMENDAÇÕES 129

8 ANEXOS 132

9 REFERÊNCIAS 


\section{Lista de Abreviaturas}

ACGIH - American Conference of Government Industrial Hygienists

ס-ALA-D - Enzima $\delta$-aminolevulínico desidratase eritrocitária

ANCOVA - Análise de Covariância

ANOVA - Análise de Variância

ANVISA - Agência Nacional de Vigilância Sanitária

ANVISA/REBLAS - Agência Nacional de Vigilância Sanitária/Rede Brasileira de Laboratórios Analíticos em Saúde

As - Arsênio

ATSDR - Agency for Toxic Substances and Disease Registry, é uma agência federal de saúde pública da U.S. Department of Health and Human Services BEI - Biological Exposure Índice

$\mathrm{BH}$ - Biomonitorização humana

CAPPesq - Comissão de Ética para Análise de Projetos de Pesquisa da Diretoria Clínica do Hospital das Clínicas e da Faculdade de Medicina da Universidade de São Paulo

Cd - Cádmio

CDC - Centers for Disease Control and Prevention do U.S. Department of Health and Human Services

Cetesb - Companhia de Tecnologia de Saneamento Ambiental CGVAM - Coordenação Geral de Vigilância em Saúde Ambiental da SVS cis- $\mathrm{Cl}_{2} \mathrm{CA}$ - Ácido cis-3-(2,2-diclorovinil)-2,2-dimetilciclopropano-carboxílico cm - Centímetro 
Colsan - Associação Beneficente de Coleta de Sangue

CONEP - Conselho Nacional de Ética em Pesquisa do Ministério da Saúde

DDE - Dicloro-difenil-dicloroetileno

DDT - Dicloro-difenil-tricloroetano

DEHP - Di(2-etilhexil)ftalato

DEP - Dietil fosfato

DMP - Dimetil fosfato

DMTP - Dimetiltiofosfato

DNA - Ácido desoxirribonucleico

DP - Desvio padrão

GerES - German Environmental Survey

GI - Trato gastrintestinal

HBM - Human Biological Monitoring - biomonitorização humana limites

máximos toleráveis estabelecidos pela Alemanha

HBM I - Valor limite do biomarcador, estabelecido pela Alemanha, abaixo do qual não há risco de efeitos adversos à saúde

HBM II - Valor limite do biomarcador, estabelecido pela Alemanha, acima do qual há um aumento do risco de efeitos adversos à saúde nos indivíduos susceptíveis

HCB - hexaclorobenzeno

$\beta$-HCH - $\beta$-hexaclorocicloexano

Hg - Mercúrio

$\mathrm{Hg}^{0}$ - Mercúrio elementar

$\mathrm{HgCl}_{2}$ - Cloreto mercúrico 
HIV I e II - Vírus da Imunodeficiência Humana

HPAs - Hidrocarbonetos policíclicos aromáticos

HTLV I e II - Vírus linfotrópicos humanos de células-T

IAL - Instituto Adolfo Lutz

IBMP - Índice Biológico Máximo Permitido

IC95\% - Intervalo de 95\% de confiança

IFCC - International Federation of Clinical Chemistry

IMC - Índice de Massa Corpórea

IRPTC - International Register of Potentially Toxic Chemical do Programa

das Nações Unidas para o Meio Ambiente

IUPAC - International Union of Pure and Applied Chemistry

LEO - Limites de Exposição Ocupacional

LnCd - Logaritmo natural das concentrações de cádmio

LnHg- Logaritmo natural das concentrações de mercúrio

LnPb - Logaritmo natural das concentrações de chumbo

LQ - Limite de quantificação

LT - Limites de Tolerância

MAX - Valor máximo

MeHg - Metilmercúrio

MG - Média geométrica

$\mu \mathrm{g} / \mathrm{dL}$ - Micrograma por decilitro

$\mu \mathrm{g} / \mathrm{g}$ - Micrograma por grama

$\mu \mathrm{g} / \mathrm{L}-$ Micrograma por litro

$\mu \mathrm{g} / \mathrm{m}^{3}$ - Micrograma por metro cúbico 
$\mu \mathrm{m}$ - Micrômetro

$\mathrm{mg} / \mathrm{kg}$ - Miligrama por quilo

$\mathrm{mmHg}$ - Milímetro de mercúrio

MLG - Modelo Linear Geral

$N<L Q$ - Resultados abaixo do limite de quantificação

$\mathrm{NH}_{4} \mathrm{H}_{2} \mathrm{PO}_{4}$ - Fosfato de amônio

NHANES - National Health and Nutrition Examination Survey, estudo

populacional dos EUA

Ni-Cd - Níquel-cádmio

NRC - National Research Council, entidade não - governamental dos EUA

que dá subsídios ao governo americano na área de ciência, tecnologia e saúde para adoção de políticas

OEL - Occupational Exposure Limits

5 oxo-MEHP - Mono -(2-etil-5-oxohexil)ftalato

5OH-MEHP - Mono-(2-etil-5-hidroxihexil)ftalato

PA - variável pressão alterada

$\mathrm{Pb}-$ Chumbo

3-PBA - ácido 3-fenoxibenzóico

PCBs - bifenilas policloradas

$\mathrm{p} / \mathrm{v}$ - Peso por volume

P10 - Percentil 10

P30 - Percentil 30

P50 - Percentil 50

P65 - Percentil 65 
P90 - Percentil 90

P95 - Percentil 95

P97,5 - Percentil 97,5

PVC - Policloreto de vinila

QI - Quociente de inteligência

Rh - Ródio

RMSP - Região Metropolitana de São Paulo

SPSS - Statistical Package for the Social Sciences

SVS - Secretaria de Vigilância em Saúde do Ministério da Saúde

TCA - Ácido tricloroacético

TLVs - Threshold Limit Values

trans- $\mathrm{Cl}_{2} \mathrm{CA}$ - Ácido trans-3-(2,2-diclorovinil)-2,2-dimetilciclopropano-

carboxílico

UBA - Umwelt Bundes Amt, Agência Ambiental Federal da Alemanha

UGHRI 6 - Unidade de Gerenciamento de Recursos Hídricos 6, onde está

grande parte da RMSP

UNIFESP - Universidade Federal de São Paulo

USEPA - United States Environmental Protection Agency

USP - Universidade de São Paulo

$\mathrm{v} / \mathrm{v}$ - Volume por volume

VR - Valores de referência

W - Tungstênio

WHO - World Health Organization 


\section{Lista de Figuras}

Figura 1 - Definição de valores HBM da Alemanha e recomendações. .....12

Figura 2 - Os dois tipos de seleção de indivíduos para derivar valores de referência, a posteriori e a priori.

Figura 3 - Procedimento para estimar limites de referência.

Figura 4 - Rotas ambientais que contribuem para a exposição humana ao chumbo.

Figura 5 - Localização dos Postos da Colsan da Região Metropolitana de São Paulo

Figura 6 - Dinâmica da coleta de sangue nos postos da Colsan e as intervenções da pesquisa para seleção de doadores.

Figura 7 - Gráfico dos Quantis da distribuição Normal x Concentrações de metais sem transformação para logaritmo natural

Figura 8 - Gráfico dos Quantis da distribuição Normal x Concentrações de metais transformados em logaritmo natural

Figura 9 - Distribuições dos logaritmos naturais das concentrações de cádmio para as duas faixas etárias, de toda população estudada ( $A$ e $B$ ) e somente das concentrações acima do limite de quantificação (C e D)

Figura 10 - Quantis da distribuição Normal x concentrações de Cd acima do Limite de Quantificação

Figura 11 - Médias geométricas de chumbo em sangue $(\mu \mathrm{g} / \mathrm{L}) \mathrm{da}$ população estudada, segundo sexo e faixa etária.

Figura 12 - Médias geométricas de mercúrio em sangue $(\mu \mathrm{g} / \mathrm{L})$ da população estudada, segundo sexo e faixa etária

Figura 13 - Médias geométricas de cádmio $(\mu \mathrm{g} / \mathrm{L})$ segundo sexo e faixa etária 


\section{Lista de Tabelas}

Tabela 1 - Níveis de precisão, média de plumbemia (DP) e número amostral estimado por faixa etária

Tabela 2 - Bolsas coletadas no mês de setembro de 2006, por posto da Colsan e número de amostras calculadas proporcionalmente ao número de bolsas coletadas.

Tabela 3 - Comparação dos resultados das análises de chumbo e cádmio em amostras de sangue $(\mu \mathrm{g} / \mathrm{L})$, realizadas nos laboratórios da UBA e da Cetesb

Tabela 4 - Número de indivíduos que tiveram amostras de sangue analisadas quanto ao conteúdo de $\mathrm{Pb}, \mathrm{Cd}$ e $\mathrm{Hg}$, e número de perdas, segundo sexo e faixa etária

Tabela 5 - Distribuição dos doadores pesquisados, segundo posto de coleta da Colsan localizados na RMSP. Novembro de 2006 ...77

Tabela 6 - População estudada, segundo faixa etária (anos), nível de escolaridade e renda per capita (reais)

Tabela 7 - Distribuição dos doadores segundo município de residência ..79

Tabela 8 - Distribuição das concentrações ( $\mu \mathrm{g} / \mathrm{L})$ de $\mathrm{Pb}, \mathrm{Cd}$ e $\mathrm{Hg}$ no sangue da população estudada

Tabela 9 - Relação de potenciais determinantes com concentração de chumbo em sangue: Estimativa do parâmetro, Erro padrão, IC95\% da Estimativa do parâmetro e significância $(p)$ na Regressão Linear Univariada

Tabela 10 - Relação de potenciais determinantes com concentração de mercúrio em sangue: Estimativa do parâmetro, Erro padrão, IC95\% da Estimativa do parâmetro e significância $(p)$ na Regressão Linear Univariada

Tabela 11 - Resultados da regressão linear múltipla relativa à associação significativa $(p \leq 0,05)$ entre concentração de chumbo em sangue e as variáveis explicativas

Tabela 12 - Resultados da regressão linear múltipla relativa à associação significativa $(p \leq 0,05)$ entre concentração de mercúrio em sangue e as variáveis explicativas 
Tabela 13 - Relacionamento das variáveis sexo e faixa etária com os níveis de chumbo no sangue.

Tabela 14 - Relacionamento das variáveis sexo e faixa etária com os níveis de mercúrio no sangue.....

Tabela 15 - Relacionamento das variáveis sexo e faixa etária com os níveis de cádmio no sangue

Tabela 16 - Valores de referência para $\mathrm{Pb}, \mathrm{Cd}$ e $\mathrm{Hg}$ em sangue ( $\mu \mathrm{g} / \mathrm{L})$, derivados dos valores ajustados a partir das distribuições e corrigidos no caso do cádmio

Tabela 17 - Distribuição dos casos de concentração de Cd em sangue acima dos valores de referência (VR).

Tabela 18 - Distribuição dos casos de concentração de Pb em sangue acima dos valores de referência

Tabela 19 - Distribuição dos casos de concentração de Hg em sangue acima dos valores de referência

Tabela 20 - Valores e intervalos de referência propostos para chumbo, cádmio e mercúrio em sangue de adultos ( $\mu \mathrm{g} / \mathrm{L})$ em diversas populações

Tabela 21 - Médias anuais das concentrações de chumbo no ar em quatro estações de monitoramento da Cetesb. 1993 a 2003111 


\section{Lista de Quadros}

Quadro 1 - Principais alterações realizadas no questionário do estudo piloto para ser usado no estudo com doadores

Quadro 2 - Descrição das informações incluídas no questionário dos doadores de sangue com as justificativas para sua inclusão.....64 


\section{Resumo}

Kuno R. Valores de referência para chumbo, cádmio e mercúrio em população adulta da Região Metropolitana de São Paulo [tese]. São Paulo: Faculdade de Medicina, Universidade de São Paulo; 2009. 166p.

O uso de biomarcadores para avaliar a exposição da população humana a contaminantes ambientais, a biomonitorização humana (BH), fornece uma relação direta entre exposição à substância química e a dose interna. Os resultados da BH da população geral devem ser comparados com valores de referência (VR), obtidos de um grupo definido da população geral e derivados por método estatístico. Esses VR, em geral, determinam o limite superior da exposição basal. O objetivo deste estudo foi derivar VR de chumbo, cádmio e mercúrio em sangue para a população adulta da Região Metropolitana de São Paulo (RMSP), e verificar associação entre os níveis desses metais no sangue e variáveis sócio-demográficas e de estilo de vida. Foram coletadas amostras de doadores de sangue em 9 postos de coleta em 2006, que residiam na RMSP, não fumantes e sem exposição ocupacional aos metais estudados. Informações sobre as variáveis de interesse foram obtidas por meio de questionário. Os VR derivados correspondem ao limite superior do IC95\% do P95, e foram para homens de 18 a 39 anos $59,73 \mu \mathrm{g} / \mathrm{L}$ para $\mathrm{Pb}, 0,41 \mu \mathrm{g} / \mathrm{L}$ para $\mathrm{Cd}$ e 4,30 $\mu \mathrm{g} / \mathrm{L}$ para $\mathrm{Hg}$; para mulheres $47,09 \mu \mathrm{g} / \mathrm{L}$ para $\mathrm{Pb}, 0,48 \mu \mathrm{g} / \mathrm{L}$ para $\mathrm{Cd}$ e $3,71 \mu \mathrm{g} / \mathrm{L}$ para $\mathrm{Hg}$. Para homens de 40 a 65 anos $79,84 \mu \mathrm{g} / \mathrm{L}$ para $\mathrm{Pb}$, $0,35 \mu \mathrm{g} / \mathrm{L}$ para $\mathrm{Cd}$ e $5,10 \mu \mathrm{g} / \mathrm{L}$ para $\mathrm{Hg}$; para mulheres $63,10 \mu \mathrm{g} / \mathrm{L}$ para $\mathrm{Pb}$, $0,44 \mu \mathrm{g} / \mathrm{L}$ para $\mathrm{Cd}$ e $6,10 \mu \mathrm{g} / \mathrm{L}$ para $\mathrm{Hg}$. Os VR de chumbo mostraram-se inferiores aos derivados para a população de Londrina (Brasil), foram semelhantes aos da República Checa e Alemanha, mas superiores aos do estudo populacional dos EUA (NHANES). Os VR de Cd foram bem inferiores aos das populações desses países, cujos valores estão acima de $1 \mu \mathrm{g} / \mathrm{L}$. Os VR de $\mathrm{Hg}$ foram semelhantes aos dos EUA e superiores aos da Alemanha e República Checa. Os níveis de $\mathrm{Pb}$ e Cd em sangue apresentaram associação significativa com sexo e faixa etária. Homens apresentaram $50 \%$ mais chumbo em sangue, e indivíduos entre 40 e 65 anos apresentaram $23 \%$ mais chumbo em relação aos de 18 a 39 anos. A variável que mais contribuiu para os níveis de $\mathrm{Hg}$ foi consumo de peixe, sendo que o consumo diário ou mais que uma vez por semana foi associado a um aumento de $107 \%$ de mercúrio em sangue em relação à categoria que não consome peixe. Possuir restauração de amálgama aumentou $24 \%$ os níveis de mercúrio, e ter entre 40 e 65 anos aumentou $19 \%$ em relação à faixa de 18 a 39 anos. Níveis de escolaridade mais baixos estiveram associados a concentrações menores de mercúrio. As médias encontradas indicam que a população estudada não está exposta a níveis preocupantes dos metais estudados. Os VR aqui propostos devem ser utilizados na comparação com dados observados em populações de características semelhantes e de áreas urbanas.

Descritores: 1.Valores de referência 2.Chumbo/sangue 3.Cádmio/sangue 4.Mercúrio/sangue 5.Monitoramento ambiental 6.Qualidade ambiental 7.Saúde ambiental 


\section{Summary}

Kuno R. Reference values for lead, cadmium and mercury in blood of adults from the Metropolitan Area of São Paulo (Brazil) [thesis]. São Paulo: "Faculdade de Medicina, Universidade de São Paulo"; 2009. 166p.

The use of biomarkers to assess the exposure of humans to environmental contaminants, human biomonitoring (HB), provides a direct relationship between chemical exposure and internal dose. The results of the HB of the general population should be compared with reference values (RV) obtained in a defined group of the general population and derived by statistical methods. These RV generally determine the upper limit of the exposure baseline. The aim of this study was to derive RV for lead, cadmium and mercury in blood of adults from the Metropolitan Area of Sao Paulo (MASP) (Brazil), and to investigate the association between blood metals and sociodemographic and lifestyle factors. Samples from blood donors were collected in 9 blood centers in 2006, they were residents in the MASP, non smokers, and without any occupational exposure to the studied metals. Information about variables of interest was obtained by questionnaire. The $\mathrm{RV}$ derived for men aged 18 to 39 years were $59,73 \mu \mathrm{g} / \mathrm{L}$ for $\mathrm{Pb}, 0,41 \mu \mathrm{g} / \mathrm{L}$ for $\mathrm{Cd}$ e 4,30 $\mu \mathrm{g} / \mathrm{L}$ for $\mathrm{Hg}$; for women $47,09 \mu \mathrm{g} / \mathrm{L}$ for $\mathrm{Pb}, 0,48 \mu \mathrm{g} / \mathrm{L}$ for $\mathrm{Cd}$ and $3,71 \mu \mathrm{g} / \mathrm{L}$ for $\mathrm{Hg}$. For men aged 40 and 65 years $79,84 \mu \mathrm{g} / \mathrm{L}$ for $\mathrm{Pb}, 0,35 \mu \mathrm{g} / \mathrm{L}$ for $\mathrm{Cd}$ and $5,10 \mu \mathrm{g} / \mathrm{L}$ for $\mathrm{Hg}$; for women $63,10 \mu \mathrm{g} / \mathrm{L}$ for $\mathrm{Pb}, 0,44 \mu \mathrm{g} / \mathrm{L}$ for $\mathrm{Cd}$ and $6,10 \mu \mathrm{g} / \mathrm{L}$ for $\mathrm{Hg}$. The RV for lead appeared to be lower than those derived for the population of Londrina (Brazil), were similar to the Czech Republic and Germany, but higher than the one observed in a study of the U.S. population (NHANES). Conversely, RV for Cd were well below of those from these countries, which have values above $1 \mu \mathrm{g} / \mathrm{L}$. The RV for $\mathrm{Hg}$ were similar to the U.S and higher than the value in Germany and in the Czech Republic. The levels of $\mathrm{Pb}$ and $\mathrm{Cd}$ in blood showed a significant association with sex and age. Men had $50 \%$ more lead in blood, and individuals between 40 and 65 years old showed $23 \%$ more lead than those in 18 to 39 years old. The variable most related to the levels of $\mathrm{Hg}$ was fish consumption. A daily or more than once a week consumption was associated with an increase of $107 \%$ of mercury in blood when compared to a group without fish consumption. Amalgam fillings increased mercury levels in about $24 \%$, and 40 to 65 years old group had $19 \%$ more $\mathrm{Hg}$ than 18 to 39 years old. Individuals with basic education showed significantly lower mercury levels than those with higher education. The average means showed that the studied group is not exposed to high levels of these metals. The RV proposed here should be used in comparison with data observed in populations of urban areas with similar characteristics.

Descriptors: 1.Reference values 2.Lead/blood 3.Cadmium/blood 4.Mercury/blood 5.Environmental monitoring 6.Environmental quality 7.Environmental health 


\section{I NTRODUÇÃO}

A partir do século passado, com a expansão da utilização de substâncias químicas na indústria e na agricultura, o homem viu-se exposto a essas substâncias tanto no ambiente de trabalho como no seu macroambiente, o que passou a exigir um estudo minucioso desses xenobióticos (compostos de origem externa ao organismo) quanto aos seus efeitos biológicos e toxicológicos. Pesquisas foram feitas com a finalidade de desenvolver métodos práticos para a medida direta desses eventos biológicos ou respostas que resultam da exposição humana aos xenobióticos (Decaprio, 1997; Apostoli, 2002). Essa medida direta é realizada por meio de "marcadores biológicos" ou "biomarcadores", ou ainda "indicador biológico", que refletem as alterações moleculares e ou celulares que ocorrem em um sistema ou amostra biológica de um organismo. O National Research Council (NRC, 1987) classifica os biomarcadores em três tipos, de exposição, de efeito e de suscetibilidade, os quais indicam a evolução de eventos e comportamento do organismo frente à exposição.

\section{Biomarcadores}

De maneira geral, pode-se definir o biomarcador de efeito como qualquer mudança que pode predizer quali ou quantitativamente um dano à 
saúde ou indicar a existência de condições que podem resultar em prejuízo à saúde decorrente de uma exposição. Por exemplo, a inibição da atividade da enzima $\delta$-aminolevulínico desidratase eritrocitária ( $\delta$-ALA-D) é um biomarcador de efeito decorrente da exposição ao chumbo inorgânico; e a microproteinúria, que indica alteração nos túbulos renais, decorrente de exposição ao cádmio.

O biomarcador de suscetibilidade exprime uma condição adquirida ou congênita e tem como base a capacidade limitada do organismo de fazer frente à exposição a um xenobiótico. Esses biomarcadores de suscetibilidade incluem diferenças inatas de metabolismo, variação nos níveis de imunoglobulinas, e outras variações na absorção, metabolismo, e resposta a agentes ambientais. Finalmente, o biomarcador de exposição pode ser a identificação de uma substância exógena ao organismo em tecidos e fluidos, o produto de interação entre o xenobiótico e componentes endógenos, ou outro evento no sistema biológico relacionado à exposição. Esse biomarcador expressa a dose interna, isto é, a quantidade do xenobiótico que realmente é absorvida pelo organismo (NRC, 1987; Della Rosa et al., 2008).

Idealmente, um biomarcador de exposição deve ter uma medida que varie de acordo com a intensidade da exposição (especialmente a baixas doses), deve ser específico para a exposição ambiental em questão, detectável em quantidades traços, possível de ser obtido por técnicas não invasivas e ter baixo custo analítico. Atualmente há poucos biomarcadores que possuem todas essas características, mas mesmo assim é crescente o 
seu uso para avaliar a exposição, pois são indicadores altamente sensíveis da exposição individual a contaminantes, que possibilitam a medida da dose interna e integram todas as vias e fontes de exposição. Os biomarcadores também podem indicar exposição passada (p.ex. a presença de chumbo em dentes decíduos), exposição recente a uma fonte externa (como a determinação de composto orgânico volátil no ar expirado) e até mesmo exposições futuras a fontes internas (no caso de pesticidas acumulados em tecido adiposo) (World Health Organization - WHO, 2000a).

Esses marcadores são também ferramentas úteis na vigilância à saúde para monitorar a exposição de indivíduos ou populações a substâncias químicas, pois fornecem dados mais precisos do que a avaliação da exposição via determinação dos xenobióticos no ambiente (WHO, 2000a). Por exemplo, grupos de população "sob risco" podem ser identificados quando os valores do biomarcador de exposição ou efeito desses grupos apresentam desvios em relação à média da população (WHO, 1993).

\section{Avaliação da exposição a xenobióticos}

A avaliação da exposição humana a contaminantes presentes no ambiente externo ou ambiente de trabalho vem sendo tradicionalmente estimada pela medida periódica dos contaminantes em amostras ambientais tais como ar, água e solo, denominada monitorização ambiental. Essa 
avaliação, se combinada com as medidas periódicas de determinada substância química ou seu metabólito na população exposta (biomonitorização humana-BH), pode melhorar a qualidade das avaliações de risco, pois fornece uma relação direta entre exposição à substância química e a dose interna, e possíveis efeitos à saúde (WHO, 1993). Também o uso de marcadores de exposição pode auxiliar o diagnóstico clínico quando a relação entre o biomarcador e o efeito já está bem estabelecida (WHO, 2000a).

Dessa maneira, a $\mathrm{BH}$ complementa a monitorização ambiental e é utilizada usualmente em Saúde Ocupacional e Ambiental para verificar a adequação com os padrões legais definidos para cada substância. Assim, a monitorização da exposição de trabalhadores ou da população geral é um procedimento que consiste em uma rotina de avaliação e interpretação de parâmetros biológicos e/ou ambientais, com a finalidade de detectar os possíveis riscos à saúde comparando-se com referências apropriadas (Berlin et al., 1984* apud Apostoli, 1999).

$\mathrm{A} B \mathrm{BH}$ vem sendo utilizada há mais de meio século na indústria como estratégia de prevenção na vigilância médica de trabalhadores (Boogaard, 2007). Porém nos últimos 20 anos é crescente a sua utilização como uma ferramenta para políticas em saúde ambiental (United States Environmental Protection Agency - U.S.EPA, 2003). Mais do que as medidas realizadas no ambiente externo, ela fornece informações sobre a "poluição individual". Na área ambiental, a BH não

\footnotetext{
${ }^{*}$ Berlin A, Yodaiken RR, Henman BA. Assessment of toxic agents at the workplace. Roles of ambient biological monitoring. Hague Nijhoft, Boston, 1984.
} 
apenas fornece informações valiosas sobre a exposição e seus possíveis efeitos na saúde, mas também é de grande utilidade na identificação preventiva de riscos, e serve de base para a adoção e avaliação de políticas ambientais (Casteleyn et al., 2007).

Um fato muito importante que colocou definitivamente os indicadores biológicos como instrumentos valiosos na avaliação da exposição ambiental da população geral, foi o desenvolvimento da química analítica que possibilitou a determinação de compostos em concentrações muito baixas nas diversas matrizes biológicas, já que os níveis de exposição da população geral usualmente são mais baixos do que os níveis aos quais os trabalhadores estão submetidos (Mutti, 1999). No passado era usual a detecção desses contaminantes apenas em trabalhadores expostos, pois os limites de detecção praticados eram muito altos. Esse fato levava ao errôneo entendimento de que os contaminantes não estavam presentes na população considerada não exposta, hoje sabe-se que isso não é verdade, especialmente para os metais que são compostos naturalmente presentes na biosfera terrestre.

Os dados de biomonitorização humana têm crescido de tal forma que nos últimos 20 anos estes vêm sendo utilizados para estabelecer e revisar limites de exposição ocupacional, e para fornecer dados sobre exposição nos processos de avaliação de risco. Como parte dessa estratégia, é fundamental conhecer os níveis basais de exposição da população geral, os chamados valores ou intervalos de referência (Levy et al., 2007). 


\section{Valores de referência e valores máximos admissíveis}

O emprego de valores de referência (VR) sempre esteve relacionado à interpretação de resultados de exames de análises clínicas. Os médicos geralmente usam o termo "valor normal", enquanto que os toxicologistas preferem o termo "níveis background". O termo "valores normais", dependendo do contexto utilizado, pode significar o valor associado com a ausência de doença (não-patológico, sadio) ou o valor normalmente encontrado na população (comum, freqüente, típico) (Apostoli, 1999).

Devido ao aumento do conhecimento sobre as variações nos componentes do organismo humano decorrentes de processos fisiológicos e patológicos, diferenças genéticas e fatores ambientais, tornou-se necessária uma interpretação mais precisa e abrangente dos exames de laboratório. Para essa interpretação é necessário conhecer como ocorrem essas variações nos sujeitos em estudo e este conhecimento é obtido com valores de um ou mais indivíduos de "referência" (Solberg, 1987a).

O conceito de VR como uma alternativa ao valor normal para interpretar os dados de química clínica foi introduzido por Grasbeck e Saris (1969), no final dos anos 1960. Esses dois pesquisadores sugeriram que para a interpretação dos resultados das determinações laboratoriais, estes deveriam ser comparados com uma referência que seriam os valores derivados de indivíduos classificados como "controles". E os controles não seriam, necessariamente, indivíduos "saudáveis" e nem precisariam ser representativos da "população geral". Deveriam ser indivíduos com características definidas e declaradas. 
No caso do valor de referência (VR) para uma substância química em material biológico (por exemplo, sangue, urina), este é também derivado por método estatístico a partir de uma série de resultados de medidas em amostras obtidas de um grupo definido da população geral. Porém, a utilização do valor de referência é para avaliar a exposição de indivíduos ou grupos da população aos contaminantes, pois ao se comparar os dados encontrados nesses indivíduos com o valor de referência, este representa a exposição "background" ou basal (Umwelt Bundes Amt - UBA, 2008).

A simples presença da substância química ou de seu metabólito nas amostras biológicas mostra que houve exposição, ou seja, ocorreu a absorção dessa substância a partir do meio externo para o corpo, porém não significa que há risco de ocorrência de efeitos adversos para o organismo. Por isso, além dos valores de referência, é necessário estabelecer limites máximos de dose interna admissíveis ou toleráveis que protejam a saúde das populações. Esses valores limites são fundamentados em relações dose-resposta, em estudos epidemiológicos e em outros fatores como co-exposições, hábitos culturais e variáveis demográficas (Mutti, 1999).

Para o entendimento da importância e aplicação dos valores de referência (VR) e limites máximos admissíveis, é didaticamente interessante fazer um paralelo com os valores de comparação utilizados no monitoramento ambiental. Ao se monitorar o ambiente com a determinação da concentração do agente tóxico no ambiente, o critério de aceitabilidade são os valores máximos admissíveis. Para o ambiente ocupacional, esses valores recebem diferentes denominações como Limites de Exposição 
Ocupacional (LEO), Limites de Tolerância (LT), Threshold Limit Values (TLVs) ou Occupational Exposure Limits (OEL), e referem-se às concentrações das substâncias químicas dispersas no ar e representam condições às quais, acredita-se, que a maioria dos trabalhadores possa estar exposta, repetidamente, dia após dia, durante toda a vida do trabalhador, sem sofrer efeitos adversos à saúde (American Conference of Government Industrial Hygienists - ACGIH, 2005).

No caso do ar atmosférico externo, os valores máximos admissíveis são denominados Padrões de Qualidade do Ar e são os limites máximos para a concentração de um poluente na atmosfera, que garante a proteção da saúde, definidos em normas legais. Esses padrões são baseados em estudos científicos dos efeitos produzidos por poluentes específicos e são fixados em níveis que possam propiciar uma margem adequada de segurança (Brasil, 1990).

Os valores máximos admissíveis para poluentes no ambiente externo são mais baixos do que no ambiente ocupacional. Essa diferença deve-se a diferentes cenários de exposição a que os trabalhadores e a população geral estão submetidos, além das diferenças intrínsecas dos indivíduos a serem protegidos, tais como a presença de idosos e crianças na população geral. Assim, os trabalhadores e a população geral podem estar expostos a contaminantes liberados pela mesma fonte, porém, não se pode esquecer das características intrínsecas de cada tipo de exposição. Normalmente, as concentrações às quais os trabalhadores estão expostos são mais elevadas do que na exposição da população geral. Enquanto o tempo de exposição 
no ambiente ocupacional é restrito a 8 horas diárias, por 5 ou 6 dias semanais, no ambiente externo a população fica exposta 24 horas por dia ao agente tóxico.

Outra diferença entre as duas exposições é em relação ao agente tóxico. No ambiente ocupacional é comum a presença de uma ou mais substâncias conhecidas, pois estão relacionadas ao processo produtivo. Já na exposição ambiental, dependendo da área geográfica, várias substâncias e seus produtos de transformação podem estar presentes concomitantemente no ambiente, em concentrações baixas usualmente de difícil detecção. Assim, a avaliação da exposição a contaminantes ambientais bem como dos seus efeitos na população geral, deve ser realizada de maneira criteriosa utilizando todas as informações disponíveis, tanto toxicológicas e epidemiológicas como ambientais.

As normas de saúde ambiental são muito mais restritivas que as de saúde ocupacional. A diferença é justificada porque, além das razões já mencionadas, na comunidade encontram-se também grupos sensíveis, como idosos, enfermos, crianças e mulheres grávidas, enquanto que a população ocupacional, em geral, é composta por adultos com saúde suficientemente boa para trabalhar (Yassi e Kjellström, 2001).

$\mathrm{Na}$ biomonitorização $(\mathrm{BH})$, os resultados também devem ser comparados com referências apropriadas. Os valores de $\mathrm{BH}$ em trabalhadores devem ser comparados com os Limites Biológicos de Exposição. No Brasil, esse limite é denominado Índice Biológico Máximo Permitido (IBMP) e é equivalente ao Biological Exposure Indice (BEI) da 
ACGIH (American Conference of Governmental Industrial Hygienists). Segundo Della Rosa et al. (2008), esses limites devem ser vistos como níveis de advertência, propostos com base no conhecimento da relação dose-resposta, e não como valores que separam exposições seguras de exposições de risco. Para um número razoável de substâncias químicas de origem industrial, critérios derivados a partir de estudos de biomonitorização da exposição ocupacional estão bem estabelecidos, porém isso ainda não ocorre para a biomonitorização da exposição ambiental (Boogaard, 2007). $\mathrm{Na}$ área ocupacional, também é possível comparar os dados de $\mathrm{BH}$ em trabalhadores com uma população de referência tal como na $\mathrm{BH}$ ambiental, para dar subsídios às políticas de prevenção na área de saúde do trabalhador (Alessio, 1992 ; Apostoli, 1999).

No caso da biomonitorização da população geral, os valores utilizados para comparação podem ser tanto os valores limites toleráveis como os valores de referência. Alguns países vêm derivando os valores ou intervalos de referência na população geral a partir de estudos de biomonitorização humana com grande número de indivíduos, como os desenvolvidos na Alemanha (German Environmental Survey-GerES) e nos Estados Unidos (National Health and Nutrition Examination Survey-NHANES).

O GerES da Alemanha é um estudo de base populacional representativo para determinar a exposição da população geral a contaminantes ambientais. O primeiro estudo foi conduzido no período 1985-1986, seguido dos de 1990-1992, de 1998 e de 2003-2006. Este último teve como foco crianças e adolescentes. Um dos principais objetivos dos 
GerES é gerar, atualizar e avaliar dados representativos visando o acompanhamento de fatos relacionados à saúde ambiental e compilar informações a nível nacional. Cerca de 5 mil indivíduos participam a cada estudo. Os resultados também servem para estabelecer valores de referência, indicar tendências ao longo do tempo e diferenças regionais nos níveis de contaminantes e para identificar e quantificar as rotas de contaminação. Dessa maneira, o GerES possibilita planejar e avaliar as estratégias preventivas e de controle relacionadas à saúde e ambiente (UBA, 2006).

A Comissão de Biomonitoramento Humano da Alemanha também define alguns limites máximos toleráveis denominados valores de biomonitoramento humano - HBM (Human Biological Monitoring) para comparar com os dados obtidos na população geral. Os HBM são derivados de estudos toxicológicos e epidemiológicos e podem ser considerados limites biológicos de exposição. Dois níveis são definidos: HBM | e HBM II (Figura 1). O valor de HBM I representa a concentração da substância no material biológico humano abaixo da qual, de acordo com o conhecimento e julgamento da Comissão, não há risco de efeitos adversos à saúde. O HBM Il representa a concentração da substância no material biológico humano acima da qual há um aumento do risco de efeitos adversos à saúde nos indivíduos susceptíveis da população geral. O HBM I pode ser considerado um valor de alerta (do ponto de vista toxicológico), e conseqüentemente não há necessidade de intervenção, e o HBM II um nível de intervenção ou ação, com necessidade urgente de reduzir a exposição e fornecer tratamento 
médico individual. Valores entre HBM I e HBM II requerem confirmações que podem ser feitas através do aumento da freqüência de análises laboratoriais além de medidas para reduzir as fontes potenciais de exposição. O HBM I representa, portanto, um valor de controle ou de verificação (Ewers et al, 1999; Schulz et al., 2007a).

\begin{tabular}{|c|c|l|}
\hline Efeitos adversos à saúde & \multicolumn{1}{c|}{ Recomendação } \\
\hline HBM II & Possível & $\begin{array}{l}\text { - Tratamento médico } \\
\text { - Ação imediata para reduzir exposição }\end{array}$ \\
\hline HBM I & $\begin{array}{c}\text { Não se pode excluir com certeza } \\
\text { suficiente }\end{array}$ & $\begin{array}{l}\text { - Conferência dos resultados analíticos } \\
\text { - Indentificar fontes específicas de exposição } \\
\text { - Reduzir exposição para níveis adequados }\end{array}$ \\
$\begin{array}{c}\text { Não esperado à luz dos } \\
\text { conhecimentos atuais }\end{array}$ & \begin{tabular}{l} 
Não há necessidade da adoção de medidas \\
\hline
\end{tabular}
\end{tabular}

Figura 1 - Definição de valores HBM da Alemanha e recomendações FONTE: Schulz et al. 2007a

Até hoje, a Comissão de Biomonitoramento Humano da Alemanha derivou valores HBM para chumbo em sangue (Wilhelm et al., 2004), pentaclorofenol em soro e urina, cádmio na urina e mercúrio em sangue e urina (Schulz et al., 2007a).

Os VR são definidos pela mesma Comissão, como valores derivados estatisticamente que indicam a margem superior da exposição basal "background" para um dado poluente numa dada população em um tempo determinado. Eles podem ser usados para estimar a exposição basal ubíqua de indivíduos ou grupos da população. Devido a mudanças às quais as 
condições ambientais estão sujeitas, os valores de referência são continuamente checados e atualizados (Schulz et al., 2007a).

Deve-se reforçar que os VR são derivados estatisticamente e não representam valores orientadores baseados em efeitos na saúde. Assim, se a concentração de um poluente no sangue ou urina excede o VR, isto não significa, necessariamente, que há um aumento do risco à saúde. Por outro lado, não se exclui um risco à saúde somente porque a concentração medida de um poluente está abaixo do VR (Schulz et al., 2007a).

Até hoje, a Comissão de Biomonitoramento Humano da Alemanha já estabeleceu VR para arsênio, cádmio, chumbo, níquel, mercúrio, platina e pentaclorofenol na urina ou/e sangue, e para metabólitos de DEHP - Di (2-etilhexil)ftalato - (5 oxo-MEHP, 5OH-MEHP), de organofosforados (DMP, DMTP, DEP), de hidrocarbonetos aromáticos policíclicos (1-hidroxipireno), de piretróide (cis- $\mathrm{Cl}_{2} \mathrm{CA}$, trans- $\mathrm{Cl}_{2} \mathrm{CA}$, 3-PBA) na urina, bifenilas policloradas (PCBs), para $\beta$-hexaclorocicloexano $(\beta-\mathrm{HCH})$, hexaclorobenzeno $(\mathrm{HCB})$ e diclorodifeniltricloroetano (DDE) em sangue e em leite humano para alguns PCBs e praguicidas organoclorados $(\beta-\mathrm{HCH}, \mathrm{HCB}$, total DDT) (Schulz et al., 2007a).

Outros países como República Checa, Eslovênia e Itália também realizam estudos populacionais visando determinar valores de referência. No Brasil, Paoliello et al. (2001), estabeleceram valores de referência para chumbo em uma população não exposta ocupacionalmente da cidade de Londrina. 
Assim, o VR é um valor derivado de estudos populacionais que determina a concentração do analito de interesse em fluidos (ou outros materiais biológicos) em indivíduos de uma população, a partir da análise estatística dos valores medidos. É utilizado para determinar o limite superior da exposição basal da população geral, num determinado momento. O VR não representa, portanto, um critério de normalidade para uma análise toxicológica, e deve ser usado para identificar indivíduos com nível de exposição ambiental aumentado (em relação à exposição basal) à determinada substância. Os VR não são derivados a partir de dados de saúde ou toxicológicos, como são os limites biológicos de exposição (Ewers et al., 1999; Schulz et al., 2007a). Em alguns casos é necessário interpretar os VR juntamente com os valores considerados limites para proteção da saúde da população de interesse (trabalhadores ou população geral) (Apostoli, 1999). Ressalta-se mais uma vez que os valores máximos permitidos definidos para o trabalhador, não são os mesmos que devem ser adotados para a população geral como já discutido anteriormente.

O cálculo do VR é feito a partir de uma amostra, oriunda da população de referência. Esta exclui os indivíduos expostos ao xenobiótico devido a situações de contaminação ambiental e/ou de trabalho. Devem ser definidos diferentes VR para subgrupos da população, os quais podem apresentar diferentes níveis de exposição e de absorção, metabolização e excreção dos toxicantes, como no caso de homens e mulheres, crianças, adolescentes e adultos. De acordo com Ewers et al. (1999), os valores de referência devem ser revisados conforme ocorram alterações nos níveis basais da população 
geral, ou seja, eles deverão ser revistos periodicamente sempre com base nos resultados de estudos recentes (Ewers et al., 1999; Schulz et al., 2007a). No item 2.1 será detalhada a metodologia de derivação de VR.

\section{Algumas experiências de biomonitorização humana}

$\mathrm{Na}$ literatura encontram-se muitos estudos de biomonitorização de populações para avaliação da exposição a contaminantes químicos ambientais, porém poucos deles têm por objetivo derivar valores de referência. Os principais estudos, cuja abrangência demográfica faz com que tenham uma maior representatividade são o National Health and Nutrition Examination Survey (NHANES), realizado pelo Centers for Disease Control and Prevention (CDC) nos EUA, o German Environmental Survey (GeES) da Alemanha e o Environmental Health Monitoring System in the Czech Republic, estudo nacional da República Checa.

O National Health and Nutrition Examination Survey (NHANES) é um inquérito nacional dos Estados Unidos, que coleta dados sobre o estado de saúde e nutricional de adultos e crianças no país. O NHANES, além de obter informações sobre fatores relacionados à saúde, faz exames físicos e coleta amostras da população para testes de laboratório, incluindo análise de contaminantes ambientais. Iniciado em 1999, o NHANES é um estudo populacional contínuo, a população americana é amostrada anualmente, e os dados são publicados a cada dois anos. O plano de amostragem é 
complexo para poder selecionar uma amostra representativa da população civil não institucionalizada dos EUA (CDC, 2005a).

O German Environmental Surveys (GerES), estudo populacional da Alemanha, realizado desde a década de 80 tem por principal objetivo analisar e documentar a extensão, distribuição e os determinantes da exposição aos poluentes ambientais da população geral da Alemanha. Os três principais instrumentos de pesquisa do GerES são biomonitoramento humano (HBM), monitoramento do ambiente doméstico, e a coleta de informações por meio de questionário sobre as vias de exposição e condições de vida da população (Schulz et al., 2007b).

Já a República Checa tem o Environmental Health Monitoring System que coleta, processa e avalia os dados sobre poluição ambiental e seus efeitos na saúde da população em 30 cidades inclusive a capital Praga. É composto por subsistemas que estão sendo conduzidos desde 1994. Em 2007, o Sistema de Monitoramento foi formado por oito subsistemas (projetos) relacionados à avaliação de riscos e efeitos à saúde decorrentes da poluição do ar, poluição da água de consumo, ruído, dieta, ambiente ocupacional e poluição de solo urbano, outro de biomonitoramento humano, além do de indicadores de saúde (Puklová, 2008).

Com as informações obtidas nesses estudos, é possível criar séries históricas que propiciem a avaliação sistemática dessas para identificar tendências ao longo do tempo ou sazonais que subsidiem recomendações e propostas de medidas a serem adotadas nas áreas de saúde pública e meio ambiente. 
$\mathrm{A} B \mathrm{H}$ vem sendo utilizada na área da Saúde Ambiental fornecendo subsídios consistentes para decisões em saúde, porém há necessidade de se buscar mais informações sobre os efeitos na saúde dos diferentes contaminantes ambientais e melhorar a interpretação dos dados de biomonitoramento. Existe uma necessidade urgente de se definir valores limite e valores de referência adequados para a população brasileira, para que possam ser utilizados nos estudos de $\mathrm{BH}$ visando o diagnóstico ambiental e avaliação de risco à saúde. A utilização de valores de referência e valores limites, sem levar em conta o entendimento amplo sobre os mecanismos de ação do toxicante (modelo toxicocinético/dinâmico), tipo de população exposta e condições de exposição específicas, podem conduzir a conclusões equivocadas na estimativa do risco da exposição aos contaminantes.

Essa necessidade é percebida quando da utilização de biomarcadores em estudos que visam avaliar a qualidade ambiental ou estimar a exposição em estudos de avaliação de risco. No Brasil, em casos, por exemplo, de áreas contaminadas, os dados obtidos nesses estudos são comparados com VR de outros países, normalmente com os dos EUA e Alemanha. Essas comparações devem ser feitas com cuidado, pois os VR são específicos para as características da população para os quais foram derivados e do ambiente físico onde se encontra a população estudada, pois as substâncias de interesse podem ser de origem tanto antrópica como natural.

Acompanhando a tendência mundial, a $\mathrm{BH}$ está se configurando também em um instrumento para decisões na área de saúde em nosso país. 
Em 2006, iniciou-se o projeto piloto do I Inquérito Nacional de Populações Expostas a Substâncias Químicas elaborado pela Secretaria de Vigilância em Saúde - SVS do Ministério da Saúde, por meio da Coordenação Geral de Vigilância em Saúde Ambiental - CGVAM. O projeto tem como objetivo avaliar o nível da exposição humana a substâncias químicas de interesse à Saúde Pública e a identificação das populações sob risco de exposição aumentada. Deste modo, poderão ser subsidiadas ações de vigilância cada vez mais efetivas, tendo em vista a possibilidade de identificação de prioridades quanto às substâncias freqüentemente encontradas e as características das populações submetidas a tais exposições.

Em decorrência do uso cada vez maior da $\mathrm{BH}$, necessita-se a definição de VR para os principais contaminantes de importância para nosso país. A escolha dos contaminantes a serem avaliados deve ser feita baseada não somente na ocorrência destes na região e na sua toxicidade, mas também na disponibilidade de biomarcadores para esses contaminantes e a sua exeqüibilidade analítica.

A cidade de São Paulo e imediações, pelo alto nível de industrialização, apresentam várias áreas decretadas contaminadas por resíduos de origem industrial. Segundo levantamento até novembro de 2007, realizado pela Companhia de Tecnologia de Saneamento Ambiental Cetesb, no estado de São Paulo foram contabilizadas 2272 áreas contaminadas, sendo 1185 localizadas na Região Metropolitana de São Paulo (RMSP). Os metais estão entre os principais grupos de contaminantes encontrados nas áreas contaminadas, quais sejam: solventes aromáticos, 
combustíveis líquidos, hidrocarbonetos policíclicos aromáticos (HPAs), metais e solventes halogenados (Cetesb, 2007a).

Os metais são, entre os poluentes tóxicos, caso único em que todos os elementos ocorrem naturalmente na biosfera. São contaminantes ambientais ubíquos, podendo ser encontrados no solo, água e alimentos. Por essa razão, independentemente do seu uso seguro em processos industriais e em produtos de consumo, alguma exposição humana aos metais é inevitável. Uma característica especial desses metais é sua tendência de acumular-se nos tecidos biológicos e, em geral, a sua eliminação é lenta. Essa mesma característica ocorre com os metais no ambiente. Uma vez nesse sistema, os metais mantêm-se por longo período e a exposição da população a esses compostos, mesmo que a baixas concentrações pode resultar, a longo prazo, em efeitos prejudiciais à saúde como a diminuição de QI em crianças expostas ao chumbo. Outro efeito crônico importante é a carcinogênese, e diversos metais foram classificados como carcinógenos humanos. A toxicologia dos metais sempre esteve associada a eventos de curto prazo, quando os efeitos são agudos, bem evidentes. Nos dias atuais, observam-se ocorrências a médio e longo prazo, e as relações causa-efeito são pouco evidentes e quase sempre subclínicas (Liu et al., 2008). Por isso, vários estudos vêm sendo desenvolvidos para estimar a exposição ambiental e identificar alterações precoces na saúde da população.

Apesar de o chumbo, cádmio e mercúrio estarem naturalmente presentes no ambiente, as exposições humanas mais importantes são 
decorrentes da atividade antrópica (McKelvey et al., 2007). Esses metais são importantes contaminantes ambientais devido aos sérios efeitos que causam na saúde humana e dos organismos em geral.

Assim, o presente estudo foi concebido com o propósito de propor valores de referência para chumbo $(\mathrm{Pb})$, cádmio $(\mathrm{Cd})$ e mercúrio $(\mathrm{Hg})$ para a população adulta da Região Metropolitana de São Paulo. 


\section{REVI SÃO DA LITERATURA}

\subsection{Metodologia de derivação de valor de referência}

A conceituação e os aspectos envolvidos na determinação e aplicação de VR foram extensamente estudadas por um comitê de especialistas da International Federation of Clinical Chemistry (IFCC) (Apostoli, 1999) que com o propósito de padronizar o estabelecimento e publicação de valores de referência biológicos, publicou uma série de recomendações sobre a teoria de valores de referência, entre eles: Conceito de valores de referência (Solberg, 1987a); seleção de indivíduos para produção de valores de referência (PetitClerc e Solberg, 1987); tratamento estatístico dos valores referência coletados Determinação dos limites de referência (Solberg, 1987b); e apresentação dos valores observados relacionados aos valores de referência (Dybkaer e Solberg, 1987).

As recomendações da IFCC descrevem os princípios e procedimentos para a seleção de populações de referência e derivação de valores de referência. Apesar dessa metodologia ter sido concebida para aplicação no campo da química clínica e hematologia, em grande parte, pode ser seguida para derivação de VR para biomarcadores de exposição ambiental e ocupacional (Poulsen et al., 1997). 
Os cuidados na escolha da população de referência para biomarcadores devem ser os mesmos recomendados para química clínica. Normalmente a formação dos grupos de referência é feita por meio de critérios de exclusão/inclusão e de estratificação. Enquanto na química clínica o principal fator de exclusão é o estado de saúde, na toxicologia ambiental é a exposição anormal aos xenobióticos. Por exemplo, a contaminação natural ou antropogênica pode influenciar os VR para As, Hg, $\mathrm{Pb}$, benzeno ou praguicidas. Outras fontes de variabilidade são alimento, água, fumo e consumo de álcool, que podem interferir nos níveis de analitos como Cd, As, Hg, 1-hidroxipireno e ácido hipúrico (Apostoli, 1999). No caso dos metais, além das condições ambientais, devem ser consideradas como critério de exclusão as alterações funcionais do organismo que podem estar afetando a toxicocinética desses contaminantes (Apostoli, 1992).

Segundo a IFCC (Solberg, 1987a), os valores de referência só são significativos quando os indivíduos e métodos utilizados para sua derivação são descritos adequadamente. Sendo essencial especificar: a) os critérios de inclusão ou exclusão usados para definir a população de referência; b) a caracterização dos subgrupos quanto à idade, sexo, etnia, fatores genéticos e sócio-econômicos, etc; c) as condições fisiológicas e ambientais sob as quais a população de referência foi estudada e as amostras foram coletadas (período de coleta, ingestão de alimentos e medicamentos, fumo, gravidez ou estágio do ciclo menstrual); d) tipo de material coletado, manuseio e armazenamento das amostras; e) método analítico utilizado, inclusive seus limites de detecção, especificidade, precisão e exatidão e f) método estatístico usado para estimar os limites de referência. 


\subsubsection{Seleção dos indivíduos para a produção de valores de referência}

A IFCC discute no seu documento sobre seleção dos indivíduos para produção de valores de referência, que a utilização de grupos saudáveis como referência, deve ser avaliada com cautela. Tradicionalmente, os valores de referência utilizados em química clínica são de indivíduos supostamente saudáveis. Entretanto, saúde não é uma condição bem definida e sim um estado relativo, pois é conceitualmente diferente em diferentes países, no mesmo país em épocas diferentes, e no mesmo indivíduo em idades diferentes. Os valores de referência têm ampla utilização, são usados para avaliar o estado de saúde de indivíduos e populações, para identificar pessoas sob risco de adquirir doença, para ajudar nas decisões em clínica médica, e para diversos fins científicos. Dessa maneira, o critério de saúde na seleção da população de referência deve ser orientado pelo objetivo da pesquisa laboratorial, portanto, nem sempre os indivíduos de referência são pessoas saudáveis (PetitClerc e Solberg, 1987).

Na Figura 2, estão esquematizados dois tipos de seleção possíveis de populações ou indivíduos. "A posteriori" ou retrospectiva, é a seleção de indivíduos a partir de uma amostra grande da população obtida aleatoriamente ou não, seguida pela estratificação ou exclusão, de acordo com as características do grupo da amostra de referência. Esse tipo de seleção é ideal para investigação de critérios de exclusão e de estratificação, já que os grupos amostrados representam os principais elementos da população geral, por exemplo, população rural e urbana, classes sócioeconômicas, grupos étnicos, etc. "A priori” ou prospectiva, é a seleção de 
indivíduos da população geral usando critérios de exclusão e de estratificação estabelecidos em estudos prévios na mesma população ou obtidos da literatura. A seleção a priori é muito mais conveniente, mas requer critérios conhecidos ou arbitrariamente estabelecidos. Quanto mais dados disponíveis na literatura, mais favorecido é esse tipo de seleção (PetitClerc e Solberg, 1987). Para ambos os tipos de seleção, o tamanho dos grupos amostrais é determinado pela natureza dos critérios de exclusão e do número de critérios de estratificação a serem aplicados. A seleção a posteriori parece ser melhor para produção de valores de referência de indivíduos saudáveis, mas a seleção a priori, pode ser aplicada a todas as situações.

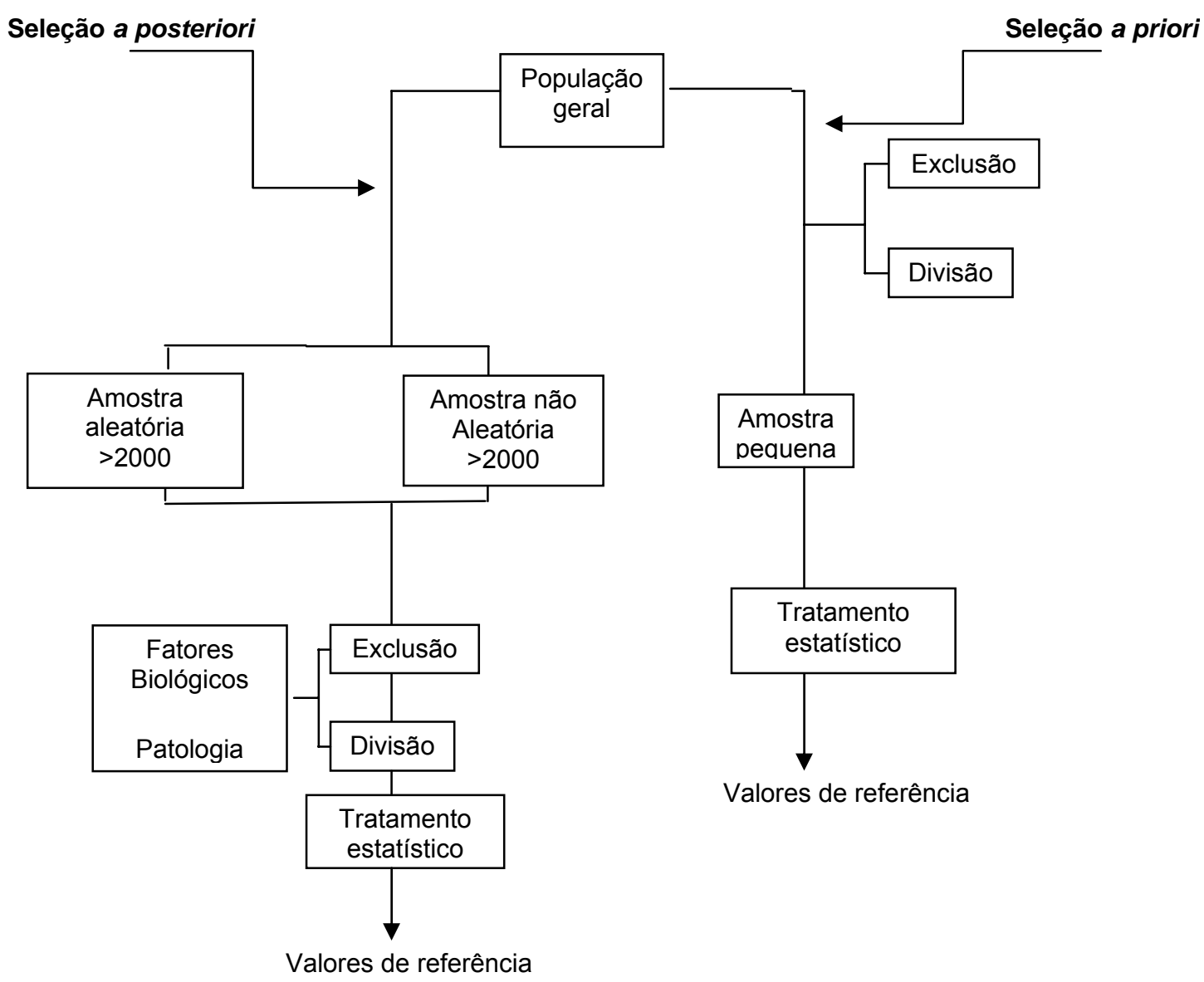

Figura 2 - Os dois tipos de seleção de indivíduos para derivar valores de referência, a posteriori e a priori. FONTE: PetitClerc e Solberg, 1987 
Muitos fatores contribuem para a variabilidade biológica e devem fazer parte dos critérios de exclusão e estratificação dos indivíduos de referência. Também, o propósito da utilização dos valores de referência é que vai determinar os critérios de exclusão que serão aplicados. Por exemplo, os estudos epidemiológicos e os programas de medicina preventiva requerem valores de referência obtidos a partir de indivíduos saudáveis, onde são excluídos aqueles indivíduos que sofrem de doenças sistêmicas e distúrbios fisiopatológicos (PetitClerc e Solberg, 1987).

Assim, dependendo da intenção do uso dos VR e no tipo quantitativo da medida, alguns ou todos os seguintes critérios de exclusão devem ser aplicados: estados fisiopatológicos, uso de agentes farmacologicamente ativos, estados fisiológicos alterados (gravidez, exercício físico, distúrbios mentais e psicológicos, ingestão de alimentos antes da coleta da amostra de sangue) e outros (obesidade, hipertensão). No entanto, em alguns casos, esses são usados como critérios de estratificação ou classificação para obter VR de grupos amostrais de referência bem identificados como consumidores de bebida alcoólica, fumantes, mulheres que usam contraceptivos, mulheres grávidas, indivíduos obesos, etc. (PetitClerc e Solberg, 1987).

A necessidade em subdividir os grupos de referência pode diferir com as quantidades medidas e os usos dos VR. A estratificação deve ser limitada aos VR que apresentam diferenças significativas. Por exemplo, a idade não deve ser necessariamente categorizada por intervalos iguais, e sim pela variação das quantidades medidas conforme a idade. Esses intervalos devem ser menores em períodos como a puberdade e a menopausa. Para 
categorizar crianças, a idade óssea, altura e massa corpórea são melhores indicadores do que a idade (PetitClerc e Solberg, 1987).

Em alguns casos, a estratificação por origem étnica, área geográfica ou pigmentação da pele, pode ser de utilidade em algumas medidas; em outras, os marcadores genéticos como grupo sangüíneo e antígenos de compatibilidade histológica podem ser mais apropriados. A presença ou ausência fenotípica de proteínas plasmáticas e de enzimas tissulares pode ser útil na obtenção de grupos amostrais de referência homogêneos (por exemplo, $\alpha_{1}$-antitripsina, apolipoproteína $B$, fenilalanina hidroxilase) (PetitClerc e Solberg, 1987).

Também, a adaptação dos indivíduos ao seu ambiente ecológico como ao seu estado sócio-econômico pode ser a principal fonte das diferenças, por exemplo, a concentração de colesterol-S de asiáticos e imunoglobulinas-S de negros africanos antes e após emigração para Europa ou América (Wilding e Bailey, 1979* apud PetitClerc e Solberg, 1987).

Em resumo, a produção de VR a partir de qualquer população ou indivíduos requer seleção apropriada e geralmente estratificação, que deve ser feita por meio de descrição cuidadosa das características dos indivíduos de referência e pela aplicação de critérios estabelecidos claramente (PetitClerc e Solberg, 1987).

\footnotetext{
* Wilding P; Bailey A. The normal range. In: Williams DL; Nunn RF. Marks V. eds. Scientific Foundations of Clinical Biochemistry, Vol. 1.London: Heinemann Medical Books Ltd, 1979; 451-459.
} 


\subsubsection{Tamanho da amostra, determinação dos valores de referência e apresentação dos Valores ou Intervalos de Referência}

O cálculo do tamanho da amostra varia entre os estudos de derivação de VR. Para propor VR para chumbo em sangue na população do município de Londrina, Paolielo et al. (1997) dimensionaram o tamanho da amostra considerando o número de habitantes da região acima de 15 anos e a média e desvio-padrão das plumbemias obtidas no pré-teste. A população estudada foi formada por voluntários contatados por meio do Conselho Regional de Saúde e Associações de moradores da região. A International Federation of Clinical Chemistry (IFCC) recomenda que o número de valores para cada subclasse deva ser de pelo menos 120 indivíduos (Solberg, 1987b). Em geral, a distribuição das medidas biológicas não segue o modelo Gaussiano e por essa razão, a IFCC recomenda a utilização de intervalos não-paramétricos que compreendem os valores entre os percentis 2,5 e 97,5. Ao estimar esses intervalos usando 120 observações ou mais, são obtidos intervalos de confiança mais estreitos para os percentis, o que dá maior segurança em considerar um valor medido que esteja acima do limite superior do intervalo de confiança para o P97,5 como um valor alto, incomum (Poulsen et al., 1997). Ainda, a IFCC e vários autores concordam que a população de referência não pode ser determinada quantitativamente, uma vez que o número total de indivíduos de referência ou não expostos é desconhecido. Dessa forma, a população de referência seria definida como uma entidade hipotética e o cálculo do tamanho de sua amostra, na prática pretende apenas 
garantir um número grande suficiente para tornar a amostra representativa (Solberg, 1987a; Apostoli, 1999). Cabe destacar que o grupo amostral pode ser oriundo de um subgrupo da população de referência, e até mesmo ser formado por apenas um membro, por exemplo, um indivíduo pode ser referência de si mesmo ou de outro indivíduo (Solberg, 1987a).

Os valores determinados no grupo de referência são comumente, por conveniência, condensados em um intervalo definido por dois limites de referência. Os procedimentos utilizados para derivar esses intervalos variam desde técnicas estatísticas complexas à simples estimativa intuitiva a partir dos dados disponíveis (Solberg, 1987a).

Visando a utilização de amostras pequenas, Hansen et al. (2007) propuseram um método para estimar valores de referência que utiliza um modelo de componentes da variância que leva em conta vários fatores de confusão como gênero, idade, IMC (Índice de Massa Corpórea), fumo, menopausa, entre outros. Este método tem sua principal aplicação em saúde ocupacional, pois propicia calcular intervalos de referência para grupos específicos, p.ex. fumantes versus não fumantes.

Estudos populacionais feitos nos Estados Unidos, Alemanha, Itália e outros países da Europa determinaram concentrações de substâncias tóxicas em fluidos ou tecidos da população geral e apresentaram como valores de referência a média mais ou menos 2 desvios-padrão para distribuição normal, ou o valor dos percentis 90 ou 95 para qualquer tipo de distribuição, sendo o intervalo de 95\% de confiança (IC95\%) desses valores, o intervalo de referência (U.S.EPA, 2002a; Ewers et al., 1999; Minoia et al., 1990; Kucera et al. 1995; UBA, 2008; Poulsen et al., 1997). 
Os intervalos de referência definidos pelos percentis são os mais usados, eles são facilmente estimados tanto por métodos estatísticos paramétricos como não-paramétricos. A IFCC estabelece como intervalos de referência os valores entre o percentis 2,5 e 97,5 e seus respectivos limites de confiança não-paramétrico de 90\%. Esses limites cortam a fração 0,025 dos valores que se encontram em cada extremidade da distribuição, isto é, o intervalo de referência deve conter a fração 0,95 central (ou 95\%) da distribuição. Em alguns casos, outros tamanhos ou posição assimétrica do intervalo de referência podem ser mais apropriados (Solberg, 1987b).

Muitas vezes, o número de valores disponível para a determinação dos intervalos de referência é limitado. A imprecisão da estimativa dos percentis aumenta com a diminuição do tamanho da amostra, fornecendo intervalos de confiança mais amplos. Nota-se que um percentil $\alpha$ e percentis (1- $\alpha)$ só podem ser estimados se $\alpha$ estiver bem acima de $1 / N$, sendo $N$ o tamanho da amostra. Portanto, para determinar os percentis 2,5 e 97,5, são necessários pelo menos 40 observações. Com menos de 120 observações, não é possível obter intervalos de confiança de $90 \%$ bicaudal para os percentis 2,5 ou 97,5 . Para esses casos, uma alternativa é reduzir o nível de confiança, por exemplo, intervalos de confiança de $70 \%$ podem ser calculados com 75 dados (Reed et al., 1971). Para se avaliar se a precisão dos limites de referência é suficiente para o uso proposto, os intervalos de confiança dos percentis devem sempre ser levados em conta. Quando não se dispõe de número grande de dados e a estimativa precisa dos percentis é impossível, uma amostra pequena pode servir como orientação para fins clínicos, nesse caso todos os valores devem ser apresentados listados em ordem crescente (Solberg, 1987b). 
Outro método para calcular intervalo de referência foi proposto por uma Comissão de Toxicologia da International Union of Pure and Applied Chemistry (IUPAC) em documento publicado em 1997, onde também ratifica a metodologia da IFCC para a derivação de VR para serem utilizados em química clínica, saúde ocupacional e ambiental. A IUPAC recomenda a utilização do intervalo de cobertura que abrange em média 95\% da distribuição e a probabilidade é de pelo menos $95 \%$ ou $90 \%$ (quando se tem poucos dados) que o intervalo esteja entre $(0,95-\alpha)$ e $(0,95+\alpha)$ da distribuição. A vantagem dessa metodologia sobre a da IFCC é a possibilidade de se calcular o intervalo, com estimativa de incerteza, mesmo quando se dispõe de menos de 120 observações (Poulsen et al., 1997). Usando essa metodologia, a Agência Ambiental Federal da Alemanha (UBA) deriva os seus VR, que se encontram dentro do intervalo de confiança $95 \%$ do P95 da distribuição dos valores observados nas populações estudadas (GerES) (UBA, 2008).

A Figura 3 mostra o procedimento recomendado pela IFCC (Solberg, 1987b) para a determinação do intervalo de referência após a coleta dos dados. Os dados devem ser estratificados (de acordo com sexo, idade, etc) para reduzir a variação. Quanto menor for a variação intra-classes, mais precisos e mais sensíveis serão os intervalos de referência. Diferenças significativas entre grupos verificadas por testes estatísticos (Teste $t$ de Student, análise de variância, etc.) ou intra-classe (Teste F de Fisher, Teste de Barlett, etc.) indicam a necessidade de estratificação. Deve-se analisar a distribuição dos dados (histogramas) para se verificar assimetria, curtose 
(achatamento), valores extremos e bi ou poli- modalidades (número de picos). A presença de bi/poli-modalidades, assimetria excessiva ou outras peculiaridades da distribuição indicam que há mistura, podendo ser necessário reavaliar os critérios de inclusão e exclusão usados para definir a população de referência. Ou ainda, pode-se estratificar o grupo amostral de acordo com sexo, idade, e/ou outros fatores relevantes. A inspeção visual da distribuição auxilia na escolha correta dos métodos estatísticos bem como sua interpretação adequada. Dados fora da distribuição podem ser considerados "outliers", podendo ser descartados. Mas antes de descartar os "outliers", deve-se reavaliar o caso desde o critério de inclusão do indivíduo até a análise e coleta da amostra (Solberg, 1987b).

Quando se tem um número suficiente de dados, deve-se optar por método paramétrico ou não-paramétrico para estimar os percentis. Para amostras pequenas, a estimativa intuitiva ou mais ou menos arbitrária dos limites de referência pode ser a única possibilidade. Também é o caso quando a aplicação de métodos estatísticos é inapropriada, por exemplo, em algumas situações onde são empregados os testes qualitativos. Não há regras definidas para a estimativa intuitiva dos limites de referência, são definidas caso a caso (Solberg, 1987b).

Para qualquer tipo de distribuição o método não-paramétrico pode ser usado para definir os intervalos de referência. Já a opção pelo método paramétrico tem que ser feita em até três etapas. Se a distribuição dos dados é Gaussiana, estimam-se os percentis diretamente. Do contrário, tenta-se a transformação dos dados ou escolhe-se o método não- 
paramétrico. Após a transformação dos dados que pode ser logarítmica ou por raiz quadrada, testa-se novamente a distribuição, agora dos dados transformados, se for Gaussiana ou muito próxima, estimam-se os percentis usando os dados transformados pelo método paramétrico. Se mesmo com a transformação, a distribuição não for Gaussiana, utilizam-se os valores originais (não-transformados) e emprega-se o método não-paramétrico (Figura 3) (Solberg, 1987b).

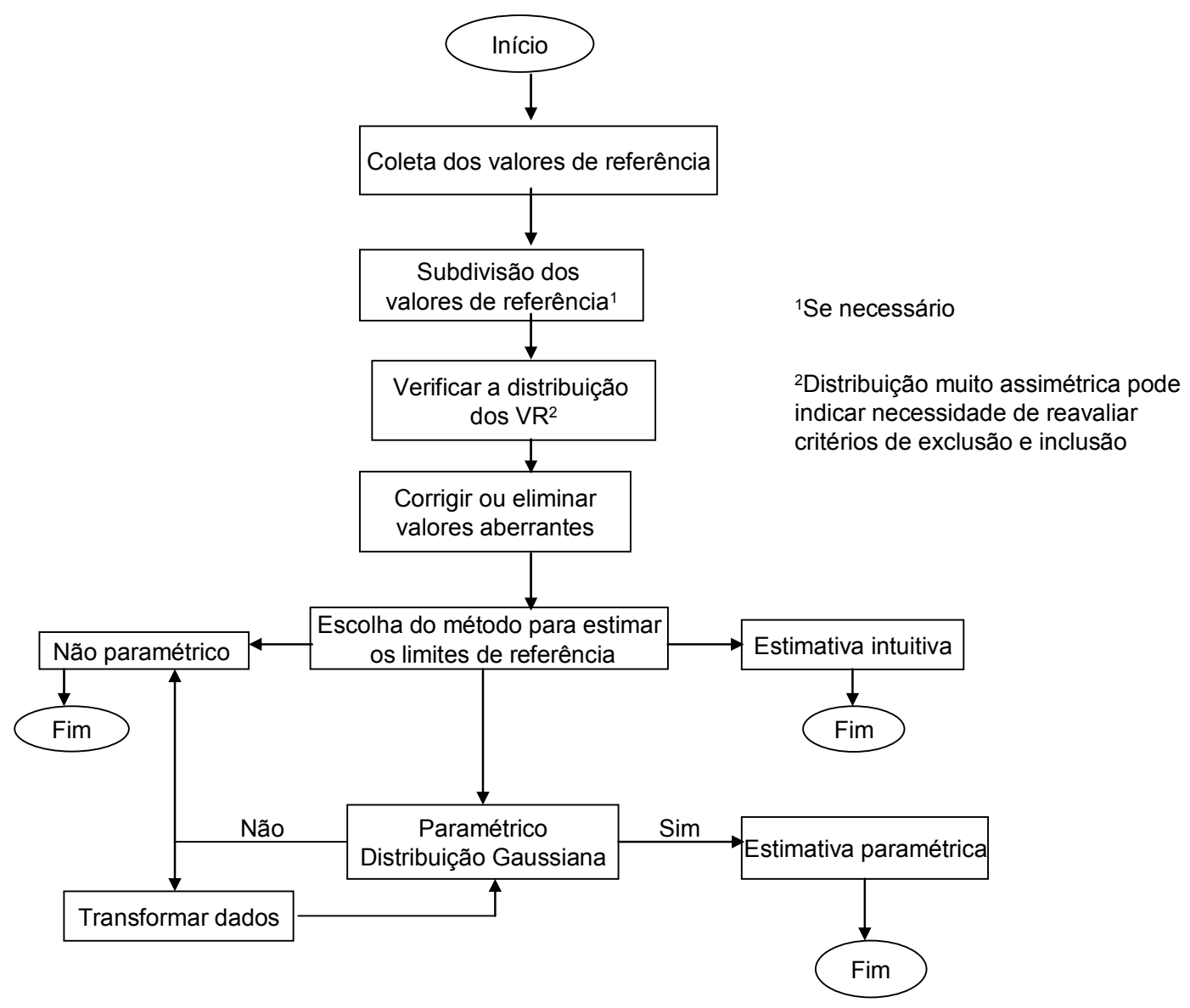

Figura 3 - Procedimento para estimar limites de referência. FONTE: Solberg, 1987b 
A apresentação dos valores e intervalos de referência deve ser feita conforme descrito abaixo, segundo a IFCC (Dybkaer e Solberg, 1987) e a IUPAC (Poulsen et al., 1997):

a) Número de valores $(n)$ utilizados para estimar os VR

b) Distribuição dos valores utilizados

Média, Mediana, Teste para normalidade (tipo e resultado probabilidade, $P$ ), se não normal, citar o método de transformação, mostrar o teste de normalidade após a transformação $(P)$

c) Intervalos

- Recomendação IFCC $(n \geq 120)$ :

Intervalo de referência 0,95 não-paramétrico (entre os percentis $2,5$ e 97,5$)$

- Recomendação IUPAC:

Intervalo de cobertura 0,95 não-paramétrico com incerteza do intervalo a nível de confiança de $95 \%$. 


\subsection{Toxicologia dos metais}

O propósito deste item é fornecer um resumo da Toxicologia de cada metal, enfocando a toxicocinética, efeitos na saúde relacionados a exposição ambiental, bem como as possíveis rotas de exposição da população geral.

\subsubsection{Toxicologia do chumbo}

\section{Identificação, ocorrência e usos}

O chumbo é um metal pesado de coloração cinza-azulado resistente à corrosão, com baixo ponto de fusão e que ocorre naturalmente na crosta terrestre. No entanto, ele raramente é encontrado na forma de metal, geralmente está combinado com dois ou mais elementos formando os compostos de chumbo. É liberado no ambiente a partir de fontes naturais que incluem emissões vulcânicas, poeira transportada pelo vento e erosão, e por atividade antropogênica, sendo esta última, a principal responsável pela alta concentração de chumbo encontrada no ambiente. $\mathrm{O}$ aumento dos níveis ambientais de chumbo ocorreu principalmente com o uso de gasolina aditivada com composto desse metal. Também é usado como pigmento em tintas e cerâmica esmaltada, e em alguns tipos de tubulações. A emissão de chumbo no ar deve-se à mineração do chumbo e de outros metais, fábricas que o utilizam em seus processos (p.ex. reciclagem de bateria de carros), e à queima de carvão vegetal, petróleo ou lixo (Agency for Toxic Substances and Disease Registry-ATSDR, 2007). 
Aproximadamente metade das 300 milhões toneladas de chumbo produzidas ao longo da história persiste como contaminante no solo, água, ar e sedimento. Devido a essa persistência, o chumbo ambiental é considerado um problema de saúde pública, mesmo com decréscimo de sua utilização (WHO, 1995). Estudos epidemiológicos e experimentais vêm demonstrando que crianças podem desenvolver efeitos tóxicos decorrentes de exposição a baixas concentrações de chumbo (Wilhelm et al., 2002; CDC, 2005b; Jusko et al., 2008).

A maior parte do chumbo liberado para o ambiente localiza-se próxima à fonte de emissão, porém, algumas partículas de pequeno diâmetro $(<2 \mu \mathrm{m})$ são transportadas por longas distâncias, podendo ser encontradas em locais muito afastados da fonte de emissão, como em geleiras. A poeira de chumbo contribui para a exposição da população devido à contaminação ambiental e de alimentos (WHO, 1995), a Figura 4 apresenta as diversas fontes possíveis de exposição ao chumbo. 


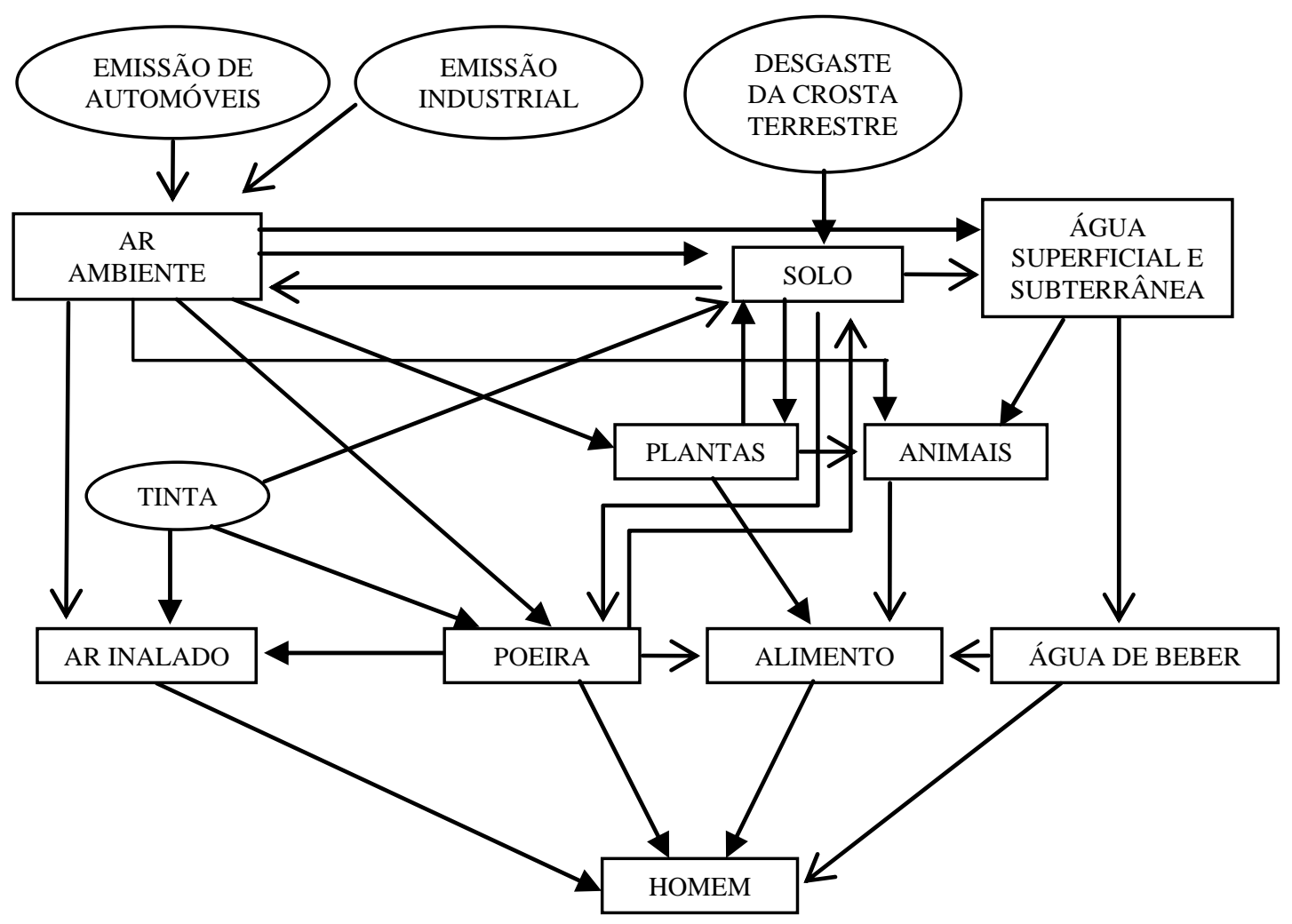

Figura 4 - Rotas ambientais que contribuem para a exposição humana ao chumbo. FONTE: WHO, 1995

\section{Toxicocinética}

Para a população geral, a exposição ao chumbo ocorre principalmente por via oral. Alguns fatores como hábito de fumar, local de moradia, ocupação, entre outros, podem contribuir significativamente para a exposição por inalação de poeiras contendo o metal. Para crianças mais novas, entre 4 e 5 meses de idade, a exposição pela água, ar e leite é muito importante. Para crianças mais velhas, a maior via de exposição é pela poeira e solo contaminados (ATSDR, 1999a; WHO, 1995). 
$\mathrm{Na}$ exposição principalmente pelas vias digestiva e inalatória, uma parte do chumbo é absorvida e distribuída a vários compartimentos do corpo de onde é eliminada em taxas variáveis. Genericamente, esses compartimentos podem ser divididos em tecidos moles e esquelético. Existe um intercâmbio entre o chumbo presente na corrente sangüínea e esses dois compartimentos. Estudos mais recentes indicam que o chumbo nos ossos é uma fonte do metal no sangue, mesmo após anos da exposição, e também de exposição do feto durante a gestação. A contribuição do chumbo acumulado nos ossos para os níveis sangüíneos varia conforme a duração e intensidade da exposição, idade e estados fisiológicos (estado nutricional, gravidez, menopausa) (U.S.EPA, 2006).

Os níveis de chumbo em sangue são um indicador do metal circulante. Esse biomarcador reflete as variações na exposição externa recente bem como do chumbo que foi mobilizado dos tecidos onde se acumula, ossos principalmente. Os níveis de $\mathrm{Pb}$ na tíbia e patela dão uma indicação da dose acumulada por décadas, pois correspondem ao maior estoque de $\mathrm{Pb}$ no corpo que pode ser disponibilizado para o sangue. Mais recentemente, a medida de $\mathrm{Pb}$ no tecido ósseo tem sido feita por técnica não invasiva, por instrumentação de fluorescência de raio-x. Esses dois biomarcadores de exposição juntos, $\mathrm{Pb}$ em sangue e nos ossos, fornecem as melhores ferramentas para avaliar exposição recente e cumulativa do metal em estudos epidemiológicos. Embora o $\mathrm{Pb}$ em sangue também esteja em equilíbrio com os estoques do metal dos ossos, a sua variabilidade é devida principalmente, a mudanças nos níveis de exposição externa (Hu et al., 2007). 
O chumbo inorgânico presente no ar encontra-se aderido ao material particulado. Assim, a absorção do chumbo depositado no trato respiratório vai depender tanto do tamanho da partícula e solubilidade, como pela característica da região do trato respiratório, onde o particulado é depositado. Partículas finas $(<1 \mu \mathrm{m})$ depositadas nas regiões bronquiolar e alveolar podem ser absorvidas após a dissolução extracelular ou ser ingeridas por fagócitos e transportadas. Partículas maiores $(>2,5 \mu \mathrm{m})$ são depositadas principalmente nas vias aéreas ciliadas (regiões da nasofaringe e traqueobronquial) e podem ser transferidas para o esôfago por transporte mucociliar e serem deglutidas. Já os compostos alquila de chumbo podem estar presentes no ar na forma de vapor. $\mathrm{O} \mathrm{Pb}$ tetralquila inalado é quase que totalmente absorvido após a deposição no trato respiratório (U.S.EPA, 2006).

A absorção do $\mathrm{Pb}$ inorgânico pelo trato gastrintestinal (GI) é influenciada pelo estado fisiológico do indivíduo exposto (idade, jejum, condição nutricional em relação a ferro e cálcio, gravidez), pelas características físico-químicas do material ingerido ao qual o chumbo está aderido (tamanho da partícula, mineralogia, solubilidade, espécie do chumbo) e pela quantidade de chumbo ingerida (U.S.EPA, 2006). Alguns estudos demonstram que durante a gravidez a absorção de chumbo aumenta e, juntamente com fatores como mobilização do metal nos ossos, leva ao aumento dos níveis sanguíneos na segunda metade do período de gravidez (Rothenberg et al., 1994; Lagerkvist et al., 1996; Gulson et al., 1997, 2004).

A absorção GI do chumbo hidrossolúvel em crianças é maior do que em adultos. Em crianças, a absorção é de $40 \%$ a $50 \%$ do chumbo ingerido, 
enquanto que em adultos essa taxa varia de $3 \%$ a $10 \%$. Porém em jejum, a absorção em adultos pode ser próxima de $50 \%$, este aumento pode ser devido à presença de certos minerais na dieta, como cálcio e fosfato que diminuem a absorção do chumbo (U.S.EPA, 2006; Gulson et al., 2001).

Crianças com deficiência de ferro apresentam concentrações mais altas de chumbo no sangue. Sugerindo que a deficiência de ferro leva ao aumento da absorção ou a mudanças na toxicocinética do metal, que elevam as concentrações de chumbo no sangue. Estudos com animais mostraram que dietas pobres em ferro por períodos prolongados, aumentam a absorção e retenção desse metal (Mahaffey, 1998).

A via de menor importância para absorção de compostos inorgânicos de chumbo é a dérmica. Poucos estudos fornecem estimativas quantitativas da absorção por essa via em seres humanos. Também não se sabe ao certo qual a sua contribuição para o conteúdo corpóreo de chumbo. Já os compostos de $\mathrm{Pb}$ tetralquila são, em relação aos compostos inorgânicos e sais orgânicos de chumbo, rapidamente e extensamente absorvidos pela pele, como demonstram estudos com coelhos e ratos (U.S.EPA, 2006).

Como o chumbo é qualitativamente um análogo biológico do cálcio, sua entrada e liberação do esqueleto são, em parte, controladas por muitos dos mecanismos que regulam a homeostase do mineral (Moreira e Moreira, 2004). Assim, condições como gravidez, lactação, menopausa e osteoporose aumentam a mobilização do chumbo nos ossos e conseqüentemente elevam sua concentração no sangue. O chumbo pode ser transferido da mãe para o feto e também para o leite materno (ATSDR, 2007; Gulson et al., 2003). 
As concentrações de chumbo no sangue variam com a idade e são influenciadas por inúmeros fatores que afetam a exposição. Ele é encontrado principalmente nas células vermelhas (99\%), onde a maior parte está ligada a proteínas. A ácido delta aminolevulínico desidratase é o principal ligante do chumbo nos eritrócitos (U.S.EPA, 2006). Estima-se que o plasma contenha entre $0,2 \%$ a $10 \%$ do metal no sangue, provavelmente ligada à albumina, $\alpha_{2}$-globulina ou como íons livres disponíveis para o transporte aos tecidos. É possível que esta última fração tenha maior importância toxicológica do que aquela nos eritrócitos, por estar mais biodisponível para atingir os sítios-alvos da ação toxicológica. Mas as concentrações plasmáticas de chumbo raramente são medidas devido às dificuldades analíticas e, por isso, sua relação com as manifestações tóxicas não está claramente definida (Moreira e Moreira, 2004).

Em adultos, $94 \%$ do chumbo presente no organismo encontra-se nos ossos, em crianças essa porcentagem é de 73\% (Barry, 1975). No estudo realizado por Barry (1975) em tecidos provenientes de necropsia, evidenciou-se também maior acúmulo em ossos de adultos do sexo masculino comparativamente a mulheres adultas. Mas essa diferença entre sexos não foi percebida em crianças. O conteúdo de $\mathrm{Pb}$ nos ossos aumenta com a idade e essa reserva pode ser responsável por manter os níveis sangüíneos de chumbo por muito tempo após cessar a exposição externa (Fleming et al., 1997).

Independentemente da via de exposição, o chumbo absorvido é excretado principalmente na urina e fezes, outras vias de excreção menos 
importante são suor, saliva, cabelo, unha e leite materno (U.S.EPA, 2006). A quantidade eliminada por qualquer via depende da idade e das características da exposição, além da espécie de chumbo (Paoliello e De Capitani, 2003). Aparentemente as crianças parecem ter uma taxa total de excreção de chumbo menor do que os adultos. Crianças até dois anos de idade retêm $34 \%$ da quantidade total de chumbo absorvido, enquanto que os adultos retêm apenas 1\% (Moreira e Moreira, 2004).

\section{Efeitos à saúde decorrentes da exposição ambiental ao chumbo}

Os efeitos mais preocupantes de exposições ambientais ao chumbo são os cardiovasculares e renais, hematológicos e os efeitos neurológicos em crianças (ATSDR, 2007).

Apesar de o chumbo apresentar vários efeitos no sistema cardiovascular em animais, os efeitos mais preocupantes da exposição humana a níveis baixos, são a elevação da pressão sangüínea e a diminuição na taxa de filtração glomerular. Esses efeitos podem estar relacionados e, também, ser confundidores e covariáveis em estudos epidemiológicos. A diminuição da taxa de filtração glomerular pode contribuir para a elevação da pressão, e o aumento desta pode predispor à doença glomerular (ATSDR, 2007).

Estudos epidemiológicos sugerem que o chumbo pode elevar a pressão sanguínea em adultos mesmo em concentrações no sangue menores que $200 \mu \mathrm{g} / \mathrm{L}$ (Kosnett et al., 2007). Em 3 meta análises de estudos que investigaram a relação entre $\mathrm{Pb}$ em sangue e pressão sanguínea foram 
encontradas essa relação. Os estudos mostraram coeficientes estatisticamente significantes entre aumento de duas vezes das concentrações do metal em sangue e incremento de $1,0 \mathrm{mmHg}$ ou 1,25 mmHg para a pressão sistólica, e $0,6 \mathrm{mmHg}$ para a pressão diastólica (Kosnett et al., 2007).

A influência da exposição ao chumbo na pressão sanguínea em humanos é biologicamente plausível. O chumbo induz hipertensão em ratos, e outros estudos com animais sugerem que o chumbo atua em múltiplos sítios no sistema cardiovascular, incluindo efeitos diretos na excitabilidade e contratividade do coração, na conformidade do músculo liso vascular, e ação direta nas partes do sistema nervoso central responsável pela regulação da pressão sanguínea (Nash et al., 2003; U.S.EPA, 2006; Navas-Acien et al., 2007).

O chumbo é um metal neurotóxico bem conhecido. A diminuição da capacidade de desenvolvimento neurológico em crianças é o principal efeito crítico do chumbo. Exposições no útero, pelo leite materno ou na primeira infância, podem ser responsáveis por esses efeitos, portanto, o tempo de exposição da mulher antes de engravidar é importante. Estudos epidemiológicos mostram efeitos cognitivos em crianças associados com níveis de chumbo no sangue entre 100 a $150 \mu \mathrm{g} / \mathrm{L}$ na mulher grávida, no sangue do cordão umbilical ou da criança. Há indicações de efeitos deletérios do chumbo em concentrações no sangue mesmo abaixo de 100 $\mu g / L$, e não há um limite seguro estabelecido abaixo do qual não ocorra efeito (WHO, 2007, Rothenberg, 2008). 


\subsubsection{Toxicologia do Cádmio}

\section{Identificação, ocorrência e usos}

O cádmio é um elemento que ocorre naturalmente na crosta terrestre na forma de minério, principalmente combinado com outros compostos como oxigênio, cloro ou enxofre e como minério de chumbo, zinco e cobre. O cádmio puro é um metal maleável, branco prateado e raramente é encontrado na natureza. As diferentes formas de compostos de cádmio são sólidos solúveis em água, sendo cloretos e sulfetos os mais solúveis. Os compostos de cádmio podem ser transformados, mas o metal cádmio não desaparece do ambiente. É um poluente persistente, acumula-se na cadeia alimentar (ATSDR, 1999b).

Pequenas quantidades de cádmio são liberadas no ambiente em decorrência do desgaste de rochas, de incêndios florestais e de emissões vulcânicas, mas a maioria é proveniente das atividades humanas (ATSDR, 1999b). Essas podem ser divididas em duas categorias: a primeira é relativa às atividades envolvendo mineração, produção, consumo e disposição de produtos que utilizam cádmio (baterias de Ni-Cd, pigmentos, estabilizadores de produtos de policloreto de vinila (PVC), recobrimento de produtos ferrosos e não ferrosos, ligas de cádmio e componentes eletrônicos). A segunda categoria são as fontes "inadvertidas" onde o cádmio é um constituinte natural do material que está sendo processado ou consumido como metais não-ferrosos, ligas de zinco, chumbo e cobre, emissões de indústrias de ferro e aço, combustíveis fósseis (carvão, óleo, gás , turfa e 
madeira), cimento e fertilizantes fosfatados (ATSDR, 1997; Chasin e Cardoso, 2003; WHO, 1992). O lixo urbano contém Cd, podendo contaminar o composto orgânico, produto da reciclagem e o chorume, líquido gerado no lixo e que é lançado em corpos receptores (rios) ou penetra no solo podendo alcançar as águas subterrâneas (Chasin e Cardoso, 2003).

O cádmio foi incluído na lista de substâncias e processos considerados potencialmente perigosos ao planeta pelo IRPTC (International Register of Potentially Toxic Chemical) do Programa das Nações Unidas para o Meio Ambiente (WHO, 1992). Os padrões de segurança estabelecidos pelas agências competentes, mostram a preocupação em se estabelecer o risco associado à exposição ao cádmio. Há, nos Estados Unidos, cerca de 800 regulamentações, recomendações e diretrizes aplicáveis ao cádmio e a seus compostos, em níveis federal e estadual que dispõem sobre critérios acerca da utilização e descarte. O objetivo é minimizar os riscos relativos à exposição humana e ao meio ambiente (ATSDR, 1997).

\section{Toxicocinética}

O cádmio é absorvido tanto por inalação como pela via digestiva. A absorção pulmonar do cádmio inalado varia de 10\% a 50\% (WHO, 1992; WHO 2007). Em exposição não ocupacional, a concentração de cádmio no fígado aumenta continuamente com a idade. Em exposições ambientais a níveis baixos, aproximadamente 30 - 50\% da carga corporal do metal é armazenado nos rins (WHO, 2007). 
Para não fumantes, o alimento é a principal fonte de exposição ambiental de cádmio. Os níveis mais altos do metal são encontrados em rins e fígado de mamíferos e em certas espécies de mexilhões e ostras. A absorção do cádmio pelo trato digestivo é de aproximadamente 3-5\%, mas pode ser maior em indivíduos com deficiência de ferro. Fatores como dieta com alto conteúdo de gordura ou proteína, ou deficiência de zinco também podem influenciar a absorção do cádmio pela via digestiva (WHO, 2000b).

A absorção do cádmio pela pele é em geral muito baixa $(0,2-0,8 \%)$. A distribuição do cádmio é relativamente independente da via de exposição, ele é distribuído pelo corpo atingindo níveis mais altos no fígado e rins. O cádmio não sofre nenhuma conversão metabólica direta, porém o íon Cd pode se ligar a grupos aniônicos como o sulfidrila em proteínas, em especial albumina e metalotioneína. A metalotioneína é uma proteína de peso molecular pequeno rica em cisteína, que é capaz de se ligar a esse metal em vários tecidos. Dessa maneira, grandes quantidades de $\mathrm{Cd}$ podem ficar retidas no corpo, e, sob essa forma, o Cd é relativamente não tóxico (ATSDR, 1999b).

O Cd absorvido é eliminado do organismo principalmente pela urina. No entanto, a quantidade de Cd excretada diariamente por essa via é muito pequena, representa somente cerca de $0,005-0,01 \%$ do total da carga corporal, que corresponde a uma meia-vida biológica de 20-40 anos. O conteúdo do metal na urina é um indicador confiável do conteúdo corpóreo (WHO, 2000b).

O Cd tem uma meia-vida biológica excepcionalmente longa, resultando em acúmulo no organismo. No sangue, mais de $90 \%$ do metal é 
encontrado nas células. A concentração de cádmio no sangue representa os dois principais aspectos da exposição ao cádmio. O primeiro reflete a exposição recente, com meia vida de 2 a 3 meses, o outro está relacionado com a carga corporal, isto é, mesmo cessada a exposição, o metal pode ser mobilizado dos locais de armazenamento e ser liberado para a corrente sangüínea, com meia vida aproximada de uma década. Para população com exposição ambiental contínua e relativamente baixa ao cádmio, a concentração de cádmio no sangue é um bom marcador para exposição crônica (WHO, 2000b).

\section{Efeitos à saúde decorrentes da exposição ambiental ao cádmio}

Nas situações de exposição crônica, a toxicidade se expressa nos rins em nível de túbulo proximal provocando dano celular com proteinúria (principalmente proteínas de baixo peso molecular como, por exemplo, a $\beta_{2}$-microglobulina), glicosúria, aminoacidúria, poliúria, decréscimo da absorção de fosfato e enzimas, em humanos e em vários animais de experimentação. Há demonstrações de haver aumento da peroxidação lipídica (ATSDR, 1999b; WHO, 1992).

Na Bélgica, a avaliação da população exposta ao cádmio do ambiente, realizada no período de 1985 a 1989 (CadmiBel Study), mostrou uma associação entre a exposição ao cádmio e o aumento da prevalência de resultados anormais em testes de função renal (acima do percentil 95 do grupo controle). Em particular, a excreção urinária de cálcio, de $\beta 2-\mathrm{M}$, proteína ligada ao retinol, e de $\mathrm{N}$-acetil- $\beta$-d-glicosaminidase tiveram 
associação significativa com a carga corporal de cádmio, estimada pela determinação urinária do metal (Buchet et al., 1990).

Um outro estudo realizado na Suécia com mulheres de 53 a 64 anos, verificou a relação entre a exposição ao cádmio e a função glomerular e tubular. Concentrações de cádmio no sangue de $0.38 \mu \mathrm{g} / \mathrm{L}$ (média) e na urina de $0.52 \mu \mathrm{g} / \mathrm{L}(0.67 \mu \mathrm{g} / \mathrm{g}$ creatinina) foram associados a efeitos nos túbulos renais, indicado pelo aumento da concentração do complexo proteína e $\mathrm{N}$-acetil- $\beta$-d-glucosaminidase na urina. A associação foi mais significativa a concentrações baixas de exposição, em mulheres que nunca fumaram. Relação entre marcadores da taxa de filtração glomerular e clearance de creatinina também foi encontrada em concentração de cádmio na urina de $0.6 \mu \mathrm{g} / \mathrm{L}(0.8 \mu \mathrm{g} /$ gcreatinina) $(\mathrm{WHO}, 2007)$.

\subsubsection{Toxicologia do Mercúrio}

\section{Identificação, ocorrência e usos}

O mercúrio ocorre naturalmente no ambiente e existe sob várias formas, $\mathrm{Hg}$ elementar (mercúrio metálico), espécies de $\mathrm{Hg}$ inorgânico e espécies de mercúrio orgânico (ATSDR, 1999c; Azevedo, 2003). O mercúrio metálico é um metal brilhante, branco prateado e líquido a temperatura ambiente. Os compostos de mercúrio inorgânico ou sais de mercúrio são formados quando o mercúrio se combina com elementos como cloro, enxofre e oxigênio. A maioria dos sais do metal são pós brancos ou cristais, exceto o sulfeto de mercúrio (também conhecido como cinábrio) que é 
vermelho e torna-se preto após exposição à luz. A maioria das formas de metilmercúrio e fenilmercúrio são sólidas cristalinas brancas. No ambiente, o Hg pode ser transformado de uma forma para outra pela ação de alguns microrganismos (bactérias e fungos). O composto mais comum de mercúrio formado pela ação de microrganismos ou processos naturais é o metilmercúrio. Ele é de particular importância devido a sua capacidade de se bioacumular em peixes e mamíferos marinhos, a níveis muito superiores do que os presentes na água (ATSDR, 1999c).

As emissões naturais de mercúrio são resultado da atividade vulcânica, desgaste de rochas e da crosta terrestre, e liberação a partir dos oceanos. Fontes antropogênicas incluem a queima de combustíveis fósseis, mineração, incineração de lixo urbano e até 1970, os compostos de mercúrio eram usados como pesticidas (ATSDR, 1999c). Outras fontes incluem cosméticos como cremes para clareamento da pele, timerosal em vacinas, termômetros e outras prescrições médicas (WHO, 2007).

As espécies mais tóxicas do metal são o metilmercúrio e o dimetilmercúrio. A exposição humana ao metilmercúrio ocorre principalmente pela dieta, mais especificamente pelo consumo de peixe. As amálgamas dentárias constituem a principal fonte de exposição ao mercúrio elementar na população geral. A emissão dos vapores de Hg emitidos pela amálgama, pode culminar em concentrações de $\mathrm{Hg}$ no ar intra oral superiores às do ambiente externo (WHO, 2007).

As concentrações de Hg na água de beber em geral são muito baixas, menores que $1 \mathrm{ng} / \mathrm{L}$. No solo, as concentrações mais altas são de áreas urbanas e próximas a fontes de emissão (WHO, 2007). 


\section{Toxicocinética}

A toxicocinética do mercúrio depende da sua espécie química, pois os processos de transporte são influenciados pelo estado de oxidação e pela forma de mercúrio. Na forma metálica, o mercúrio elementar $\left(\mathrm{Hg}^{0}\right)$ não é muito absorvido pelo sistema digestivo humano, é quase que completamente excretado pelas fezes, causando pouco efeito tóxico. Já pela via inalatória, o vapor de mercúrio metálico é rapidamente absorvido, sendo que cerca de $80 \%$ do mercúrio inalado é absorvido pelos pulmões e é rapidamente distribuído pelo organismo, atravessa as barreiras hemato-encefálica e placentária, chegando ao cérebro e aos rins (ATSDR, 1999c).

Na forma inorgânica do $\mathrm{Hg}$, por exemplo sais inorgânicos como aerossol de $\mathrm{HgCl}_{2}$, a absorção pulmonar vai depender do tamanho da partícula do aerossol do sal inalado. Cerca de 7 a $8 \%$ dos compostos inorgânicos presentes nos alimentos são absorvidos no trato $\mathrm{Gl}$, enquanto que os presentes na água de beber são em até 15\%. Sais de mercúrio inorgânico podem ter alguma absorção através da pele, principalmente pelos orifícios dos folículos pilosos e pelas glândulas sebáceas. Alguns desses sais são corrosivos (Azevedo, 2003).

Devido ao transporte do mercúrio por todo ambiente e sua bioacumulação, a principal fonte de exposição na população geral é pela alimentação, em particular pelo consumo de peixe (WHO, 2007). O metilmercúrio ( $\mathrm{MeHg}$ ) é facilmente absorvido pelo trato $\mathrm{Gl}$, passando para a corrente sanguínea onde é rapidamente transportado para outras partes do corpo. Cerca de $95 \%$ do $\mathrm{MeHg}$ ingerido pelo consumo de peixe 
é absorvido (Clarkson, 2002). Porém, estudos mais recentes indicam que há uma variabilidade na absorção do metilmercúrio por essa fonte (Mergler et al., 2007).

Estudos epidemiológicos ambientais mostram que diferenças étnicas influem na relação entre ingresso de $\mathrm{Hg}$ através do consumo de pescado e os biomarcadores de exposição, sugerindo que as diferenças na dieta e/ou metabólicas influenciam na absorção e/ou excreção de $\mathrm{Hg}$ (Mergler et al., 2007). Canuel et al. (2006) estudaram 3 comunidades no Canadá para verificar a relação entre ingresso de $\mathrm{Hg}$ pelo consumo de pescado e concentrações do metal em cabelo. Em uma das comunidades, a média das concentrações de $\mathrm{Hg}$ no cabelo foi 14 vezes menor do que a esperada, que foi calculada com base na exposição por via oral diária e no conhecimento atual do metabolismo do $\mathrm{MeHg}$. Os autores atribuem esse resultado às diferenças nas características genéticas específicas e/ou dos efeitos interativos de outros componentes da dieta.

O MeHg é transferido da placenta para o feto. Apesar das concentrações de $\mathrm{Hg}$ no sangue do cordão umbilical e materno apresentarem correlação, o MeHg no sangue do cordão é mais alto do que do correspondente materno, na razão de 1,7 (Mergler et al., 2007).

O MeHg pode ser metabolizado a mercúrio inorgânico, que se acumula principalmente nos rins, essa transformação pode ocorrer também no cérebro. O MeHg é excretado lentamente nas fezes. Cerca de 45 a 60 dias são necessários para que as concentrações no sangue caiam pela metade. Ele também se acumula nos cabelos (WHO, 2007). 
As concentrações de $\mathrm{Hg}$ em sangue e cabelo são aceitos como biomarcadores validados de exposição ao $\mathrm{MeHg}$. O sangue fornece uma estimativa da exposição recente, com meia vida de $\mathrm{MeHg}$ no sangue de 50-70 dias, enquanto que o cabelo reflete a média de exposição durante o período de crescimento do segmento. Porém, há de se considerar que a estimativa usada de crescimento do cabelo com sendo de $1 \mathrm{~cm} / \mathrm{mês}$ é variável tanto inter como intraindivíduo (Mergler et al., 2007).

\section{Efeitos à saúde decorrentes da exposição ambiental ao mercúrio}

Os efeitos à saúde decorrentes de exposição a níveis baixos a moderados de $\mathrm{MeHg}$, dependem de diferentes aspectos da exposição, p.ex. padrão de consumo de pescado, tempo de exposição (durante gestação, infância, fase adulta) (Mergler et al., 2007).

Mesmo sendo a exposição ambiental ao MeHg em níveis mais baixos do que aqueles que produziram as históricas epidemias de intoxicação por MeHg, cada vez mais há evidências de que para muitas populações as exposições em níveis suficientes para alterar o funcionamento normal de alguns sistemas, já constituem um importante problema de saúde pública. A níveis subclínicos e populacional, vários estudos em diferentes parte do mundo reportam alguma alteração no estado neurológico e desenvolvimento mais lento em recém-nascidos e crianças, expostas ao MeHg durante a gestação ou na primeira infância (Mergler et al., 2007).

O mecanismo de toxicidade do mercúrio é devido, na maioria dos casos, à sua alta afinidade com grupos sulfidrila e tiólicos de proteínas, 
enzimas e de substâncias de baixo peso molecular (como a coenzima A, cisteína, glutation, lipoato e tioglicolato). O mercúrio também pode se ligar a outros grupos químicos (amida, amina, carboxila fosfato), ligações menos favoráveis do que com os grupos sulfidrila, mas que causam alterações da atividade enzimática e da estrutura de proteínas e de membranas das células (Azevedo, 2003). Uma variedade de alterações induzidas pelo mercúrio tem sido investigada, incluindo aumento do stress oxidativo, interrupção da formação de microtúbulo, aumento da permeabilidade da barreira hematoencefálica, interrupção da síntese de proteínas, interrupção da replicação de DNA e atividade da DNA polimerase, dano à transmissão sináptica, ruptura da membrana, dano à resposta imune e interrupção da homeostase do cálcio. Essas alterações podem ocorrer sozinhas ou em combinação. O mercúrio também pode afetar a atividade da enzima microssomal hepática (ATSDR, 1999c).

Estudos em populações expostas a metilmercúrio pelo consumo de peixe sugerem uma associação com o aumento de incidência de doenças cardiovasculares (WHO, 2007). Sørensen et al. (1999) verificaram a associação entre a exposição pré natal ao metilmercúrio e a função cardíaca em crianças de 7 anos de idade. Com o aumento da concentração de mercúrio no cordão umbilical de $1 \mu \mathrm{g} / \mathrm{L}$ para $10 \mu \mathrm{g} / \mathrm{L}$, houve aumento da pressão sangüínea diastólica e sistólica para 13,9 mmHg e 14,6 mmHg, respectivamente. Em meninos, a freqüência cardíaca diminuiu cerca de $47 \%$ com aumento da concentração de mercúrio no cordão umbilical de $1 \mu \mathrm{g} / \mathrm{L}$ para $10 \mu \mathrm{g} / \mathrm{L}(\mathrm{WHO}, 2007)$. 


\section{OBJETIVOS}

Geral

Propor valores de referência para chumbo, cádmio e mercúrio total no sangue de adultos, sem exposição ocupacional a esses metais, residentes na Região Metropolitana de São Paulo (RMSP).

\section{Específicos}

- Obter dados das concentrações de $\mathrm{Pb}, \mathrm{Cd}$ e $\mathrm{Hg}$ em sangue de uma amostra da população;

- Derivar valores de referência desses metais para população adulta da Região Metropolitana de São Paulo; e

- Verificar associação entre os valores das concentrações dos metais estudados e variáveis sócio-demográficas e de estilo de vida. 


\section{MÉTODOS}

\subsection{Período e desenho do estudo}

O estudo foi de corte transversal, com a determinação das concentrações de chumbo, cádmio e mercúrio total no sangue de uma amostra de doadores da Colsan - Associação Beneficente de Coleta de Sangue, administrada pela UNIFESP - Universidade Federal de São Paulo. As amostras foram coletadas no período de 15 de novembro a 16 de dezembro de 2006.

\subsection{Estudo piloto e cálculo do tamanho da amostra}

Com o objetivo de testar o método de quantificação de chumbo e cádmio em sangue, realizar o pré-teste do questionário e obter subsídios para calcular o tamanho da amostra, foi realizado estudo piloto com funcionários da Cetesb nos períodos de junho a setembro de 2004 e 2005. Os participantes do estudo eram funcionários que estavam sendo submetidos ao exame ocupacional anual obrigatório. O exame periódico inclui análise de sangue, urina e fezes, assim por questões logísticas 
escolheu-se esse grupo. No momento da coleta de material biológico, realizado no ambulatório de saúde ocupacional da Cetesb, os funcionários eram abordados e após exposição do objetivo do projeto, aqueles que se dispusessem a participar voluntariamente eram entrevistados e uma alíquota a mais de sangue era coletada desses indivíduos, e essa amostra era encaminhada ao Laboratório de Análises Toxicológicas da Cetesb para serem analisadas.

Participaram do estudo 239 empregados, de ambos os sexos, com idades variando de 19 a 77 anos, que não tinham exposição ocupacional ao chumbo e cádmio, e que residiam na Região Metropolitana de São Paulo. O método de determinação desses metais em sangue foi o espectrométrico de absorção atômica em forno de grafite utilizando um equipamento Perkin Elmer modelo SIMAA 6000, com amostrador automático AS-72. O método analítico permitiu a determinação simultânea de chumbo e cádmio.

O método de análise de metais utilizado nesse estudo piloto, baseado em Correia e Oliveira (2003), mostrou-se inadequado para a determinação de quantidades traços de cádmio, pois o limite de quantificação do método ${ }^{1}$ (LQ) para esse metal foi muito elevado, 1,0 $\mathrm{\mu g} / \mathrm{L}$, ficando $93 \%$ dos resultados abaixo desse limite. Assim, o estudo piloto apontou a necessidade de se desenvolver um método analítico mais sensível, isto é,

\footnotetext{
${ }^{1}$ Limite de Quantificação é a menor concentração de um analito em uma amostra que pode ser determinada quantitativamente com precisão e exatidão aceitáveis, nas condições de rotina do laboratório. É também definido por convenção, ser a concentração do analito correspondente ao valor do branco mais 5,6 ou 10 desvios-padrão da média do branco. $\mathrm{Na}$ prática, corresponde normalmente ao padrão de calibração de menor concentração (excluindo o branco) (Eurachem, 1998; INMETRO, 2007).
} 
com LQ mais baixo, pois a população a ser estudada seria de indivíduos expostos a níveis ambientais aos metais em questão, apresentando, portanto, concentrações baixas desses contaminantes no sangue. Um novo método, o de Kummrow et al. (2008) (Anexol), desenvolvido pela equipe da Cetesb em conjunto com o Instituto de Química da USP, possibilitou atingir um LQ para o cádmio dez vezes menor do que o usado no estudo piloto.

A aplicação do questionário no estudo piloto identificou problemas estruturais do mesmo que dificultava o seu preenchimento e a obtenção das informações pretendidas. O questionário foi então reformulado para ser utilizado no projeto. As principais mudanças foram em relação à renda, classificação da área residencial, dieta e consumo de bebida alcoólica, como pode ser observado no Quadro 1.

Quadro 1 - Principais alterações realizadas no questionário do estudo piloto para ser usado no estudo com doadores

\begin{tabular}{|c|c|c|}
\hline Estudo piloto & Estudo com doadores & Justificativa \\
\hline $\begin{array}{l}\text { Renda familiar, por } \\
\text { número de salários } \\
\text { mínimos }\end{array}$ & $\begin{array}{l}\text { Renda per capita, por } \\
\text { faixa de salário em } \\
\text { reais }\end{array}$ & $\begin{array}{l}\text { A renda per capita é mais } \\
\text { informativa da condição } \\
\text { sócio-econômica do } \\
\text { indivíduo e percebeu-se que } \\
\text { para o entrevistado era mais } \\
\text { fácil responder se as faixas } \\
\text { estivessem em reais }\end{array}$ \\
\hline $\begin{array}{l}\text { Área residencial: urbana } \\
\text { (centro), urbana (bairro) } \\
\text { e rural }\end{array}$ & $\begin{array}{l}\text { Esta informação foi } \\
\text { retirada }\end{array}$ & $\begin{array}{l}\text { As pessoas tinham } \\
\text { dificuldade para classificar a } \\
\text { área }\end{array}$ \\
\hline $\begin{array}{l}\text { Tipo de dieta, carnívora, } \\
\text { vegetariana, mista e } \\
\text { macrobiótica }\end{array}$ & Foi retirada & $\begin{array}{l}\text { A grande maioria tem dieta } \\
\text { mista }\end{array}$ \\
\hline $\begin{array}{l}\text { Consumo de bebida } \\
\text { alcoólica por tipo e } \\
\text { quantidade em copos/dia }\end{array}$ & $\begin{array}{l}\text { Substituída por } \\
\text { freqüência de consumo }\end{array}$ & $\begin{array}{l}\text { Dificuldade de o } \\
\text { entrevistado relatar as } \\
\text { quantidades }\end{array}$ \\
\hline
\end{tabular}


Devido aos problemas analíticos já descritos no item anterior, os resultados das concentrações de cádmio no estudo piloto, ficaram na sua maioria abaixo do LQ, o que inviabilizou a sua utilização para o cálculo do tamanho da amostra. Por essa razão, apenas as concentrações de chumbo em sangue obtidas no estudo piloto foram utilizadas para o cálculo do tamanho da amostra. A partir das médias e variação encontradas, estimouse o tamanho da amostra para o estudo com os doadores de sangue. As concentrações médias de chumbo encontradas no estudo piloto foram $21,8 \pm 8,1 \mu \mathrm{g} / \mathrm{L}$ para faixa etária compreendida entre 18 e 40 anos e 29,1 \pm $13,3 \mu \mathrm{g} / \mathrm{L}$ para a faixa de 41 a 65 anos. No estudo piloto, sexo e faixa etária foram as variáveis mais associadas aos níveis de chumbo em sangue.

A Tabela 1, mostra o número amostral necessário estimado por níveis de precisão e as médias de plumbemia com os respectivos desvios-padrão.

Tabela 1 - Níveis de precisão, média de plumbemia (DP) e número amostral estimado por faixa etária

\begin{tabular}{lccccc}
\hline Precisão & Faixa etária (anos) & Média $(\mu g / L)$ & $D P$ & $\boldsymbol{N}$ & Amostra total \\
\hline \multirow{2}{*}{$5 \%$} & 18 a 40 & 21,8 & 8,1 & 212 & \\
& 41 a 65 & 29,1 & 13,3 & 321 & 533 \\
\multirow{2}{*}{$\mathbf{6 \%}$} & 18 a 40 & 21,8 & 8,1 & 147 & \\
& 41 a 65 & 29,1 & 13,3 & 223 & 360 \\
\multirow{2}{*}{$7 \%$} & 18 a 40 & 21,8 & 8,1 & 108 & \\
& 41 a 65 & 29,1 & 13,3 & 164 & 272 \\
\hline
\end{tabular}


Optou-se por $5 \%$ de precisão, com tamanho da amostra de 533. No entanto, para que o número de perdas não prejudicasse essa precisão, estabeleceu-se obter pelo menos 600 amostra.

Dos 11 postos de coleta da Colsan, 10 estão localizados na Região Metropolitana de São Paulo, distribuídos conforme Figura 5, e um no município de Jundiaí, portanto fora da RMSP. Como o contingente de doadores de sangue atendidos nos diferentes postos variava muito, decidiuse distribuir as 600 amostras estimadas, proporcionalmente à quantidade de bolsas coletadas nos postos. O cálculo foi baseado nos dados registrados pela Colsan de bolsas coletadas no mês de setembro de 2006 (Tabela 2).

Tabela 2 - Bolsas coletadas no mês de setembro de 2006, por posto da Colsan e número de amostras calculadas proporcionalmente ao número de bolsas coletadas.

\begin{tabular}{lccc}
\hline Postos de Coleta & $\begin{array}{c}\text { Bolsas } \\
\text { Coletadas }\end{array}$ & $\begin{array}{c}\text { Estimativa do } \\
\mathbf{n}^{\mathbf{0}} \text { amostras }\end{array}$ & $\%$ \\
\hline Campo Limpo & 437 & 38 & $\mathbf{6 , 3}$ \\
*Santo André I e II & 2440 & 211 & $\mathbf{3 5 , 1}$ \\
Ermelino Matarazzo & 440 & 38 & $\mathbf{6 , 3}$ \\
Ipiranga & 641 & 55 & $\mathbf{9 , 2}$ \\
São Bernardo & 725 & 62 & $\mathbf{1 0 , 4}$ \\
São Caetano & 343 & 29 & $\mathbf{4 , 9}$ \\
Tatuapé & 710 & 61 & $\mathbf{1 0 , 2}$ \\
Tide Setúbal & 356 & 31 & $\mathbf{5 , 1}$ \\
Vergueiro & 859 & 75 & $\mathbf{1 2 , 4}$ \\
\hline Total & 6951 & $\mathbf{6 0 0}$ & $\mathbf{9 9 , 9}$ \\
\hline
\end{tabular}

* Por estarem localizados no mesmo município e pela proximidade, os 2 postos foram agrupados no cálculo da estimativa do $\mathrm{n}^{\circ}$ de amostras 


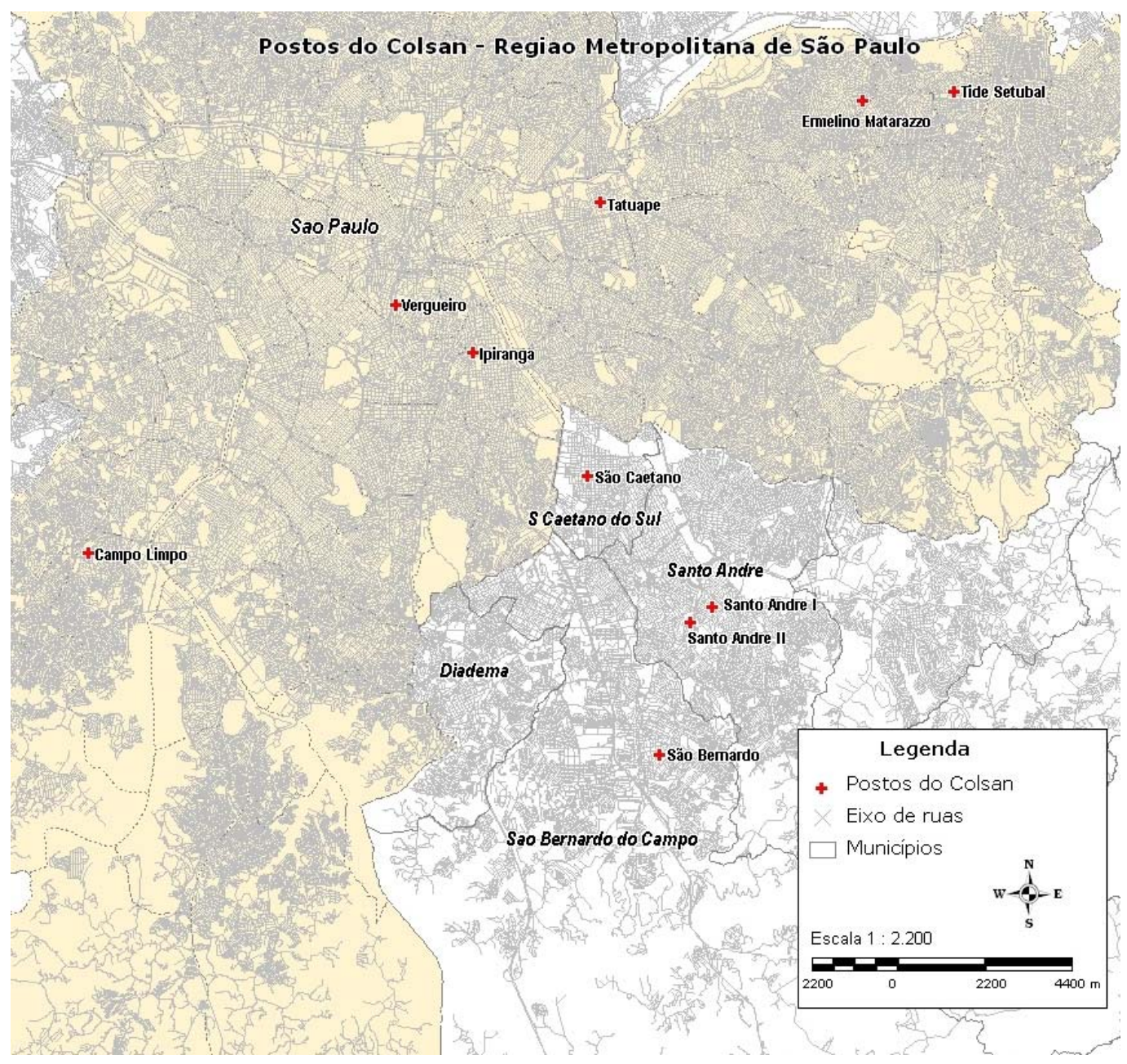

Figura 5 - Localização dos Postos da Colsan da Região Metropolitana de São Paulo

\subsection{População de estudo}

Participaram do estudo 653 doadores de sangue da Colsan. Segundo dados de 2007, essa entidade atendeu cerca de 109.490 doadores no ano nos seus 11 postos de coleta. O presente estudo incluiu 9 postos localizados na RMSP, foram excluídos o posto localizado no município de Jundiaí por não fazer parte da RMSP e o posto São Caetano devido ao afluxo muito baixo de doadores. 
Foram excluídos os indivíduos que:

a) Não residiam na Região Metropolitana de São Paulo a pelo menos um mês;

b) Fumavam; e

c) Tinham exposição ocupacional a pelo menos um dos metais chumbo, cádmio e mercúrio.

Esses critérios de exclusão tiveram por objetivo garantir que a população estudada fosse formada apenas por moradores da RMSP cuja exposição aos metais em estudo fosse devida ao local de moradia, portanto esses deveriam ter um tempo mínimo de exposição (um mês), tempo suficiente para que se atingisse um nível sangüíneo detectável dos biomarcadores. Também para se garantir que a exposição da população estudada fosse apenas de origem ambiental, foram excluídos os fumantes, pois principalmente no caso do cádmio, o cigarro é uma fonte importante de metais (Bæcklund et al., 1999; Satarug e Moore, 2004) e, por motivos óbvios aqueles que poderiam ter uma exposição ocupacional ao $\mathrm{Pb}, \mathrm{Cd}$ e $\mathrm{Hg}$

\subsection{Coleta de amostra e aplicação do questionário}

O potencial doador era abordado na chegada ao posto de coleta pelo entrevistador que explicava o objetivo da pesquisa e perguntava do interesse do doador em participar do estudo, esclarecendo que a participação era voluntária. 
Foram coletadas amostras nos seguintes postos da Colsan: Campo Limpo, Santo André I, Ermelino Matarazzo, Ipiranga, Santo André II, São Bernardo, Tatuapé, Tide Setúbal e Vergueiro (Figura 5).

Para não prejudicar a rotina de coleta de sangue nos postos, que segue etapas seqüenciais rigorosas, conforme fluxograma da Figura 6, o planejamento da obtenção das amostras foi feito de maneira a interferir o menos possível nessa rotina. As intervenções da equipe de pesquisa eram realizadas nos momentos em que o doador estava aguardando para ser atendido entre uma etapa e outra. As amostras de sangue para a pesquisa foram obtidas no momento da coleta das amostras para os exames realizados pela Colsan como tipagem sangüínea, triagem para doença Falciforme (Hemoglobina S), exames para Hepatite B e C, HIV I e II, Sífilis, Doença de Chagas e HTLV I e II. O técnico da Colsan coletava então mais dois tubos a vácuo, com capacidade de $6 \mathrm{~mL}$ cada, contendo heparina sódica como anticoagulante, que foram imediatamente após a coleta, armazenados em recipiente refrigerado, e ao final do período diário de coleta foi entregue à equipe da Cetesb. Dessa maneira, o doador era submetido a apenas uma punção, onde eram obtidas as amostras para os exames do próprio banco de sangue e para a pesquisa, e, após a obtenção de todos os tubos, eram então colocadas, no lugar desses, as bolsas para a coleta de sangue propriamente dita dos doadores. As amostras da pesquisa eram encaminhadas ao laboratório da Cetesb, onde permaneciam armazenadas em freezer até o momento da análise de chumbo e cádmio realizada na própria Cetesb, e o segundo tubo, até ser enviado para a Agência Ambiental 
Federal da Alemanha, para determinação de mercúrio total. No período de aproximadamente uma semana após a coleta, a Colsan enviava os resultados dos testes sorológicos para a Cetesb, e, somente as amostras que apresentassem resultado negativo eram enviadas à Alemanha.

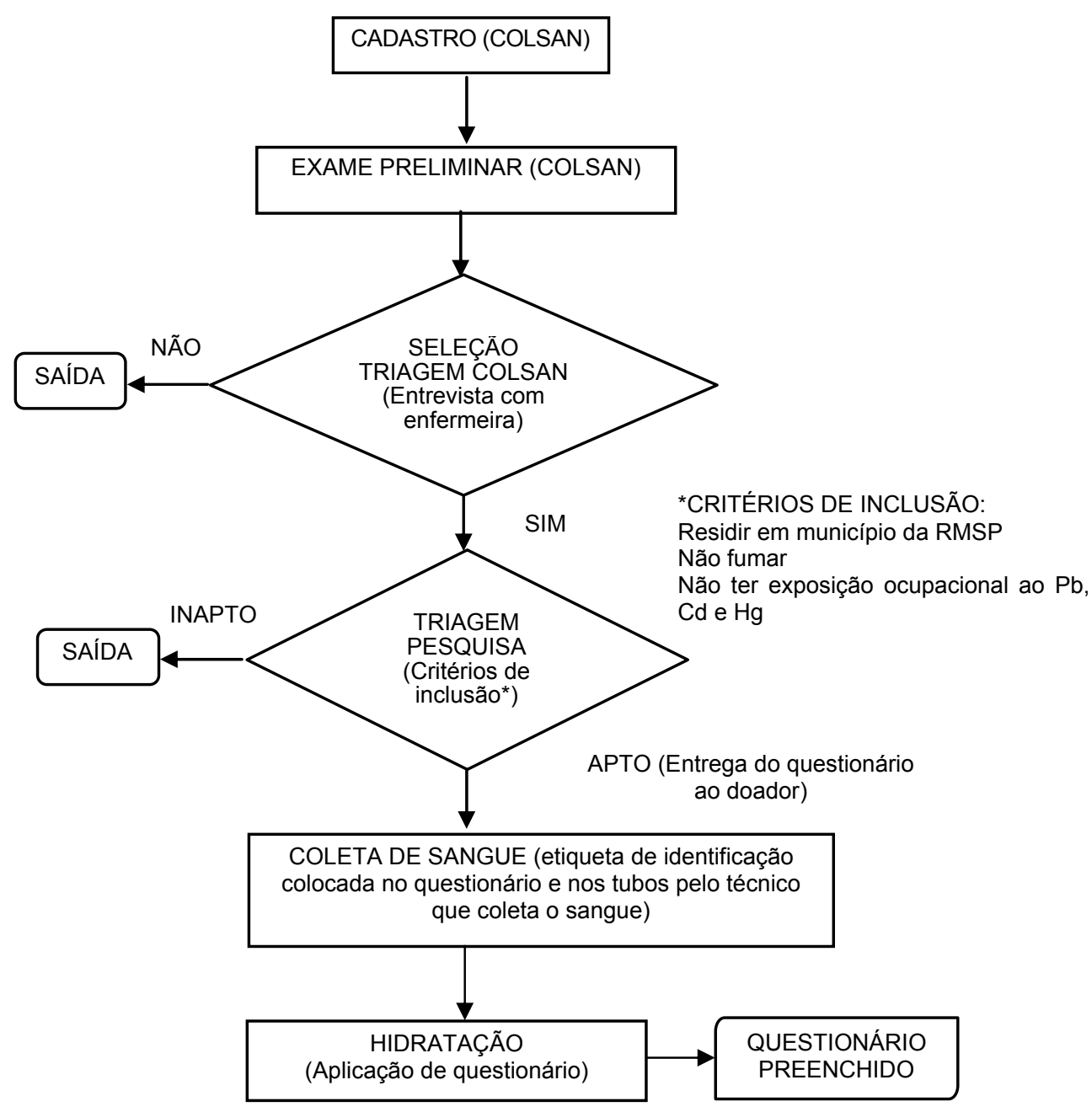

Figura 6 - Dinâmica da coleta de sangue nos postos da Colsan e as intervenções da pesquisa para seleção de doadores. 
Para controlar as variáveis independentes e possíveis variáveis de confusão, foi aplicado um questionário (Anexo II) ao doador no momento da coleta de sangue. Os doadores respondiam, por meio de entrevistas, ao questionário elaborado baseado em dados de literatura, contendo as seguintes informações: escolaridade, lazer, renda, consumo de pescado e bebida alcoólica, procedência da água de consumo, possíveis exposições ambientais, hábitos pessoais como tipo de alimentação, origem da água de beber, entre outras para identificar fatores suspeitos de ter relação com os níveis de chumbo, cádmio e mercúrio em sangue, e que auxiliaram na análise e interpretação dos resultados. Os motivos que levaram à inclusão das informações estão descritos no Quadro 2. Somente os dados pessoais não eram preenchidos no momento da entrevista, estes foram obtidos no cadastro da Colsan. A entrevista era realizada na sala de hidratação, enquanto o doador lanchava após a coleta de sangue. 
Quadro 2 - Descrição das informações incluídas no questionário dos doadores de sangue com as justificativas para sua inclusão.

\begin{tabular}{|c|c|c|}
\hline Variável & Motivo da inclusão & Referência \\
\hline Sexo & $\begin{array}{l}\text { Vários estudo mostram que os níveis de } \\
\text { metais em sangue diferem entre os sexos, } \\
\text { principalmente o Pb que apresenta níveis } \\
\text { maiores no sexo masculino }\end{array}$ & $\begin{array}{l}\text { Gerhardsson et al., 1996; } \\
\text { Vahter et al., 2002; } \\
\text { Wennberg et al., 2006; } \\
\text { Schroijen et al., } 2008\end{array}$ \\
\hline Faixa etária & $\begin{array}{l}\text { Estudos apontam níveis maiores de } \mathrm{Pb} \text { nas } \\
\text { faixas etárias maiores e alguns também } \\
\text { para } \mathrm{Hg}\end{array}$ & $\begin{array}{l}\text { Zielhuis et al., 1978; } \\
\text { Gerhardsson et al., 1996; } \\
\text { Weyermann e Brenner, } \\
\text { 1998; } \\
\text { Wennberg et al., } 2006\end{array}$ \\
\hline $\begin{array}{l}\text { Escolaridade e } \\
\text { renda }\end{array}$ & $\begin{array}{l}\text { Estudos com a população geral mostram } \\
\text { que crianças e muleres de famílias com } \\
\text { menor renda têm maior risco de apresentar } \\
\text { níveis elevados de chumbo em sangue }\end{array}$ & $\begin{array}{l}\text { Zielhuis et al., 1978; } \\
\text { Hense et al., 1992; } \\
\text { Nash et al., 2003; } \\
\text { Lee et al., 2005; } \\
\text { Morales et al, } 2005\end{array}$ \\
\hline $\begin{array}{l}\text { Consumo de } \\
\text { pescado }\end{array}$ & $\begin{array}{l}\text { A principal fonte de exposição a } \mathrm{Hg} \\
\text { orgânico é pescado }\end{array}$ & $\begin{array}{l}\text { Oskarsson et al., 1996; } \\
\text { Dickman e Leung, 1998; } \\
\text { Wennberg et al., } 2006\end{array}$ \\
\hline $\begin{array}{l}\text { Consumo de } \\
\text { bebida alcoólica }\end{array}$ & $\begin{array}{l}\text { Alguns tipos de bebidas podem apresentar } \\
\text { teores de } \mathrm{Pb} \text { e Cd como vinho e aumentar } \\
\text { os níveis de chumbo em sangue }\end{array}$ & $\begin{array}{l}\text { Gerhardsson et al., 1996; } \\
\text { MERCOSUL, 1996; } \\
\text { Weyermann e Brenner, } \\
\text { 1997; } \\
\text { Wennberg et al., 2006; }\end{array}$ \\
\hline $\begin{array}{l}\text { Procedência da } \\
\text { água de beber }\end{array}$ & $\begin{array}{l}\text { Casas antigas podem ter encanamento de } \\
\text { água com chumbo, o que pode levar ao } \\
\text { aumento dos níveis de chumbo na água }\end{array}$ & $\begin{array}{l}\text { Gerhardsson et al., 1996; } \\
\text { Morales et al., } 2005\end{array}$ \\
\hline $\begin{array}{l}\text { Uso de } \\
\text { medicamentos }\end{array}$ & $\begin{array}{l}\text { Alguns medicamentos à base de plantas } \\
\text { podem conter chumbo }\end{array}$ & $\begin{array}{l}\text { Gerhardsson et al., 1996; } \\
\text { Morales et al., } 2005\end{array}$ \\
\hline $\begin{array}{l}\text { Hábito de usar } \\
\text { goma de } \\
\text { mascar }\end{array}$ & $\begin{array}{l}\text { Esse hábito pode disponibilizar o Hg } \\
\text { presente nas restaurações de amálgama } \\
\text { do dente, aumentando a exposição a este } \\
\text { metal }\end{array}$ & $\begin{array}{l}\text { Sällsten et al., 1996; } \\
\text { Bellinger et al., } 2007\end{array}$ \\
\hline $\begin{array}{l}\text { Dentes com } \\
\text { restauração de } \\
\text { amálgama }\end{array}$ & $\begin{array}{l}\text { O Hg das amálgamas pode ser liberado } \\
\text { dentro da cavidade bucal e ser inalado ou } \\
\text { deglutido }\end{array}$ & $\begin{array}{l}\text { Sällsten et al., 1996; } \\
\text { Wennberg et al., 2006; } \\
\text { Wilhelm et al., } 2006 \\
\text { Bellinger et al, 2007; }\end{array}$ \\
\hline $\begin{array}{l}\text { Reformou a } \\
\text { casa } \\
\text { recentemente }\end{array}$ & $\begin{array}{l}\text { No passado foi muito utilizada tinta que } \\
\text { continha } \mathrm{Pb} \text { para pintar paredes. Com o } \\
\text { processo de reforma pode haver a } \\
\text { liberação das partículas de tintas contendo } \\
\mathrm{Pb} \text { para o ar do ambiente das residências } \\
\text { no momento da remoção da camada velha } \\
\text { da pintura }\end{array}$ & $\begin{array}{l}\text { Lee et al., 2005; } \\
\text { ATSDR, } 2007\end{array}$ \\
\hline
\end{tabular}


Conclusão Quadro 2

\begin{tabular}{|c|c|c|}
\hline Variável & Motivo da inclusão & Referência \\
\hline $\begin{array}{l}\text { Tem horta na } \\
\text { casa }\end{array}$ & $\begin{array}{l}\text { Como os metais estão aderidos ao MP } \\
\text { suspenso no ar, a ingestão de alimento } \\
\text { exposto aos MP pode ser uma fonte } \\
\text { importante de contaminação ambiental }\end{array}$ & $\begin{array}{l}\text { Paoliello et al., 2003; } \\
\text { Nawrot e Staessen, } 2006\end{array}$ \\
\hline $\begin{array}{l}\text { Tem fábrica } \\
\text { próxima à casa }\end{array}$ & $\begin{array}{l}\text { A proximidade a fontes de emissão dos } \\
\text { metais em estudo pode ser uma importante } \\
\text { fonte de exposição e assim pode explicar } \\
\text { níveis elevados dos metais em sangue de } \\
\text { indivíduos que residem próximos à fonte }\end{array}$ & $\begin{array}{l}\text { Kuno et al, 1994, 1995; } \\
\text { Paoliello et al., 2003; } \\
\text { Wilhelm et al., 2005 }\end{array}$ \\
\hline $\begin{array}{l}\text { Tempo da } \\
\text { última doaçãa e } \\
\text { total de doações }\end{array}$ & $\begin{array}{l}\text { O conteúdo corpóreo de } \mathrm{Pb} \text { e Cd pode } \\
\text { variar dependendo do estoque de ferro e } \\
\text { hemoglobina no organismo, que é } \\
\text { influenciado pelo tempo decorrido da última } \\
\text { doação e número de doações realizadas }\end{array}$ & $\begin{array}{l}\text { Satarug et al., 2004; } \\
\text { Djalali et al., } 2006\end{array}$ \\
\hline Hematócrito & $\begin{array}{l}\text { Alguns estudos encontraram associação } \\
\text { (negativa e positiva) com concentrações de } \\
\text { chumbo em sangue e hematócrito }\end{array}$ & $\begin{array}{l}\text { Weyermann e Brenner, } \\
\text { 1998; } \\
\text { Lee et al., 2005; }\end{array}$ \\
\hline $\begin{array}{l}\text { Uso de } \\
\text { hormônio }\end{array}$ & $\begin{array}{l}\text { As mulheres na pós-menopausa têm } \\
\text { desmineralização óssea que pode liberar } \\
\text { Pb acumulado nos ossos para a corrente } \\
\text { sanguínea, o uso de hormônio pode } \\
\text { influenciar os níveis de } \mathrm{Pb} \text {, pois interfere na } \\
\text { desmineralização óssea }\end{array}$ & $\begin{array}{l}\text { Webber et al., 1995; } \\
\text { Weyermann e Brenner, } \\
\text { 1998; } \\
\text { Garrido Latorre et al., } 2003\end{array}$ \\
\hline Pressão arterial & $\begin{array}{l}\text { Alguns trabalhos encontraram associação } \\
\text { entre } \mathrm{Pb} \text { em sangue e hipertensão }\end{array}$ & $\begin{array}{l}\text { Nash et al., 2003; } \\
\text { Kosnett et al, 2007; } \\
\text { Navas-Ancien et al., } 2007\end{array}$ \\
\hline
\end{tabular}

As equipes de entrevistadores eram compostas por técnicos e estagiários da Divisão de Toxicologia, Genotoxicidade e Microbiologia da Cetesb, e eram formadas por pelo menos 4 indivíduos, sendo um coordenador por equipe. $\mathrm{O}$ treinamento dos entrevistadores foi realizado por meio de reuniões, onde a pesquisadora fazia a apresentação do projeto de pesquisa, com enfoque principal nos objetivos e justificativa. Todos os itens do questionário eram explicados detalhadamente e os entrevistadores 
esclareciam as suas dúvidas. Além do questionário, os entrevistadores recebiam uma folha contendo os critérios de exclusão e para facilitar a aplicação desses critérios, uma listagem com os tipos de ocupação que poderiam levar à exposição aos metais em estudo, além da relação de municípios integrantes da RMSP, essa folha ficava em poder do entrevistador também no momento da entrevista (Anexo III). O treinamento visou esclarecer todas as questões abordadas no questionário, pois o entendimento das questões, bem como da importância das informações, interfere na qualidade do preenchimento e consequentemente na diminuição de respostas em branco ou invalidadas.

\subsection{Aspecto ético da pesquisa}

O protocolo de pesquisa foi aprovado pela Comissão de Ética para Análise de Projetos de Pesquisa - CAPPesq da Diretoria Clínica do Hospital das Clínicas e da Faculdade de Medicina da Universidade de São Paulo (Anexo IV) e pela Diretoria da Colsan.

À época do estudo, a Cetesb não tinha ainda implantado o método de determinação de mercúrio em sangue, por esse motivo a cooperação com a Agência Ambiental Federal da Alemanha (UBA) previu que as análises de mercúrio seriam realizadas pela agência alemã. Para o envio das amostras à Alemanha, o protocolo de pesquisa teve que ser aprovado pelo CONEP _ Conselho Nacional de Ética em Pesquisa do Ministério da Saúde (Anexo V). 
Por exigência do CONEP, para ser autorizada a remessa das amostras para o exterior, o pesquisador necessitava declarar que o material não era infeccioso. Por essa razão, somente foram enviadas à Alemanha as amostras cujo resultado para o teste sorológico, realizado pela Colsan para triagem das bolsas de sangue, era negativo. Também foi exigido pelo CONEP carta da UBA onde constava a participação da agência e os custos envolvidos na cooperação, além do comprometimento dos pesquisadores estrangeiros de que as amostras seriam utilizadas apenas para os fins declarados no projeto de cooperação.

A submissão do projeto para apreciação do CONEP é uma exigência da Resolução n 196 de 10 de outubro de 1996 do Conselho Nacional de Saúde, regulamentada pela Resolução n² 292 de 8 de julho de 1999. Além do atendimento a essas Resoluções, que dispõem sobre diretrizes e normas regulamentadoras de pesquisa envolvendo seres humanos, com item específico para "pesquisas coordenadas do exterior ou com participação estrangeira e pesquisas que envolvam remessa de material biológico para o exterior", foi necessário registro junto à ANVISA (Agência Nacional de Vigilância Sanitária) para viabilizar a remessa das amostras.

A participação dos doadores no estudo foi voluntária, atestada pela assinatura de Termo de Consentimento Livre Esclarecido. Os resultados dos exames foram enviados pelo correio a todos os doadores, conforme lhes foi informado na coleta. 


\subsection{Análise dos metais em sangue}

\subsubsection{Determinação de chumbo e cádmio}

Como já descrito no item 4.2, foi desenvolvido um novo método para a determinação simultânea de chumbo e cádmio, cujos LQ atendessem o objetivo do projeto, isto é, níveis baixos suficientes para determinar concentrações desses metais em sangue de população sem exposição ocupacional. Apesar de que somente o LQ do Cd ter sido inadequado no método utilizado no estudo piloto, o novo método desenvolvido foi baseado no anterior que permite a determinação simultânea de chumbo e cádmio, pois permite a análise de menores volumes de amostra e a otimização de custos. O método utilizado, descrito em Kummrow et al., 2008, foi validado e publicado (Anexo I). Esse método determina simultaneamente chumbo e cádmio por espectrometria de absorção atômica em forno de grafite. O equipamento utilizado foi um SIMAA 6000 da Perkin Elmer, com amostrador automático AS 72. Todas as amostras foram analisadas pelo Setor de Análises Toxicológicas da Cetesb.

A amostra, injetada para o interior do tubo de grafite, passa por duas etapas de secagem para eliminação do solvente e, em seguida, por uma etapa de pirólise em temperatura adequada para oxidação da matéria orgânica até a completa mineralização e estabilidade das espécies de interesse. Logo após, a amostra é atomizada eletrotermicamente em forno de grafite, onde é gerado o vapor atômico no caminho óptico. A quantidade 
de energia radiante emitida por uma lâmpada do elemento de interesse é absorvida no interior do tubo de grafite. A quantidade de energia absorvida é proporcional à concentração do metal de interesse na amostra.

Para melhor estabilização dos metais analisados por esse método, utiliza-se o procedimento de modificação permanente do tubo de grafite, onde os modificadores químicos são agregados diretamente sobre a plataforma pirolítica. Essa modificação permite a determinação simultânea dos elementos estudados, pois promove maior estabilidade térmica dos metais, permitindo assim um perfeito tratamento prévio da matriz.

A seguir é descrito resumidamente o tratamento da amostra, do tubo de grafite e apresentados os dados de controle de qualidade e validação do método:

- Um volume de $200 \mu \mathrm{L}$ de sangue total é diluído em solução de 500 $\mu \mathrm{L}$ de Triton X-100 0,2\% (p/v) e ácido nítrico 2\% (v/v). É adicionado ácido tricloroacético (TCA) para precipitar as proteínas, e o sobrenadante é analisado.

- Foram usados uma mistura de $250 \mu \mathrm{g}$ de $\mathrm{W}+200 \mu \mathrm{g}$ de Rh como modificador permanente e $\mathrm{NH}_{4} \mathrm{H}_{2} \mathrm{PO}_{4}$ como modificador co-injetado.

- As massas características e os limites de detecção $(n=20 ; 3 D P)$ para o Cd e Pb foram 1.26 e 33 pg e 0,026 $\mu \mathrm{g} / \mathrm{L}$ e $0,65 \mu \mathrm{g} / \mathrm{L}$, respectivamente. O $\mathrm{LQ}$ para as análises dos doadores foi de 0,01 $\mu \mathrm{g} / \mathrm{dL}$ para o $\mathrm{Cd}$ e $0,25 \mu \mathrm{g} / \mathrm{dL}$ para $\circ \mathrm{Pb}$.

- A repetibilidade variou de 1,8 a $6,8 \%$ para o $\mathrm{Cd}$ e 1,2 a 1,7\% para o $\mathrm{Pb}$. 
- A precisão do método foi checado pela análise de 3 Materiais de Referência: Lyphocheck ${ }^{\circledR}$ Whole Blood Metals Control level 1 and Seronorm $^{\mathrm{TM}}$ Trace Elements in Whole Blood levels 1 e 2. As concentrações encontradas não apresentaram diferenças estatísticas ao nível de confiança de 95\%.

O Laboratório do Setor de Análises Toxicológicas da Cetesb participa desde 2005, do Programa de Ensaio de Proficiência para Chumbo em Sangue do Instituto Adolfo Lutz (IAL), habilitado pela ANVISA/REBLAS (Agência Nacional de Vigilância Sanitária/Rede Brasileira de Laboratórios Analíticos em Saúde). O desempenho do laboratório é satisfatório em todos os critérios estatísticos avaliados pelo $\mathrm{IAL}$, estando a exatidão dos resultados em plena concordância com os valores de referência, estatisticamente reportados pelo IAL.

Além dos controles de qualidade já citados, a UBA analisou também $\mathrm{Pb}$ e $\mathrm{Cd}$ em 112 amostras selecionadas aleatoriamente entre as enviadas para análise de mercúrio, e os resultados foram comparados com os da Cetesb. O objetivo dessa comparação foi complementar o controle de qualidade analítica do chumbo, pois o interlaboratorial do IAL contempla apenas o $\mathrm{Pb}$ e ainda para níveis mais elevados do que os encontrados em sangue de população sem exposição ocupacional e, no caso do $\mathrm{Cd}$, para controle de qualidade já que a Cetesb não participa de interlaboratorial para este metal na matriz sangue. Os resultados mostraram-se satisfatórios conforme mostra a Tabela 3. A diferença observada no número de amostras 
analisadas $(\mathrm{n})$ dos dois laboratórios,. deve-se a problemas técnicos que inviabilizam a análise de algumas amostras, como por exemplo a coagulação do sangue.

Tabela 3 - Comparação dos resultados das análises de chumbo e cádmio em amostras de sangue $(\mu \mathrm{g} / \mathrm{L})$, realizadas nos laboratórios da UBA e da Cetesb

\begin{tabular}{ccccccccc}
\hline Metais & LQ & N & P10 & P50 & P95 & MAX & MG & IC95\% \\
\hline Chumbo & & & & & & & & \\
UBA & 2,10 & 108 & 13,60 & 25,40 & 56,30 & 70,20 & 24,60 & $22,40-27,00$ \\
Cetesb & 2,50 & 112 & 13,80 & 24,40 & 51,60 & 81,30 & 24,40 & $22,40-26,50$ \\
\hline Cádmio & & & & & & & & \\
UBA & 0,12 & 108 & $<0,12$ & $<0,12$ & 0,30 & 1,30 & $<0,12$ & \\
Cetesb & 0,12 & 112 & $<0,12$ & 0,15 & 0,42 & 1,47 & 0,15 & $0,13-0,16$ \\
\hline
\end{tabular}

LQ: Limite de Quantificação

P10, P50, P95: Percentis 10, 50 e 95

MAX: Valor máximo

MG: Média Geométrica

IC95\%: Intervalo de Confiança de 95\% da Média Geométrica

\subsubsection{Determinação de mercúrio total}

As análises de Hg foram realizadas pela Agência Ambiental Federal da Alemanha em Berlim como atividade integrante do acordo de cooperação entre a UBA e a Cetesb. Antes do início do presente projeto, foi realizada uma visita técnica à agência ambiental da Alemanha, onde foram contatadas a Dra. Kerstin Becker e Dra. Margarete Seiwert, pesquisadoras do GerES. Essa visita resultou em uma cooperação cujas atividades incluem análise de Hg pela UBA, compromisso de discussão dos resultados em workshop a ser 
realizado em São Paulo e de publicação conjunta com os pesquisadores da Faculdade de Medicina da USP, UBA e Cetesb que participaram do estudo. A determinação das concentrações de mercúrio no sangue foi feita por espectrometria de absorção atômica por vaporização a frio (sem chama), após pré-concentração em gaze de ouro-platina. Os resultados foram avaliados pelo procedimento de adição padrão. O LQ foi de $0,02 \mu \mathrm{g} / \mathrm{dL}$ e as taxas de recuperação ${ }^{2}$ variaram de 60 a $80 \%$. O controle da qualidade analítica foi assegurado pela utilização de materiais de referência como sangue total humano liofilizado (Seronorm ${ }^{\circledR}$ TE Whole Blood Level I e II da Immuno, Heidelberg).

\subsection{Tratamento dos dados/Análise estatística}

Os dados do questionário foram introduzidos em um banco de dados através do software EpiData e conferidos por meio de dupla digitação. O banco foi convertido para SPSS versão 13.0 para realização da análise estatística.

Para descrever a população estudada foram consideradas as seguintes variáveis: sexo, faixa etária, escolaridade, renda per capita e hábitos (consumos de pescado e bebida alcóolica, origem da água de beber,

\footnotetext{
${ }^{2}$ A recuperação mede a eficiência do procedimento de extração de um método analítico. Este teste deve ser realizado comparando-se os resultados analíticos de amostras extraídas a partir de três concentrações (baixa, média e alta) com os resultados obtidos com soluções padrões não extraídos, que representam $100 \%$ de recuperação (Brasil, 2003; INMETRO 2007).
} 
cultivo de horta na residência, tempo da última doação de sangue e total de doações). Os doadores foram distribuídos por posto de coleta e por município de residência.

\subsubsection{Valores de referência para chumbo, cádmio e mercúrio}

O indicador escolhido foi o percentil 95 (P95), isto é, os valores de referência a serem propostos serão os limites superiores dos IC95\% dos P95. Como esse indicador pressupõe normalidade, foram testadas as distribuições das concentrações dos metais no sangue quanto à normalidade. Como as distribuições foram assimétricas, foi feita uma transformação dos dados para logaritmos naturais ( $\mathrm{LnPb}, \mathrm{LnCd}$ e $\mathrm{LnHg})$.

Um Modelo Linear Geral foi ajustado tendo como variáveis resposta as concentrações de metais no sangue, e como fatores fixos o sexo e a faixa etária. A estatística empregada para avaliar a influência do sexo e da faixa etária foi $\lambda$ de Wilk's. Uma vez identificada a influência do fator, a estatística de F-Fisher foi empregada para identificar qual metal foi influenciado pelo sexo e pela faixa etária. Toda a análise é multivariada, ou seja, garante-se o nível de significância conjunto para todas as inferências.

Intervalos de $95 \%$ de Confiança foram elaborados para o P95 e para as concentrações médias. Para o cálculo dos percentis foi ajustada uma distribuição aos dados, os parâmetros dessa distribuição (média e desvio) foram obtidos pelos estimadores de Máxima Verossimilhança. 


\subsubsection{Análise univariada}

Para verificar a relação entre as variáveis dependentes e as independentes, procedeu-se à análise univariada por meio de análise de regressão linear, mas somente para as variáveis dependentes $\mathrm{LnPb}$ e $\mathrm{LnHg}$ pois, muitos valores de Cd estiveram abaixo do LQ.

A análise de regressão univariada foi feita entre as variáveis dependentes $\mathrm{LnPb}$ e $\mathrm{LnHg}$ e cada um dos seguintes fatores: sexo, faixa etária, escolaridade, freqüência de consumo de pescado, freqüência de consumo de bebida alcoólica, origem da água de beber, uso de medicamento, hábito de mascar chiclete, portador de restauração de amálgama, reformou a casa recentemente, horta na residência, proximidade da residência com fábrica, renda per capita, estado civil, tempo da última doação, total de doações e pressão arterial. Algumas variáveis apresentaram $\mathrm{n}$ insuficiente ou os grupos eram muito heterogênios para realizar a análise, por exemplo, a variável consumo de produtos da horta (sim: $n=22$ e não: $n=1$ ).

Foi feito o teste de correlação de Pearson para verificar a correlação entre os $\mathrm{LnPb}, \mathrm{LnCd}$ e $\mathrm{LnHg}$ no sangue e a porcentagem de hematócrito. 


\subsubsection{Análise de regressão linear múltipla}

Foi feita a análise de regressão linear múltipla para selecionar os fatores que mais influenciam e avaliar as contribuições independentes para as concentrações de $\mathrm{Pb}$ e $\mathrm{Hg}$ em sangue após ajuste de potenciais fatores de confusão. Entraram nessa análise somente as variáveis independentes que apresentaram na análise univariada correlação com as variáveis dependentes a um nível de significância menor ou igual a $20 \%(p \leq 0,20)$. As variáveis foram então introduzidas uma a uma no modelo e somente aquelas que eram preditivas das concentrações dos metais a um nível de significância de $\alpha \leq 0,05$ é que foram mantidas. A significância do modelo com a introdução de cada variável foi verificada por meio do Teste da Razão de Verossimilhança. Porém, a variável escolaridade não se mostrou significativa $(p=0,052)$ para $\mathrm{Pb}$, mas por ter apresentado uma significância muito próxima de 0,05 e dados de literatura indicarem a importância deste fator para concentrações de $\mathrm{Pb}$ em sangue, ela foi mantida no modelo.

O nível de significância adotado no estudo foi de 5\%. 


\section{RESULTADOS}

\subsection{População estudada}

No total foram coletadas 653 amostras de sangue, porém 114 não puderam ser analisadas para $\mathrm{Pb}$ e $\mathrm{Cd}$, e 60 para $\mathrm{Hg}$. Portanto, foram analisadas 539 amostras para $\mathrm{Pb}$ e $\mathrm{Cd}$ e 593 para $\mathrm{Hg}$. O principal motivo das perdas foi a coagulação de algumas amostras de sangue, o que impossibilitou a sua análise. Outro motivo foi que aquelas que tiveram resultado positivo no teste sorológico realizado pela Colsan, 25 amostras, não puderam ser enviadas à Alemanha, o que levou à não realização da determinação de mercúrio nas mesmas. Outros fatores técnico-analíticos também inviabilizaram algumas análises, por exemplo, 17 amostras não tiveram resultados do teste sorológico e também não foram enviadas à Alemanha. Por essa razão, o total de amostras com resultados para chumbo e cádmio foi diferente daquele com resultados para mercúrio. Com intuito de analisar as perdas e verificar a ocorrência de viés na amostragem, foi aplicado teste estatístico para verificar as diferenças entre os estratos da amostra e das perdas (Tabela 4). A tabela mostra que houve uma diferença apenas para chumbo e cádmio em relação a sexo. Houve mais homens na amostra enquanto houve mais perdas de mulheres. 
Tabela 4 - Número de indivíduos que tiveram amostras de sangue analisadas quanto ao conteúdo de $\mathrm{Pb}, \mathrm{Cd}$ e $\mathrm{Hg}$, e número de perdas, segundo sexo e faixa etária

\begin{tabular}{|c|c|c|c|c|c|c|}
\hline & \multicolumn{3}{|c|}{ CHUMBO e CÁDMIO } & \multicolumn{3}{|c|}{ MERCÚRIO } \\
\hline & $\begin{array}{l}\text { Amostras } \\
\text { analisadas }\end{array}$ & Perdas & $p$ & $\begin{array}{c}\text { Amostras } \\
\text { analisadas }\end{array}$ & Perdas & $P$ \\
\hline & N (\%) & N (\%) & & N (\%) & N (\%) & \\
\hline \multicolumn{7}{|l|}{ SEXO } \\
\hline Masculino & $316(58,6)$ & $48(42,1)$ & 0,001 & $328(55,3)$ & $36(60)$ & 0,486 \\
\hline Feminino & $223(41,4)$ & $66(57,9)$ & & $265(44,7)$ & $24(40)$ & \\
\hline \multicolumn{7}{|l|}{ IDADE } \\
\hline $18-39$ & $392(72,7)$ & $74(64,9)$ & 0,094 & $419(70,7)$ & $47(78,3)$ & \\
\hline $40-65$ & $147(27,3)$ & $40(35,1)$ & & $174(29,3)$ & $13(21,7)$ & 0,210 \\
\hline TOTAL & 539 & 114 & & 593 & 60 & \\
\hline
\end{tabular}

A Tabela 5 mostra a distribuição da população estudada por posto da Colsan. Devido ao número muito reduzido de doadores que procuravam o Posto São Caetano, decidiu-se por excluí-lo. Portanto, somente 9 postos participaram do estudo.

Tabela 5 - Distribuição dos doadores pesquisados, segundo posto de coleta da Colsan localizados na RMSP. Novembro de 2006

\begin{tabular}{lccc}
\hline & HOMENS & MULHERES & TOTAL \\
POSTo & $\mathrm{N}(\%)$ & $\mathrm{N}(\%)$ & $\mathrm{N}(\%)$ \\
\hline C. Limpo & $25(6,9)$ & $35(12,1)$ & $60(9,2)$ \\
E. Matarazzo & $6(1,6)$ & $2(0,7)$ & $8(1,2)$ \\
Ipiranga & $21(5,8)$ & $13(4,5)$ & $34(5,2)$ \\
Sto André I & $173(47,5)$ & $119(41,2)$ & $292(44,7)$ \\
Sto André II & $8(2,2)$ & $4(1,4)$ & $12(1,8)$ \\
S. Bernardo & $36(9,9)$ & $35(12,1)$ & $71(10,9)$ \\
Tatuapé & $38(10,4)$ & $33(11,4)$ & $71(10,9)$ \\
T. Setúbal & $4(1,1)$ & $5(1,7)$ & $9(1,4)$ \\
Vergueiro & $53(14,6)$ & $43(14,9)$ & $96(14,7)$ \\
\hline TOTAL & $364(100)$ & $289(100)$ & $653(100)$ \\
\hline
\end{tabular}


Os doadores eram de ambos os sexos, com idades entre 18 e 65 anos e residentes na RMSP. Houve um doador que na data da coleta já tinha completado 66 anos. As características gerais da população estudada estão dispostas na Tabela 6.

Tabela 6 - População estudada, segundo faixa etária (anos), nível de escolaridade e renda per capita (reais)

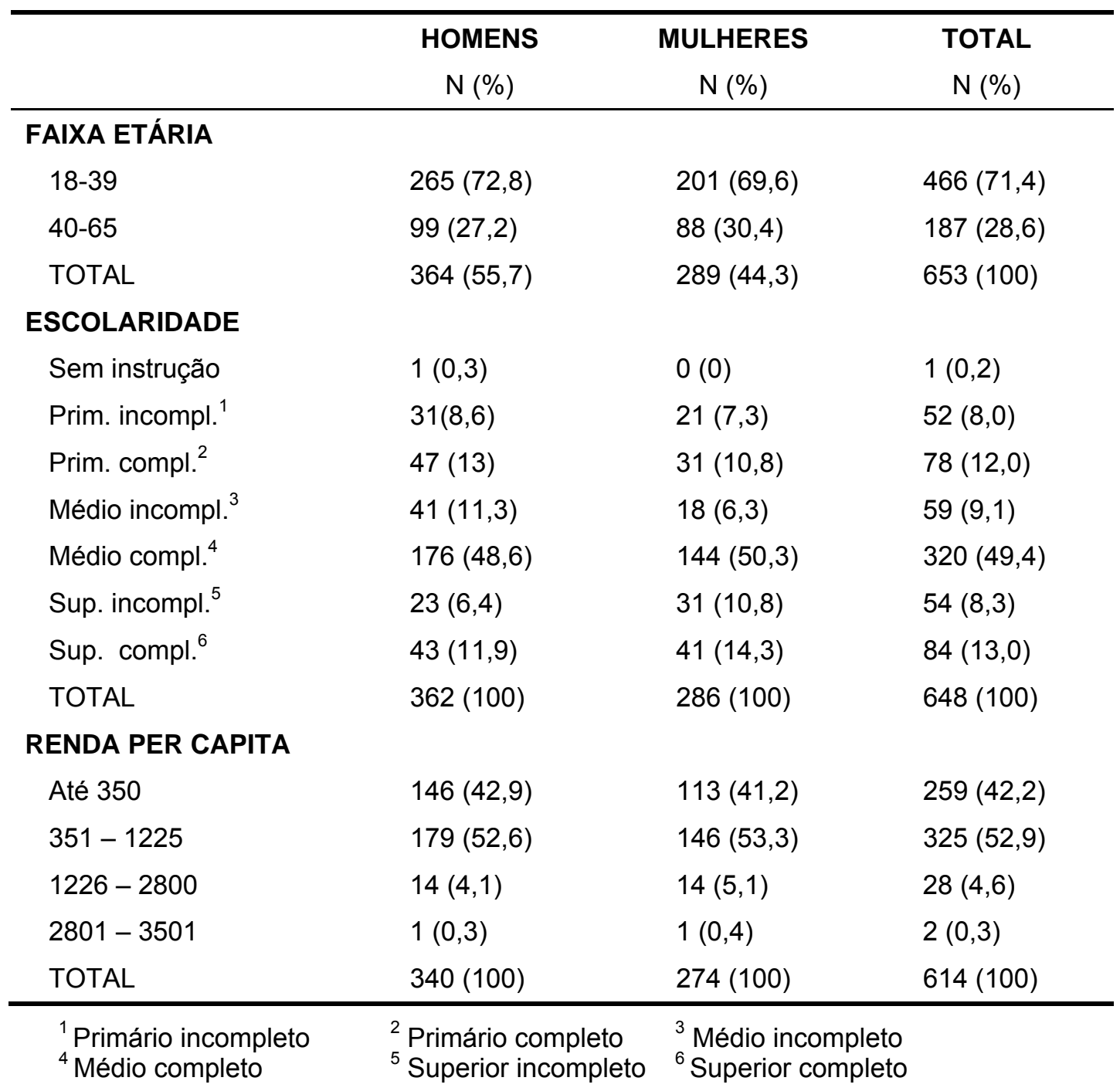


Os doadores de sangue que participaram da pesquisa residiam em 18 municípios da RMSP (Tabela 7). Nota-se uma predominância no município de São Paulo, seguido por São Bernardo do Campo e Santo André.

Tabela 7 - Distribuição dos doadores segundo município de residência

\begin{tabular}{llll}
\hline \multicolumn{1}{c}{ MUNICÍPIO } & $\begin{array}{l}\text { HOMENS } \\
\text { N (\%) }\end{array}$ & $\begin{array}{c}\text { MULHERES } \\
\text { N (\%) }\end{array}$ & $\begin{array}{l}\text { TOTAL } \\
\text { N (\%) }\end{array}$ \\
\hline Carapicuíba & $2(0,5)$ & $0(0)$ & $2(0,3)$ \\
Cotia & $1(0,3)$ & $0(0)$ & $1(0,2)$ \\
Diadema & $23(6,3)$ & $6(2,1)$ & $29(4,4)$ \\
F. Vasconcelos & $2(0,5)$ & $1(0,3)$ & $3(0,5)$ \\
Guarulhos & $1(0,3)$ & $1(0,3)$ & $2(0,3)$ \\
Itapecerica Serra & $3(0,8)$ & $0(0)$ & $3(0,5)$ \\
Juquitiba & $1(0,3)$ & $0(0)$ & $1(0,2)$ \\
Mauá & $33(9,1)$ & $19(6,6)$ & $52(8,0)$ \\
Poá & $0(0)$ & $2(0,7)$ & $2(0,3)$ \\
Ribeirão Pires & $10(2,7)$ & $5(1,7)$ & $15(2,3)$ \\
Rio Grande Serra & $6(1,6)$ & $3(1)$ & $9(1,4)$ \\
Santana Parnaíba & $0(0)$ & $1(0,3)$ & $1(0,2)$ \\
Sto André & $49(13,5)$ & $39(13,5)$ & $88(13,5)$ \\
São Bernardo & $66(18,1)$ & $50(17,3)$ & $116(17,8)$ \\
São Caetano & $6(1,6)$ & $7(2,4)$ & $13(2,0)$ \\
São Paulo & $156(42,9)$ & $154(53,3)$ & $310(47,5)$ \\
Suzano & $4(1,1)$ & $1(0,3)$ & $5(0,8)$ \\
Taboão Serra & $1(0,3)$ & $0(0)$ & $1(0,2)$ \\
\hline TOTAL & $364(100)$ & $289(100)$ & $653(100)$ \\
\hline
\end{tabular}




\subsection{Resultados de metais em sangue}

Verificação da hipótese de normalidade dos dados de concentração dos metais em sangue

Face à assimetria observada na distribuição das concentrações dos metais em sangue (Figura 7), foi feita a transformação logarítmica dos dados. Após a transformação, o chumbo e o mercúrio aderiram perfeitamente à distribuição normal, os pequenos desvios observados não afetam o indicador escolhido na pesquisa, o percentil 95\% (Figura 8). Porém, as concentrações de cádmio, mesmo transformadas, não seguiram o padrão da distribuição Normal ou Gaussiana. Assim, para o cádmio foi necessário utilizar-se de procedimento adicional, descrito no próximo item. 

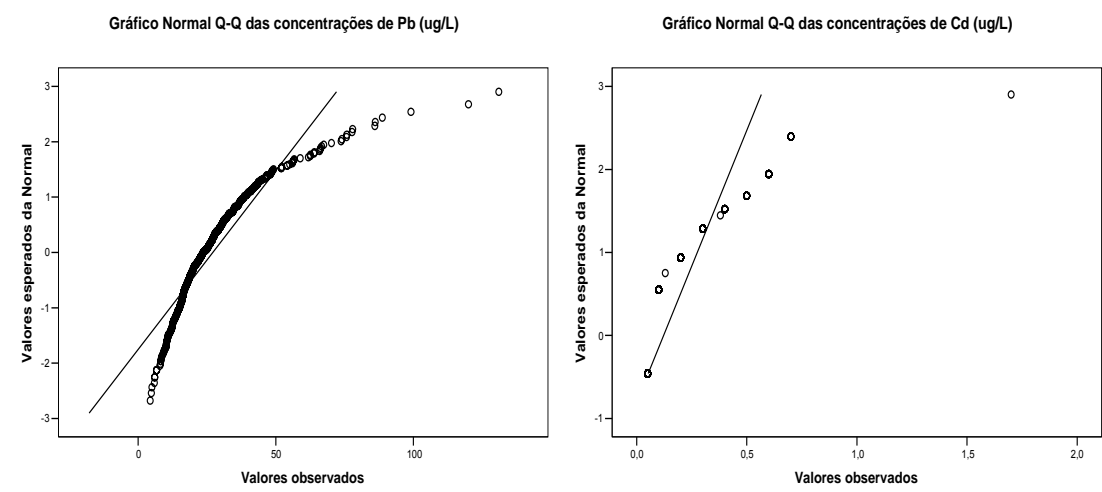

Gráfico Normal Q-Q das concentrações de Hg (ug/L)

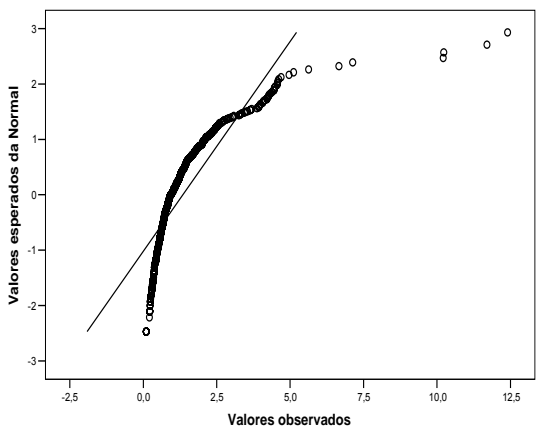

Figura 7 - Gráfico dos Quantis da distribuição Normal x Concentrações de metais sem transformação para logaritmo natural
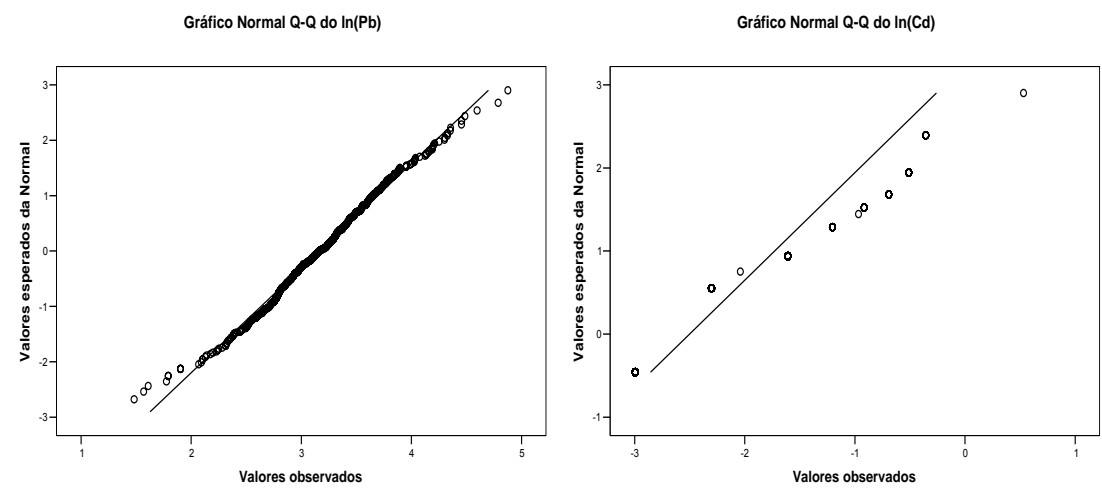

Gráfico Normal Q-Q de $\ln (\mathrm{Hg})$

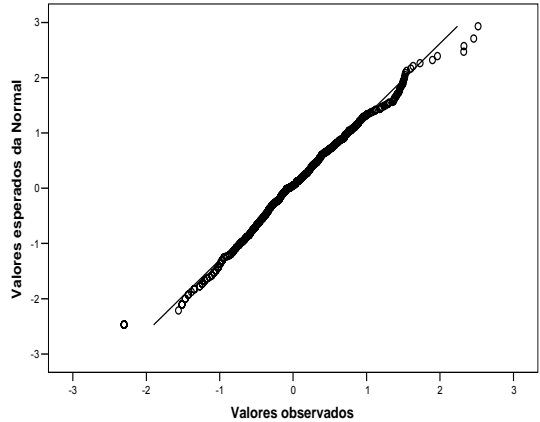

Figura 8 - Gráfico dos Quantis da distribuição Normal x Concentrações de metais transformados em logaritmo natural 


\section{Avaliação das concentrações de cádmio}

Mesmo com a utilização de um método analítico mais sensível, foi grande o número de indivíduos que apresentaram valores de cádmio inferiores ao limite de quantificação do método, 348 do total de 539 com dados válidos, correspondendo a $65 \%$ dos doadores. Nas Figuras 7 e 8 , os gráficos de cádmio foram construídos usando o valor de $0,05 \mu \mathrm{g} / \mathrm{L}$, que corresponde à metade do limite de quantificação do método, para as concentrações de $\mathrm{Cd}$ que ficaram abaixo do LQ. Esse procedimento é bastante usado, mas quando a porcentagem de valores abaixo do LQ é muito elevada, como é o caso, ainda assim podem ocorrer distorções, como a observada.

A Figura 9 mostra as distribuições do logaritmo natural das concentrações observadas do Cd. Nos dois primeiros gráficos (A e B) foram incluídas as concentrações de toda a população estudada e nos outros (C e D) somente as concentrações de cádmio superiores ao LQ que é $0,1 \mu \mathrm{g} / \mathrm{L}$. Observa-se que o ajuste à distribuição normal fica melhor nas distribuições onde foram incluídos somente os valores acima do LQ (C e D). Nota-se também que esse ajuste é melhor nos percentis mais elevados, lembrando aqui, que nosso objetivo que é estimar o P95. 
A

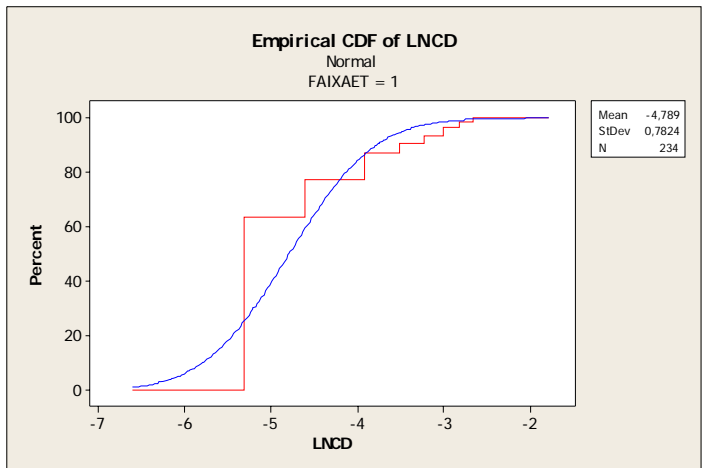

C

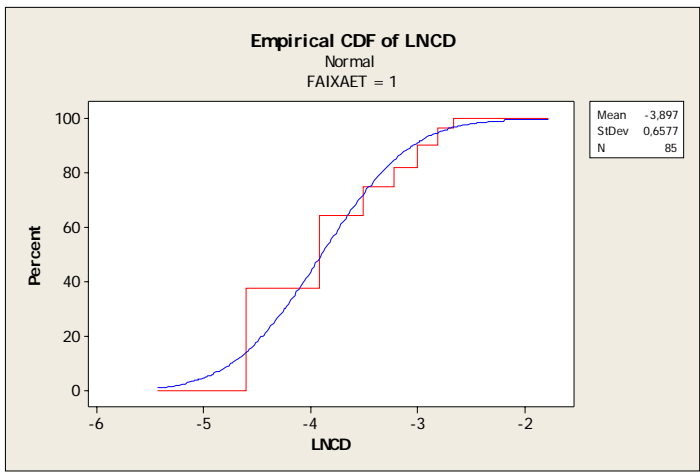

B

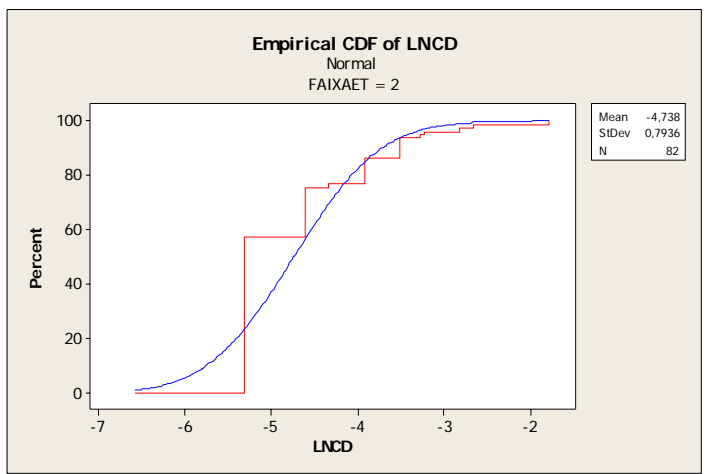

D

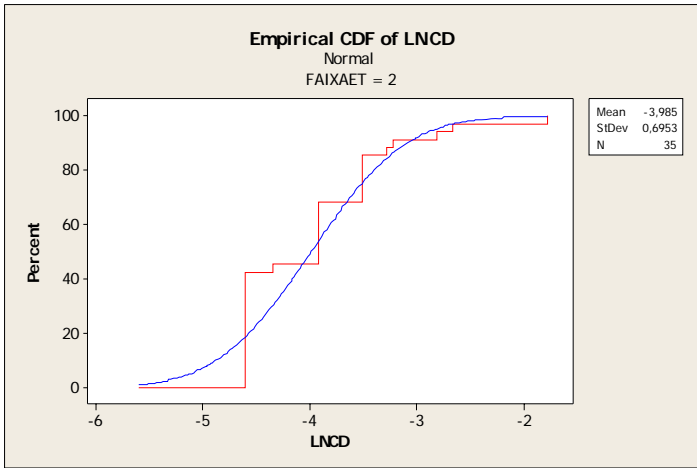

Figura 9 - Distribuições dos logaritmos naturais das concentrações de cádmio para as duas faixas etárias, de toda população estudada (A e B) e somente das concentrações acima do limite de quantificação (C e D)

Esse fato caracteriza essa distribuição como Truncada no limite de detecção do método. Como conseqüência, podemos estimar o P95 da distribuição global (todos os dados), com base na soma do valor do limite (=P65) com o P30 da distribuição dos dados acima do limite. A soma é exatamente o percentil desejado, ou seja, $95 \%$ dos dados estarão abaixo desse valor. 
Utilizando apenas os dados observados acima do limite de quantificação do método de análise do $\mathrm{Cd}$, procedeu-se ao ajuste da distribuição dos dados ${ }^{3}$. Como mostra a Figura 10, para esse conjunto de dados, acima do LQ, a hipótese de normalidade pode ser assumida. O indicador escolhido P95 foi obtido a partir dessa distribuição ajustada. Isto é, os dados reais compreendiam $100 \%$ da distribuição, porém $65 \%$ dos valores estiveram abaixo do $L Q$, não sendo possível saber as verdadeiras concentrações de $65 \%$ da distribuição.

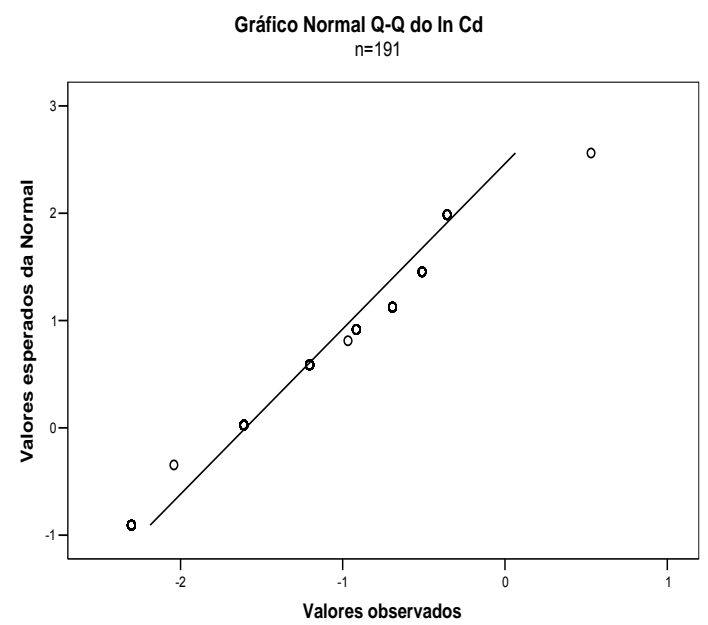

Figura 10 - Quantis da distribuição Normal x concentrações de Cd acima do Limite de Quantificação

\footnotetext{
${ }^{3}$ A distribuição ajustada garante a robustez para a estimativa desejada (P95), p.ex. se na amostra existissem indivíduos com histórico de exposição, esse viés seria eliminado, caso contrário, comprometeria o P95 da distribuição bruta.
} 


\section{Concentrações de $\mathrm{Pb}, \mathrm{Cd}$ e $\mathrm{Hg}$ no sangue}

A Tabela 8, mostra a distribuição das concentrações $(\mu \mathrm{g} / \mathrm{L})$ de $\mathrm{Pb}, \mathrm{Cd}$ e Hg no sangue da amostra estudada.

Tabela 8 - Distribuição das concentrações $(\mu \mathrm{g} / \mathrm{L})$ de $\mathrm{Pb}, \mathrm{Cd}$ e $\mathrm{Hg}$ no sangue da população estudada

\begin{tabular}{lccc}
\hline & Chumbo & Cádmio & Mercúrio \\
\hline $\mathrm{N}$ & 539 & 539 & 593 \\
Média $^{1}$ & 27,1 & 0,10 & 1,40 \\
$\mathrm{DP}^{2}$ & 15,5 & 0,15 & 1,40 \\
MG $^{3}$ & & & \\
Masc & 28,0 & 0,08 & 0,95 \\
Fem & 18,6 & 0,10 & 1,07 \\
Total & 23,7 & 0,08 & 0,98 \\
IC95 $^{4}$ & $22,4-24,7$ & $0,08-0,09$ & $0,90-1,05$ \\
Mínimo & 1,3 & 0,05 & 0,10 \\
Máximo & 131,0 & 1,70 & 12,40 \\
N<LQ & 5 & 348 & 9 \\
\hline
\end{tabular}

${ }^{1}$ Média aritmética dos dados brutos, sem transformação para logaritmo natural

${ }^{2}$ Desvio padrão da média aritmética

${ }^{3}$ Média geométrica

${ }^{4}$ Intervalo de $95 \%$ confiança da média geométrica total

${ }^{5}$ Resultados abaixo do limite de quantificação 


\section{Associação das concentrações de chumbo e mercúrio com as variáveis independentes}

Para verificar a relação entre as variáveis dependentes e as independentes, procedeu-se à análise univariada por meio de regressão linear, mas somente para as variáveis dependentes $\mathrm{LnPb}$ e $\mathrm{LnHg}$, uma vez que muitos valores de Cd ficaram abaixo do LQ.

As Tabelas 9 e 10 mostram a relação de potenciais determinantes com as concentrações de chumbo e mercúrio em sangue, respectivamente. Os dados apresentados correspondem aos exponenciais do logaritmo natural. Como mostra a Tabela 9, os fatores que apresentaram associação significativa $(p \leq 0,05)$ com chumbo em sangue foram sexo, faixa etária, escolaridade, consumo de bebida alcoólica, mascar chiclete (quem não masca tem valor maior de $\mathrm{Pb}$ ), horta na residência e pressão arterial alterada. Já as variáveis que foram significativas para $\mathrm{Hg}$ em sangue foram escolaridade, consumo de pescado, uso de remédios e presença de restauração de amálgama (Tabela 10).

Para verificar a correlação entre os metais estudados e o hematócrito, foi feito o teste de correlação de Pearson. Apenas o chumbo (InPb) apresentou correlação positiva com hematócrito $(r=0,296, p<0,001)$. 
Tabela 9 - Relação de potenciais determinantes com concentração de chumbo em sangue: Estimativa do parâmetro, Erro padrão, IC95\% da Estimativa do parâmetro e significância $(p)$ na Regressão Linear Univariada

\begin{tabular}{|c|c|c|c|c|}
\hline Variáveis & $\begin{array}{l}\text { Estimativa do } \\
\text { parâmetro }\end{array}$ & Erro Padrão & IC95\% & $\boldsymbol{P}$ \\
\hline \multicolumn{4}{|l|}{ SEXO } & \multirow[t]{3}{*}{$<0,001$} \\
\hline Masculino & 1,505 & 0,043 & $1,384-1,637$ & \\
\hline Feminino & Referência & & & \\
\hline \multicolumn{4}{|l|}{ Faixa etária } & \multirow[t]{3}{*}{$<0,001$} \\
\hline 18-39 & Referência & & & \\
\hline $40-65$ & 1,209 & 0,051 & $1,094-1,335$ & \\
\hline \multicolumn{4}{|l|}{ Escolaridade } & \multirow[t]{4}{*}{0,015} \\
\hline Primário & 1,281 & 0,07 & $1,115-1,471$ & \\
\hline Médio & 1,105 & 0,058 & $0,986-1,240$ & \\
\hline Superior & Referência & & & \\
\hline \multicolumn{4}{|l|}{ Consumo pescado } & \multirow[t]{6}{*}{0,977} \\
\hline Diariamente e (+ 1x semana) & 1,138 & 0,121 & $0,898-1,442$ & \\
\hline 1xsemana & 1,053 & 0,076 & $0,907-1,224$ & \\
\hline 2 a 3 x mês & 1,084 & 0,083 & $0,921-1,275$ & \\
\hline $1 \times$ mês & 1,026 & 0,062 & $0,908-1,160$ & \\
\hline Não come & Referência & & & \\
\hline \multicolumn{4}{|l|}{ Consumo bebida alcoólica } & \multirow[t]{4}{*}{0,048} \\
\hline Diariamente & 1,508 & 0,109 & $1,218-1,870$ & \\
\hline Fim de semana & 1,154 & 0,047 & $1,051-1,266$ & \\
\hline Não bebe & Referência & & & \\
\hline \multicolumn{4}{|l|}{ Água de beber } & \multirow[t]{4}{*}{0,773} \\
\hline Mineral & 1,040 & 0,05 & $0,942-1,147$ & \\
\hline Poço & 1,404 & 0,12 & $1,110-1,775$ & \\
\hline Rede de distribuição pública & Referência & & & \\
\hline \multicolumn{4}{|l|}{ Uso de remédios } & \multirow[t]{3}{*}{0,282} \\
\hline $\mathrm{Sim}$ & 0,943 & 0,055 & $0,846-1,050$ & \\
\hline Não & Referência & & & \\
\hline \multicolumn{4}{|l|}{ Masca chiclete } & \multirow[t]{3}{*}{0,002} \\
\hline Sim & 0,866 & 0,046 & $0,791-0,948$ & \\
\hline Não & Referência & & & \\
\hline \multicolumn{4}{|l|}{ Restauração de amálgama } & \multirow[t]{3}{*}{0,345} \\
\hline Sim & 0,952 & 0,051 & $0,861-1,053$ & \\
\hline Não & Referência & & & \\
\hline \multicolumn{4}{|l|}{ Reforma } & \multirow[t]{3}{*}{0,691} \\
\hline $\operatorname{Sim}$ & 1,019 & 0,048 & $0,928-1,119$ & \\
\hline Não & Referência & & & \\
\hline
\end{tabular}


Conclusão Tabela 9

\begin{tabular}{|c|c|c|c|c|}
\hline Variáveis & $\begin{array}{c}\text { Estimativa do } \\
\text { parâmetro }\end{array}$ & Erro Padrão & IC95\% & $P$ \\
\hline Horta & & & & 0,030 \\
\hline $\begin{array}{l}\text { Sim } \\
\text { Não }\end{array}$ & $\begin{array}{c}1,280 \\
\text { Referência }\end{array}$ & 0,113 & $1,024-1,598$ & \\
\hline Fábrica & & & & 0,332 \\
\hline Sim & 0,952 & 0,051 & $0,862-1,051$ & \\
\hline Não & Referência & & & \\
\hline Renda & & & & 0,128 \\
\hline até 350 & 1,171 & 0,113 & 0,938-1,461 & \\
\hline $351-1225$ & 1,095 & 0,112 & $0,879-1,363$ & \\
\hline$>1226$ & Referência & & & \\
\hline Estado civil & & & & 0,359 \\
\hline Casado & Referência & & & \\
\hline Solteiro, viúvo, separado & 0,959 & 0,046 & $0,876-1,049$ & \\
\hline Tempo da última doação & & & & 0,075 \\
\hline Primeira vez & 0,921 & 0,046 & $0,841-1,008$ & \\
\hline$>3$ meses & Referência & & & \\
\hline Total de doações & & & & 0,676 \\
\hline Primeira vez & 0,918 & 0,085 & $0,777-1,084$ & \\
\hline 1 a 5 & 1,010 & 0,085 & $0,855-1,195$ & \\
\hline$>5$ & Referência & & & \\
\hline Pressão arterial & & & & $<0,001$ \\
\hline Alterada & 1,224 & 0,057 & 1,095-1,369 & \\
\hline Normal & Referência & & & \\
\hline
\end{tabular}


Tabela 10 - Relação de potenciais determinantes com concentração de mercúrio em sangue: Estimativa do parâmetro, Erro padrão, IC95\% da Estimativa do parâmetro e significância $(p)$ na Regressão Linear Univariada

\begin{tabular}{|c|c|c|c|c|}
\hline Variáveis & $\begin{array}{l}\text { Estimativa do } \\
\text { parâmetro }\end{array}$ & $\begin{array}{c}\text { Erro } \\
\text { Padrão }\end{array}$ & IC95\% & $P$ \\
\hline SEXO & & & & 0,874 \\
\hline $\begin{array}{l}\text { Masculino } \\
\text { Feminino }\end{array}$ & $\begin{array}{c}0,990 \\
\text { Referência }\end{array}$ & 1,067 & $0,871-1,125$ & \\
\hline Faixa etária & & & & 0,078 \\
\hline $18-39$ & Referência & & & \\
\hline $40-65$ & 1,133 & 1,074 & $0,986-1,303$ & \\
\hline Escolaridade & & & & $<0,001$ \\
\hline Primário & 0,601 & 1,103 & $0,497-0,728$ & \\
\hline Médio & 0,669 & 1,081 & $0,574-0,780$ & \\
\hline Superior & Referência & & & \\
\hline Consumo pescado & & & & $<0,001$ \\
\hline Diariamente e $(+1 \mathrm{x}$ semana $)$ & 2,257 & 1,166 & $1,667-3,056$ & \\
\hline 1xsemana & 1,879 & 1,107 & $1,539-2,298$ & \\
\hline 2 a $3 \times$ mês & 1,726 & 1,120 & $1,384-2,153$ & \\
\hline $1 \times$ mês & 1.495 & 1.088 & $1.266-1.763$ & \\
\hline Não come & Referência & & & \\
\hline Consumo bebida alcoólica & & & & 0,177 \\
\hline Diariamente & 1,361 & 1,181 & $0,981-1,885$ & \\
\hline Fim de semana & 1,089 & 1,069 & $0,954-1,242$ & \\
\hline Não bebe & Referência & & & \\
\hline Água de beber & & & & 0,061 \\
\hline Mineral & 0,983 & 1,073 & $0,857-1,129$ & \\
\hline Poço & 1,146 & 1,179 & $0,829-1,582$ & \\
\hline Rede & Referência & & & \\
\hline Uso de remédios & & & & 0,043 \\
\hline Sim & 1,168 & 1,079 & $1,005-1,355$ & \\
\hline Não & Referência & & & \\
\hline Masca chiclete & & & & 0,731 \\
\hline Sim & 1,022 & 1,067 & $0,900-1,162$ & \\
\hline Não & Referência & & & \\
\hline Restauração de amálgama & & & & $<0,001$ \\
\hline Sim & 1,334 & 1,075 & $1,158-1,536$ & \\
\hline Não & Referência & & & \\
\hline Reforma & & & & 0,794 \\
\hline Sim & 1,017 & 1,068 & $0,893-1,160$ & \\
\hline Não & Referência & & & \\
\hline
\end{tabular}

Continua... 
Conclusão Tabela 10

\begin{tabular}{|c|c|c|c|c|}
\hline Variáveis & $\begin{array}{l}\text { Estimativa do } \\
\text { parâmetro }\end{array}$ & $\begin{array}{l}\text { Erro } \\
\text { Padrão }\end{array}$ & IC95\% & $P$ \\
\hline \multicolumn{4}{|l|}{ Horta } & \multirow[t]{3}{*}{0,386} \\
\hline Sim & 0,870 & 1,174 & $0,635-1,192$ & \\
\hline Não & Referência & & & \\
\hline \multicolumn{4}{|l|}{ Fábrica } & \multirow[t]{3}{*}{0,401} \\
\hline Sim & 1,063 & 1,075 & $0,922-1,225$ & \\
\hline Não & Referência & & & \\
\hline \multicolumn{4}{|l|}{ Renda } & \multirow[t]{4}{*}{0,180} \\
\hline até 350 & 0,647 & 1,170 & $0,475-0,880$ & \\
\hline $351-1225$ & 0,764 & 1,168 & $0,564-1,036$ & \\
\hline$>1226$ & Referência & & & \\
\hline \multicolumn{4}{|l|}{ Estado civil } & \multirow[t]{3}{*}{0,291} \\
\hline Casado & Referência & & & \\
\hline Solteiro, viúvo, separado & 0,933 & 1,067 & $0,822-1,061$ & \\
\hline \multicolumn{4}{|l|}{ Tempo da última doacão } & \multirow[t]{2}{*}{0,077} \\
\hline $\begin{array}{l}\text { Primeira vez } \\
>3 \text { meses }\end{array}$ & $\begin{array}{l}0,890 \\
0\end{array}$ & 1,068 & $0,783-1,013$ & \\
\hline \multicolumn{4}{|l|}{ Total de doacões } & \multirow[t]{4}{*}{0,676} \\
\hline Primeira vez & 0,965 & 1,129 & $0,760-1,225$ & \\
\hline 1 a 5 & 1,124 & 1,129 & $0,885-1,426$ & \\
\hline$>5$ & Referência & & & \\
\hline \multirow{3}{*}{$\begin{array}{l}\text { Pressão arterial } \\
\text { Alterada } \\
\text { Normal }\end{array}$} & & & & \multirow[t]{3}{*}{0,770} \\
\hline & 0,977 & 1,083 & $0,835-1,142$ & \\
\hline & Referência & & & \\
\hline
\end{tabular}

\section{Análise de regressão linear múltipla}

As Tabelas 11 e 12 mostram os resultados da análise de regressão linear múltipla para chumbo e mercúrio respectivamente (exponenciais de In). Foram introduzidas no modelo as variáveis que apresentaram na análise univariada o valor de $p \leq 0,20$, e permaneceram aquelas com nível de significância $\leq$ 0,05 no teste da Razão de Verossimilhança. 
Segundo o modelo (Tab. 11), as variáveis que mais contribuíram para os níveis de chumbo em sangue foram sexo, onde os homens apresentaram cerca de $50 \%$ mais chumbo em sangue do que as mulheres; e faixa etária, as pessoas com idade entre 40 e 65 anos apresentaram cerca de $23 \%$ mais chumbo em sangue quando comparadas às com idades entre 18 e 39 anos.

Para as concentrações de mercúrio em sangue (Tab. 12), a variável que mais contribuiu foi consumo de peixe, onde as pessoas que consomem peixe diariamente ou mais que uma vez por semana possuem $107 \%$ mais mercúrio em sangue quando comparadas com uma pessoa que não come peixe. Do mesmo modo, observou-se $80 \%, 60 \%$ e $45 \%$ mais mercúrio naquelas pessoas que consomem uma vez por semana, 2 a 3 vezes por mês e uma vez por mês em relação às que não comem peixe. Possuir restauração de amálgama aumentou cerca de $24 \%$ os níveis sanguíneos de mercúrio quando comparadas às pessoas que não tinham restauração e os indivíduos na faixa de idade entre 40 e 65 anos apresentaram cerca de $19 \%$ mais mercúrio em sangue do que a faixa de 18 a 39 anos.

Também em relação aos níveis de mercúrio em sangue, a variável escolaridade mostrou associação significativa, porém negativa, os indivíduos com menor grau de escolaridade apresentam menos mercúrio em sangue quando comparados com aqueles com nível superior. Pessoas com nível de escolaridade primário e médio apresentam cerca de $33 \%$ e $29 \%$ menos mercúrio em sangue do que às de nível superior. 
Tabela 11 - Resultados da regressão linear múltipla relativa à associação significativa $(p \leq 0,05)$ entre concentração de chumbo em sangue e as variáveis explicativas

\begin{tabular}{lcccc}
\hline Modelo & $\begin{array}{c}\text { Estimativa do } \\
\text { parâmetro }\end{array}$ & Erro Padrão & $\boldsymbol{p}$ & IC 95\% \\
\hline Constante & 1,752 & 1,036 & $<0,001$ & $1,636-1,876$ \\
Sexo & 1,516 & 1,043 & $<0,001$ & $1,395-1,647$ \\
Faixa etária & 1,229 & 1,048 & $<0,001$ & $1,121-1,346$ \\
\hline
\end{tabular}

Tabela 12 - Resultados da regressão linear múltipla relativa à associação significativa $(p \leq 0,05)$ entre concentração de mercúrio em sangue e as variáveis explicativas

\begin{tabular}{lcccc}
\hline \multicolumn{1}{c}{ Modelo } & $\begin{array}{c}\text { Estimativa } \\
\text { do } \\
\text { parâmetro }\end{array}$ & $\begin{array}{c}\text { Erro } \\
\text { Padrão }\end{array}$ & $\boldsymbol{p}$ & IC 95\% \\
\hline Constante & 0,074 & 1,116 & $<0,001$ & $0,060-0,092$ \\
Come peixe diariamente e (+1xsemana) & 2,073 & 1,162 & $<0,001$ & $1,545-2,784$ \\
Come peixe 1xsemana & 1,809 & 1,108 & $<0,001$ & $1,477-2,214$ \\
Come peixe 2-3xmes & 1,606 & 1,117 & $<0,001$ & $1,292-1,998$ \\
Come peixe 1xmes & 1,446 & 1,089 & $<0,001$ & $1,225-1,707$ \\
Escolaridade primário & 0,670 & 1,104 & $<0,001$ & $0,552-0,814$ \\
Escolaridade médio & 0,705 & 1,080 & $<0,001$ & $0,606-0,820$ \\
Possuir restauração de amálgama & 1,237 & 1,071 & 0,002 & $1,081-1,416$ \\
Faixa etária & 1,188 & 1,071 & 0,013 & $1,037-1,359$ \\
\hline
\end{tabular}




\section{Análise Multivariada para avaliação dos efeitos do sexo e faixa etária sobre as concentrações de metais no sangue}

Foram ajustados Modelos Lineares Gerais ${ }^{4}$ para avaliação conjunta dos possíveis efeitos do sexo e faixa etária dos doadores sobre as concentrações dos metais pesquisados, $\mathrm{Pb}, \mathrm{Cd}$ e $\mathrm{Hg}$.

A Tabela 13 apresenta as estatísticas relativas ao ajuste do modelo linear geral para o chumbo. $O$ resultado desse ajuste foi que sexo e faixa etária constituem fatores significativos para a concentração de chumbo no sangue dos doadores, e não foi detectada influência da interação entre sexo e faixa etária $(p=0,745)$. Portanto, as mulheres apresentaram concentrações significativamente inferiores de chumbo e houve aumento significativo nos níveis de $\mathrm{Pb}$ no sangue com o aumento da idade. Na Figura 11 estão representadas as médias geométricas observadas de chumbo $(\mu \mathrm{g} / \mathrm{L})$ por sexo e faixa etária.

${ }^{4}$ O Modelo Linear Geral (MLG) é a generalização de diversos testes: teste-t, Análise de Variância (ANOVA), Análise de Covariância (ANCOVA), análise de regressão, e muitos dos métodos multivariados. Fazendo uma analogia com o modelo linear bivariado que descreve o relacionamento entre 2 variáveis, mostrando os padrões gerais dos dados de maneira mais concisa do que permite olhando-se a distribuição inteira, o MLG usa a mesma equação da bivariada, porém possibilita a análise de grupos de variáveis, não apenas uma. O MLG permite resumir uma grande variedade de resultados de pesquisa (Trochim, 2006). 
Tabela 13 - Relacionamento das variáveis sexo e faixa etária com os níveis de chumbo no sangue

\begin{tabular}{lccccc}
\hline Fonte de variação & $\begin{array}{c}\text { Soma de } \\
\text { Quadrados }\end{array}$ & gl & $\begin{array}{c}\text { Quadrado } \\
\text { Médio }\end{array}$ & F & Sig. \\
\hline Modelo & 26,442 & 3 & 8,814 & 37,974 & $<0,001$ \\
Intercepto & 318,101 & 1 & 318,101 & 1370,509 & $<0,001$ \\
Faixa etária & 4,351 & 1 & 4,351 & 18,747 & $<0,001$ \\
Sexo & 18,709 & 1 & 18,709 & 80,604 & $<0,001$ \\
Interação SxFE & 0,025 & 1 & 0,025 & 0,106 & 0,745 \\
Erro & 124,176 & 535 & 0,232 & & \\
\hline Total & 549,793 & 539 & & & \\
\hline
\end{tabular}

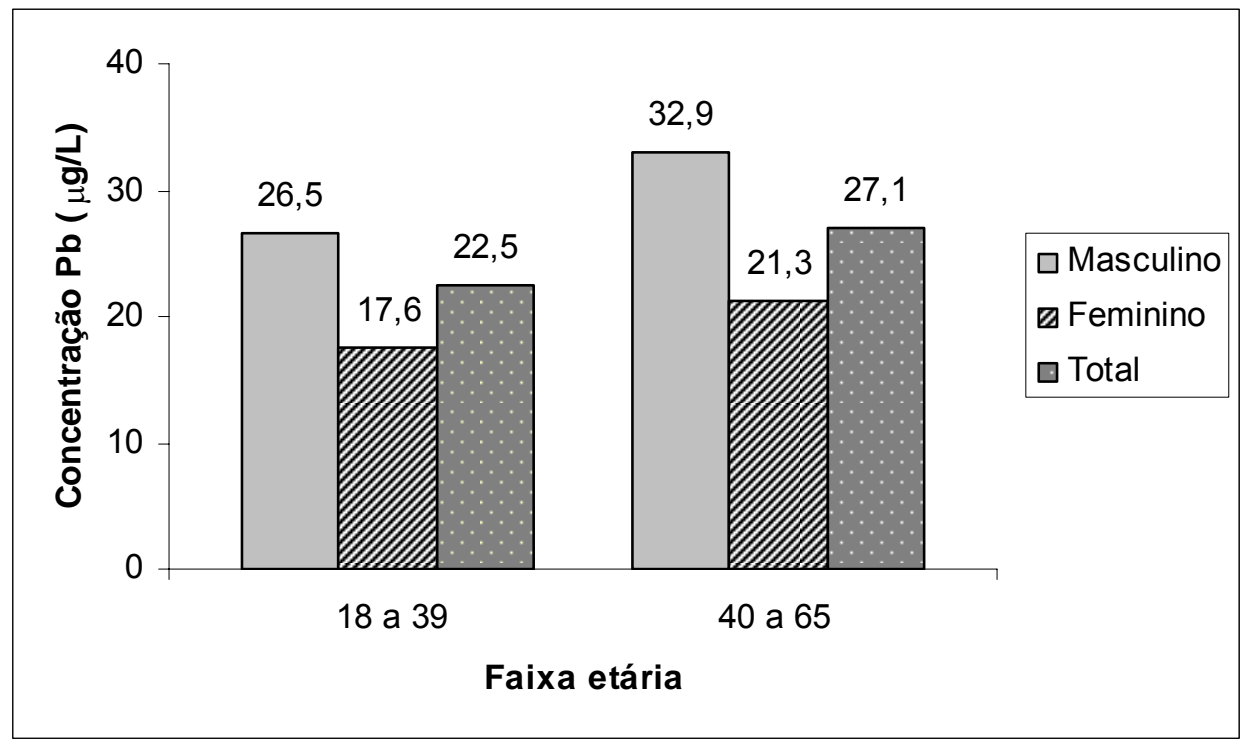

Figura 11 - Médias geométricas de chumbo em sangue ( $\mu \mathrm{g} / \mathrm{L})$ da população estudada, segundo sexo e faixa etária.

A Tabela 14 apresenta as estatísticas relativas ao ajuste do modelo linear geral para o mercúrio. Os resultados do ajuste do modelo apontaram haver indícios $(p=0,078)$ de que somente a faixa etária teria influência sobre 
as concentrações de mercúrio no sangue, o sexo não apresentou influência sobre as concentrações desse metal. Assim, as concentrações de mercúrio no sangue aumentam com a idade da pessoa, isto independentemente do seu sexo. A Figura 12 apresenta as médias geométricas observadas de mercúrio $(\mu \mathrm{g} / \mathrm{L})$ por sexo e faixa etária.

Tabela 14 - Relacionamento das variáveis sexo e faixa etária com os níveis de mercúrio no sangue

\begin{tabular}{lccccc}
\hline $\begin{array}{l}\text { Fonte de } \\
\text { variação }\end{array}$ & $\begin{array}{c}\text { Soma de } \\
\text { Quadrados }\end{array}$ & gl & $\begin{array}{c}\text { Quadrado } \\
\text { Médio }\end{array}$ & F & Sig. \\
\hline Modelo & 1,940 & 2 & 0,970 & 1,564 & 0,078 \\
Intercepto & 2567,713 & 1 & 2567,713 & 4139,822 & $<0,001$ \\
Sexo & 0,010 & 1 & 0,010 & 0,017 & 0,897 \\
Faixa etária & 1,924 & 1 & 1,924 & 3,103 & $\mathbf{0 , 0 7 8}$ \\
Erro & 365,946 & 590 & 0,620 & & \\
\hline Total & 3561,389 & 593 & & & \\
\hline
\end{tabular}

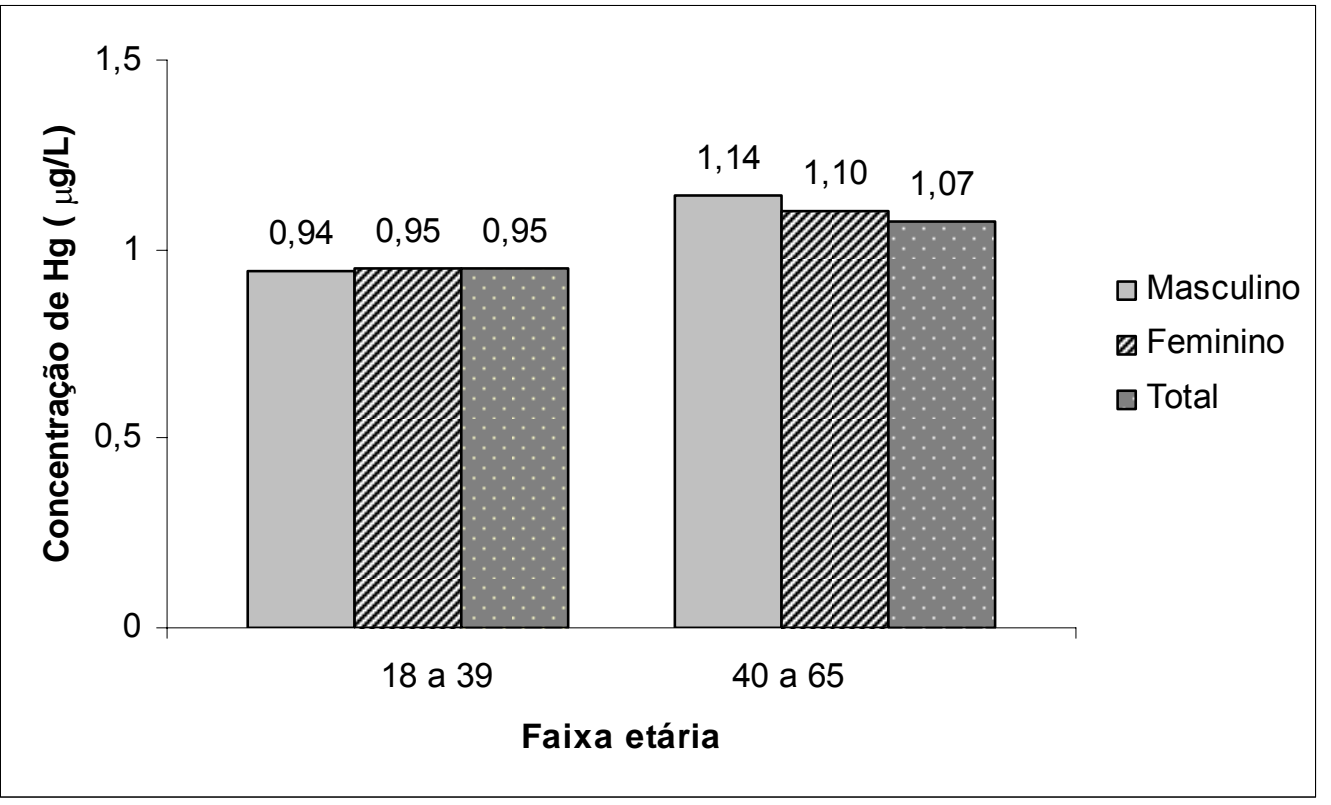

Figura 12 - Médias geométricas de mercúrio em sangue $(\mu \mathrm{g} / \mathrm{L})$ da população estudada, segundo sexo e faixa etária 
A Tabela 15 apresenta as estatísticas relativas ao ajuste do modelo linear geral para o cádmio, foram considerados todos os doadores. O resultado do ajuste do modelo mostra que há efeito significativo na interação entre o sexo e a faixa etária, isto é, nas mulheres com o aumento da idade observa-se aumento dos níveis de cádmio. Nos homens o nível médio das concentrações praticamente manteve-se nas faixas etárias. A Figura 13 apresenta de forma gráfica as médias geométricas observadas de cádmio $(\mu \mathrm{g} / \mathrm{L})$ por sexo e faixa etária.

Tabela 15 - Relacionamento das variáveis sexo e faixa etária com os níveis de cádmio no sangue

\begin{tabular}{lccccc}
\hline Fonte de variação & $\begin{array}{c}\text { Soma de } \\
\text { Quadrados }\end{array}$ & gl & $\begin{array}{c}\text { Quadrado } \\
\text { Médio }\end{array}$ & $\mathbf{F}$ & Sig. \\
\hline Modelo & 10,077 & 3 & 3,359 & 5,785 & 0,001 \\
Intercepto & 9477,941 & 1 & 9477,941 & 16323,654 & $<0,001$ \\
Sexo & 0,025 & 1 & 0,025 & 0,043 & 0,836 \\
Faixa etária & 6,594 & 1 & 6,594 & 11,356 & $\mathbf{0 , 0 0 1}$ \\
Interação SxFE & 4,173 & 1 & 4,173 & 7,188 & $\mathbf{0 , 0 0 8}$ \\
Erro & 310,635 & 535 & 0,581 & & \\
\hline Total & 12756,252 & 539 & & & \\
\hline
\end{tabular}

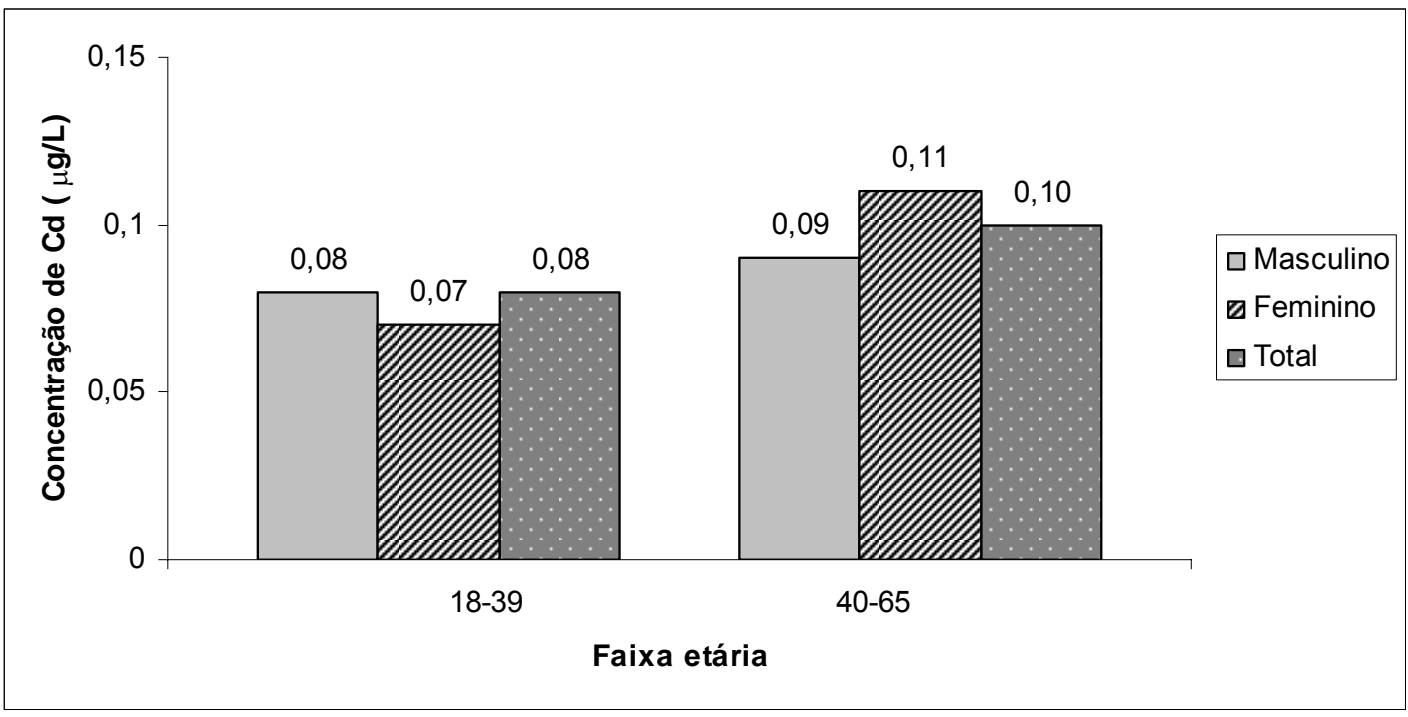

Figura 13 - Médias geométricas de cádmio $(\mu \mathrm{g} / \mathrm{L})$ segundo sexo e faixa etária 


\subsection{Valores de referência para os metais segundo sexo e faixa etária}

Para a proposição de VR optou-se pelo limite superior do IC 95\% do P95 das distribuições ajustadas dos metais. A Tabela 16 apresenta os valores relativos ao indicador selecionado para a concentração de metal em sangue. Também são apresentados os respectivos Intervalos de Confiança para a média e os valores dos percentis, obtidos a partir do ajuste de distribuições cujos parâmetros (média e desvio) foram estimados por meio da técnica de Máxima Verossimilhança.

Tabela 16 - Valores de referência para $\mathrm{Pb}, \mathrm{Cd}$ e $\mathrm{Hg}$ em sangue $(\mu \mathrm{g} / \mathrm{L})$, derivados dos valores ajustados a partir das distribuições e corrigidos no caso do cádmio

\begin{tabular}{|c|c|c|c|c|c|c|c|c|c|c|c|c|}
\hline \multirow{2}{*}{ Metal } & \multirow{2}{*}{ Sexo } & \multirow{2}{*}{$\begin{array}{l}\text { Faixa } \\
\text { etária }\end{array}$} & \multirow{2}{*}{$\mathbf{N}$} & \multirow{2}{*}{$\mathbf{M G}^{1}$} & \multicolumn{2}{|c|}{ IC $95 \%{ }^{2}$} & \multicolumn{4}{|c|}{$\begin{array}{l}\text { Percentis Máxima } \\
\text { Verossimilhança }\end{array}$} & \multicolumn{2}{|c|}{ IC $95 \%^{3}$} \\
\hline & & & & & LI & LS & P10 & P50 & P90 & P95 & LI & LS \\
\hline \multirow{4}{*}{ PB } & \multirow{2}{*}{ Masc. } & 18 a 39 & 234 & 26,46 & 25,00 & 28,00 & 15,01 & 26,46 & 46,63 & 54,76 & 50,20 & 59,73 \\
\hline & & 40 a 65 & 82 & 32,94 & 29,90 & 36,30 & 18,56 & 32,94 & 58,47 & 68,81 & 59,30 & 79,84 \\
\hline & \multirow{2}{*}{ Fem. } & 18 a 39 & 158 & 17,61 & 16,23 & 19,10 & 9,02 & 17,61 & 34,38 & 41,56 & 36,68 & 47,09 \\
\hline & & 40 a 65 & 65 & 21,26 & 18,65 & 24,24 & 10,65 & 21,26 & 42,43 & 51,61 & 42,21 & 63,10 \\
\hline \multirow{4}{*}{ Cd } & \multirow{2}{*}{ Masc. } & 18 a 39 & 234 & 0,08 & 0,08 & 0,09 & 0,03 & 0,08 & 0,23 & 0,35 & 0,30 & 0,41 \\
\hline & & 40 a 65 & 82 & 0,09 & 0,07 & 0,10 & 0,03 & 0,09 & 0,24 & 0,28 & 0,22 & 0,35 \\
\hline & \multirow{2}{*}{ Fem. } & 18 a 39 & 158 & 0,07 & 0,06 & 0,08 & 0,03 & 0,07 & 0,16 & 0,39 & 0,32 & 0,48 \\
\hline & & 40 a 65 & 65 & 0,11 & 0,09 & 0,13 & 0,04 & 0,11 & 0,33 & 0,36 & 0,29 & 0,44 \\
\hline \multirow{4}{*}{$\mathrm{Hg}$} & \multirow{2}{*}{ Masc. } & 18 a 39 & 234 & 0,94 & 0,83 & 1,06 & 0,33 & 0,94 & 2,61 & 3,57 & 2,96 & 4,30 \\
\hline & & 40 a 65 & 94 & 1,14 & 0,98 & 1,32 & 0,43 & 1,14 & 3,27 & 4,05 & 3,21 & 5,10 \\
\hline & \multirow{2}{*}{ Fem. } & 18 a 39 & 185 & 0,94 & 0,85 & 1,05 & 0,37 & 0,94 & 2,42 & 3,16 & 2,68 & 3,71 \\
\hline & & 40 a 65 & 80 & 1,10 & 0,91 & 1,33 & 0,36 & 1,10 & 3,33 & 4,56 & 3,41 & 6,10 \\
\hline $\begin{array}{l}{ }^{1} \text { Mé } \\
{ }^{3} \text { Int } \\
\text { LI: L }\end{array}$ & geo & $\begin{array}{l}\text { trica } \\
5 \% \text { d } \\
\text { or do }\end{array}$ & $\begin{array}{l}{ }^{2} \text { In } \\
\text { onfia } \\
95 \%\end{array}$ & valo & $95^{\circ}$ & e co & $\begin{array}{l}\text { ança } \\
\text { 5) }\end{array}$ & MG & & & & \\
\hline
\end{tabular}


As Tabelas 17 a 19 foram elaboradas com a finalidade de verificar a adequação da proposta de valores de referência para o $\mathrm{Cd}$, baseada na correção do P30, e para o Pb e Hg baseados em P95, como sendo o Limite Superior do IC95\% do P95, conforme Tabela 16 (anterior). Ao analisarmos as Tabelas 17 a 19, vemos que em todos os casos as porcentagens foram bastante coerentes com o indicador usado para a definição dos valores de referência.

Tabela 17 - Distribuição dos casos de concentração de Cd em sangue acima dos valores de referência (VR)

\begin{tabular}{lccc}
\hline \multirow{2}{*}{ Sexo } & \multicolumn{2}{c}{ Faixa etária } & \multirow{2}{*}{ Total } \\
\cline { 2 - 3 } & $18-39$ & $40-65$ & \\
\hline Masculino & & & 296 \\
$\mathrm{~N}$ abaixo do VR Cd & 219 & 77 & $93,7 \%$ \\
$\mathrm{~N}$ acima do VR Cd & $93,6 \%$ & $93,9 \%$ & 20 \\
& 15 & 5 & $6,3 \%$ \\
Total & $6,4 \%$ & $6,1 \%$ & 316 \\
& 234 & 82 & $100 \%$ \\
\hline Feminino & $100 \%$ & $100 \%$ & \\
$\mathrm{~N}$ abaixo do VR Cd & & & 212 \\
& 153 & 59 & $95,1 \%$ \\
$\mathrm{~N}$ acima do VR Cd & $96,8 \%$ & $90,8 \%$ & 11 \\
& 5 & 6 & $4,9 \%$ \\
Total & $3,2 \%$ & $9,2 \%$ & 223 \\
& 158 & 65 & $100 \%$ \\
\hline
\end{tabular}


Tabela 18 - Distribuição dos casos de concentração de $\mathrm{Pb}$ em sangue acima dos valores de referência

\begin{tabular}{lccc}
\hline \multirow{2}{*}{ Sexo } & \multicolumn{2}{c}{ Faixa etária } & Total \\
\cline { 2 - 3 } & $18-39$ & $40-65$ & \\
\hline Masculino & & & 301 \\
$\mathrm{~N}$ abaixo do VR Cd & 222 & 79 & $95,3 \%$ \\
& $94,9 \%$ & $96,3 \%$ & 15 \\
$\mathrm{~N}$ acima do VR Cd & 12 & 3 & $4,7 \%$ \\
& $5,1 \%$ & $3,7 \%$ & 316 \\
Total & 234 & 82 & $100 \%$ \\
& $100 \%$ & $100 \%$ & \\
Feminino & & & \\
$\mathrm{N}$ abaixo do VR Cd & 154 & 64 & 218 \\
& $97,5 \%$ & $98,5 \%$ & $97,8 \%$ \\
$\mathrm{~N}$ acima do VR Cd & 4 & 1 & 5 \\
& $2,5 \%$ & $1,5 \%$ & $2,2 \%$ \\
Total & 158 & 65 & 223 \\
& $100 \%$ & $100 \%$ & $100 \%$ \\
\hline
\end{tabular}

Tabela 19 - Distribuição dos casos de concentração de Hg em sangue acima dos valores de referência

\begin{tabular}{lccc}
\hline \multirow{2}{*}{ Sexo } & \multicolumn{2}{c}{ Faixa etária } & \multirow{2}{*}{ Total } \\
\cline { 2 - 3 } & $18-39$ & $40-65$ & \\
\cline { 2 - 3 } Masculino & & & \\
$\mathrm{N}$ abaixo do VR Cd & 228 & 93 & 321 \\
& $97,4 \%$ & $98,9 \%$ & $97,9 \%$ \\
$\mathrm{~N}$ acima do VR Cd & 6 & 1 & 7 \\
& $2,6 \%$ & $1,1 \%$ & $2,1 \%$ \\
Total & 234 & 94 & 328 \\
& $100 \%$ & $100 \%$ & $100 \%$ \\
Feminino & & & \\
$\mathrm{N}$ abaixo do VR Cd & 177 & 78 & 255 \\
& $95,7 \%$ & $97,5 \%$ & $96,2 \%$ \\
$\mathrm{~N}$ acima do VR Cd & 8 & 2 & 10 \\
& $4,3 \%$ & $2,5 \%$ & $3,8 \%$ \\
Total & 185 & 80 & 265 \\
& $100 \%$ & $100 \%$ & $100 \%$ \\
\hline
\end{tabular}




\section{DI SCUSSÃO}

\subsection{Valores de referência propostos para chumbo, cádmio e mercúrio}

Os valores de referência propostos (Tabela 16), foram estratificados para sexo e faixa etária, pois, pelo menos para o chumbo, esses fatores mostraram ser determinantes para a concentração do metal no sangue. No caso do mercúrio, a faixa etária parece ter influência nas concentrações desse metal, o que não acontece com o sexo. Dessa maneira, para o mercúrio os VR poderiam ser estratificados apenas por faixa etária. Já para o Cd, pelo ajuste do modelo linear geral, observou-se que há aumento das concentrações de $\mathrm{Cd}$ nas mulheres com o aumento da idade, esta interação não foi percebida no sexo masculino. Para manter a uniformidade, decidiuse apresentar os VR dos três metais estratificados por sexo e faixa etária, como são na maioria das vezes, apresentados os VR em outros países (Puklová, 2008; Apostoli et al., 2002; CDC, 2005a; Schulz et al., 2007b).

A opção em usar o limite superior da distribuição dos valores observados como VR, é em razão desse parâmetro ser utilizado nos estudos mais representativos de biomonitorização de população de vários países. A similaridade metodológica, inclusive na expressão dos VR, facilita a 
comparação entre os diversos estudos. Ademais, a falta de informações sobre a exposição da população geral aos metais estudados no nosso país, tanto de dados de biomonitorização como ambientais, não nos permite estabelecer os cenários de exposição a que nossa população está exposta. Dessa maneira um parâmetro mais abrangente que incluísse as possíveis variações nas concentrações dos metais devido a fatores sóciodemográficos, de estilo de vida, e de características individuais, nos pareceu mais adequado. Porém, tivemos a preocupação de apresentar os dados de maneira descritiva e detalhada, com a inclusão na Tabela 16 de outros parâmetros além do estimador usado para derivar os VR. Dessa maneira, fica disponibilizada uma fonte importante de informações para os setores interessados, os quais poderão optar por outros parâmetros que possam ser utilizados como VR, conforme seus julgamentos.

A utilização dos resultados do estudo deve ser orientada segundo o objetivo do interessado, no caso de avaliar a situação geral dessa população em relação à exposição ambiental a esses metais, a média pode fornecer essa informação. Mas em outra situação mais específica onde se suspeita de exposição aumentada de determinado grupo de indivíduos, o P95 e seu IC95\% podem ser mais indicados.

No sentido de comparar os resultados aqui encontrados com outros estudos que derivaram VR, foi elaborada a Tabela 26 , com os valores de referência para $\mathrm{Pb}, \mathrm{Cd}$ e $\mathrm{Hg}$ no sangue estimados para várias populações. É importante ressaltar que nesses estudos foram usadas diferentes metodologias para derivar os VR, bem como os parâmetros estatísticos 
adotados. Somente os dados de 2005 e 2007 da República Checa não são os VR daquela população e sim correspondem às medianas obtidas nos estudos de biomonitorização desses anos. Mesmo assim, foram colocados na tabela por serem dados atualizados que podem ser usados para comparar com nossos resultados. O estudo da República Checa coleta rotineiramente esses dados, periodicamente os avalia e compara com dos anos anteriores, e os disponibiliza às autoridades para subsidiar decisões em meio ambiente e saúde pública. A avaliação desses dados pode indicar a necessidade de atualização do VR já estabelecido anteriormente, nesse caso os novos VR serão derivados a partir desses estudos mais atuais. Do contrário, permanecem os já estabelecidos, como é o caso dos VR vigentes atualmente para a população Checa, que são aqueles derivados com base nos estudos do período de 2001-2003. 
Tabela 20 - Valores e intervalos de referência propostos para chumbo, cádmio e mercúrio em sangue de adultos ( $\mu \mathrm{g} / \mathrm{L}$ ) em diversas populações

\begin{tabular}{|c|c|c|c|c|c|}
\hline LOCAL E ANO DO ESTUDO & POPULAÇÃO & CHUMBO & CÁDMIO & MERCÚRIO & REFERÊNCIA \\
\hline $\begin{array}{l}\text { Diversos países } \\
\text { Após } 1976\end{array}$ & $\begin{array}{l}\text { Não come peixe } \\
\text { Baixo consumo peixe } \\
\text { Médio consumo peixe } \\
\text { Alto consumo peixe } \\
\text { Consumo desconhecido peixe }\end{array}$ & - & - & $\begin{array}{c}2 \pm 1,8^{a} \\
5 \pm 3,8^{a} \\
7,5 \pm 4,8^{a} \\
42,7 \pm 26,7^{a} \\
5 \pm 2,8^{a}\end{array}$ & Nordberg et al., 1992 \\
\hline $\begin{array}{l}\text { República Checa } \\
\text { 1996-1999 }\end{array}$ & $\begin{array}{l}\text { Masculino } \\
\text { Feminino } \\
\text { Total }\end{array}$ & $\begin{array}{c}95^{b} \\
80^{b} \\
-\end{array}$ & $\begin{array}{c}- \\
- \\
1,2^{b}\end{array}$ & $\begin{array}{c}- \\
- \\
2,8^{b}\end{array}$ & Kliment, 2000 \\
\hline $2001-2003$ & $\begin{array}{l}18-59 \text { anos } \\
\text { Masculino } \\
\text { Feminino } \\
\text { Total } \\
\text { Fumante } \\
\text { Não fumante }\end{array}$ & $\begin{array}{l}80^{b} \\
65^{b} \\
75^{b} \\
80^{b} \\
75^{b}\end{array}$ & $\begin{array}{l}3,5^{b} \\
3^{b} \\
3^{b} \\
4,5^{b} \\
1,1^{b}\end{array}$ & $\begin{array}{l}3,1^{b} \\
4^{b} \\
3,5^{b} \\
3,6^{b} \\
3,4^{b}\end{array}$ & Batáriová et al., 2006 \\
\hline 2005 & $\begin{array}{l}\text { Masculino } \\
\text { Feminino } \\
\text { Total } \\
\text { Fumante } \\
\text { Não fumante }\end{array}$ & $\begin{array}{l}35^{\mathrm{c}} \\
27^{\mathrm{c}} \\
- \\
- \\
-\end{array}$ & $\begin{array}{l}- \\
- \\
- \\
1,3^{c} \\
0,5^{c}\end{array}$ & $\begin{array}{l}0,91^{\mathrm{c}} \\
1,16^{\mathrm{c}} \\
- \\
- \\
-\end{array}$ & Lustigová e Puklová, 2006 \\
\hline 2007 & $\begin{array}{l}\text { Masculino } \\
\text { Feminino } \\
\text { Total } \\
\text { Fumante } \\
\text { Não fumante }\end{array}$ & $\begin{array}{l}33^{c} \\
24^{c} \\
- \\
- \\
-\end{array}$ & $\begin{array}{l}- \\
- \\
- \\
1^{c} \\
0,3^{c}\end{array}$ & $\begin{array}{l}0,8^{\mathrm{c}} \\
0,9^{\mathrm{c}} \\
- \\
- \\
-\end{array}$ & \\
\hline
\end{tabular}


Conclusão Tabela 20

\begin{tabular}{|c|c|c|c|c|c|}
\hline LOCAL E ANO DO ESTUDO & POPULAÇÃO & CHUMBO & CÁDMIO & MERCÚRIO & REFERÊNCIA \\
\hline $\begin{array}{l}\text { Alemanha } \\
1997 / 99\end{array}$ & $\begin{array}{l}\text { 18-69 anos } \\
\text { Masculino } \\
\text { Feminino } \\
\text { Total } \\
\text { Não fumante } \\
\text { Come peixe } \leq 3 x \text { mês }\end{array}$ & $\begin{array}{l}90^{d} \\
70^{d} \\
- \\
- \\
-\end{array}$ & $\begin{array}{l}- \\
- \\
1^{d} \\
-\end{array}$ & $\begin{array}{l}- \\
- \\
- \\
2^{d}\end{array}$ & $\begin{array}{l}\text { Schulz et al., 2007a; } \\
\text { Wilhelm et al., } 2004\end{array}$ \\
\hline $\begin{array}{l}\text { Brasil - Londrina (PR) } \\
\text { 1994-1996 }\end{array}$ & $\begin{array}{l}\text { Masculino } \\
\text { Feminino } \\
\text { Total }\end{array}$ & $\begin{array}{c}12-140,4^{\mathrm{e}} \\
56^{\mathrm{f}} \\
12-134,9^{\mathrm{e}} \\
54^{\mathrm{f}} \\
12-137,2^{\mathrm{e}} \\
55^{\mathrm{f}}\end{array}$ & $\begin{array}{l}- \\
- \\
-\end{array}$ & $\begin{array}{l}- \\
- \\
-\end{array}$ & Paoliello et al., 2001 \\
\hline $\begin{array}{l}\text { EUA - NHANES } \\
1999-2000\end{array}$ & $\begin{array}{l}\text { Masculino } \\
\text { Feminino } \\
\text { Total } \\
\text { Feminino/16-49 anos }\end{array}$ & $\begin{array}{c}60(54-65)^{\mathrm{g}} \\
40(37-42)^{\mathrm{g}} \\
52(48-55)^{\mathrm{g}} \\
-\end{array}$ & $\begin{array}{c}1,3(1,2-1,5)^{g} \\
1,3(1,1-1,4)^{g} \\
1,5(1,4-1,6)^{g} \\
-\end{array}$ & $\begin{array}{c}- \\
- \\
- \\
7,1(5,3-11,3)^{9}\end{array}$ & CDC, 2005a \\
\hline 2001-2002 & $\begin{array}{l}\text { Masculino } \\
\text { Feminino } \\
\text { Total } \\
\text { Feminino/16-49 anos }\end{array}$ & $\begin{array}{c}53(50-55)^{g} \\
36(30-38)^{g} \\
46(42-49)^{g} \\
-\end{array}$ & $\begin{array}{c}1,4(1,2-1,8)^{\mathrm{g}} \\
1,4(1,2-1,6)^{\mathrm{g}} \\
1,6(1,3-1,8)^{\mathrm{g}} \\
-\end{array}$ & $\begin{array}{c}- \\
- \\
- \\
4,6(3, \overline{7}-5,9)^{g}\end{array}$ & \\
\hline Itália - Brescia & $\begin{array}{l}\text { Masculino } \\
\text { Feminino }\end{array}$ & - & $\begin{array}{l}0,64 \pm 0,5^{a} \\
0,43 \pm 0,36^{a}\end{array}$ & - & Apostoli e Alessio, 1991 \\
\hline $\begin{array}{l}\text { Itália - sete áreas } \\
2000\end{array}$ & $\begin{array}{l}\text { Masculino } \\
\text { Feminino }\end{array}$ & $\begin{array}{c}45,1 \pm 27,4^{\mathrm{a}} \\
100,5^{\mathrm{h}} \\
30,6 \pm 16,7^{\mathrm{a}} \\
61^{\mathrm{h}}\end{array}$ & $\begin{array}{l}- \\
-\end{array}$ & $\begin{array}{l}- \\
-\end{array}$ & Apostoli et al., 2002 \\
\hline $\begin{array}{l}\text { Bélgica - Flandres } \\
2002-2006\end{array}$ & $50-65$ anos & $39,6(38,4-40,9)^{i}$ & $0,42(0,4-0,44)^{i}$ & - & Schroijen et al., 2008 \\
\hline
\end{tabular}

${ }^{\mathrm{a}}$ Média \pm Desvio padrão; ${ }^{\mathrm{b}}$ Valor do IC95\% do P95; ${ }^{\mathrm{C}}$ Mediana; ${ }^{\mathrm{d}}$ Limite superior do IC95\% do P95; ${ }^{\mathrm{e}}$ Média \pm 2 DP

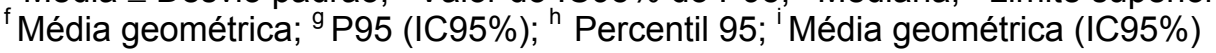




\subsubsection{Chumbo}

No Brasil, poucos estudos foram feitos tendo por escopo avaliar os níveis "background" de exposição a metais da população geral adulta. Um deles analisou amostras de sangue de uma população de referência constituída por 520 voluntários adultos entre 1994 e 1996 residentes na área urbana de Londrina (Paoliello et al., 2001). Embora os VR aqui propostos para chumbo estejam dentro dos intervalos de referência adotados no estudo de Paoliello et al. (2001) (Tabela 20), ao compararmos as médias geométricas dos 2 estudos, nota-se que as nossas são menores. O valor médio mais elevado encontrado no estudo de Londrina também pode ter sido influenciado pela inclusão de fumantes (até 10 cigarros por dia), pois alguns estudos apontam o cigarro como fonte de exposição ao $\mathrm{Pb}$. Outros estudos foram feitos com população sem exposição ocupacional ao chumbo, mas não tinham por objetivo propor VR, o de Fernícola e Azevedo (1981) e o de Nogueira et al. (1979). As médias dos grupos amostrados nesses estudos também foram acima dos VR propostos e das médias obtidas no estudo com doadores. Fernícola e Azevedo (1981) encontraram as seguintes médias em indivíduos sem exposição ocupacional ao chumbo e residentes no município de Embu-Guaçu (SP), área de escassa exposição a fontes fixas e móveis de emissão de chumbo: para homens entre 17 e 49 anos, média de $149 \mu \mathrm{g} / \mathrm{L} \pm 51$; para mulheres entre 15-32 anos, média de $72 \mu \mathrm{g} / \mathrm{L} \pm 26$; para fumantes entre 15-49 anos, média de $144 \mu \mathrm{g} / \mathrm{L} \pm 57$; para não-fumantes entre 15-42 anos, média de $85 \mu \mathrm{g} / \mathrm{L} \pm 39$. Nesse mesmo estudo, um outro grupo formado por 
moradores da cidade de São Paulo (SP), expostos fundamentalmente a fontes móveis de emissão de chumbo, apresentou as seguintes plumbemias: homens entre 16-38 anos, média de $142 \mu \mathrm{g} / \mathrm{L} \pm 43$; mulheres entre 19 e 46 anos, média de $93 \mu \mathrm{g} / \mathrm{L} \pm 39$. As médias e os VR apresentados no presente estudo também ficaram abaixo das médias do estudo de Nogueira et al. (1979) feito com voluntários sem exposição ocupacional ao chumbo residentes na Grande São Paulo, com idades entre 20 e 69 anos, cuja média para o sexo masculino foi $172 \mu \mathrm{g} / \mathrm{L} \pm 78$ e para o feminino $142 \mu \mathrm{g} / \mathrm{L} \pm 71$. Um estudo realizado em São Paulo (SP) com gestantes, no período de fevereiro de 2003 a julho de 2004, para avaliar a associação entre níveis de Pb em sangue e aborto espontâneo, não encontrou associação entre exposição ao $\mathrm{Pb}$ e abortamento. As médias encontradas foram $27,1 \mu \mathrm{g} / \mathrm{L}$ para os casos, 23,9 $\mu \mathrm{g} / \mathrm{L}$ para os controles e $22,4 \mu \mathrm{g} / \mathrm{L}$ para gestantes sem exposição ocupacional e no $3^{\circ}$ trimestre de gestação (Rosalem, 2004). A média do último grupo foi o mais próximo às médias para o sexo feminino do presente estudo.

A comparação com os estudos mencionados deve ser feita com cautela, pois vários fatores devem ser considerados, entre eles as diferenças metodológicas na seleção da população de referência, no tratamento dos dados e nos métodos de análise do chumbo utilizados nos diferentes estudos, além das diferenças geográficas e temporais que apontam para cenários de exposição diferentes nesses estudos. Os dados históricos de países que realizam há décadas biomonitorização de populações mostram uma diminuição da exposição ao chumbo ao longo dos anos, fato atribuído à retirada do chumbo da gasolina e maior controle, com conseqüente 
diminuição das emissões, de fontes industriais (Muntner et al., 2005; Lustigová e Puklová, 2006; Puklová, 2008). Essa explicação também pode ser dada às diferenças encontradas nos VR aqui relatados e naqueles valores observados nos estudos feitos no Brasil, pois quase 30 anos separam os dois primeiros estudos do presente e cerca de 10 anos daquele realizado por Paoliello et al.(2001). Nota-se que os valores encontrados no estudo mais recente (Rosalem, 2004), foram mais próximos das médias encontradas no presente estudo. Talvez essa explicação pudesse ser corroborada caso o Brasil possuísse um programa de biomonitorização da população a contaminantes ambientais.

Ao compararmos os VR aqui derivados com os de outros países (Tabela 20), percebe-se que no caso do $\mathrm{Pb}$, os VR derivados são muito semelhantes aos estabelecidos para a República Checa com base nos dados de 2001-2003. Os demais dados, de 2005 e 2007, correspondem às medianas encontradas, mas ainda não se derivou outros VR. Se compararmos as nossas médias com os dados mais atualizados da República Checa, os nossos valores são menores. Já os VR da Alemanha para população de 18 a 69 anos, mostram-se muito próximos aos aqui propostos, de cerca de $80 \mu \mathrm{g} / \mathrm{L}$ para homens e de $63 \mu \mathrm{g} / \mathrm{L}$ para mulheres de 40 a 65 anos. Porém, há de se considerar que os VR da Alemanha para adultos foram derivados com base nos dados de 1997 a 1999, e esses não foram ainda atualizados. Os VR derivados para a RMSP são menores do que os propostos por Apostoli et al. (2002) em estudo realizado em sete áreas da Itália em 2000. Mas são mais elevados do que os do NHANES (EUA) de 2001-2002, principalmente para os VR derivados para a faixa etária maior. 
Devemos fazer algumas considerações ao compararmos os nossos resultados com o de outros países. Como os fatores sexo e faixa etária se mostraram fortemente associados às concentrações dos metais em sangue, principalmente no caso do chumbo, optou-se por estratificar os VR segundo essas variáveis. No entanto, alguns países estratificam apenas por sexo, mas não por faixa etária, apresentando resultados separados somente para crianças.

Outro fator que pode estar influenciando nas diferenças observadas entre os diferentes estudos, e que já foi mencionado, é que no da RMSP não foram incluídos os fumantes. Alguns estudos encontram associação significativa entre $\mathrm{Pb}$ em sangue e fumo (Batáriová et al., 2006; Lee et al., 2005; Weyermann e Brenner, 1997; Zielhuis et al., 1978; Hernandez-Avila et al., 2000), essa associação também foi observada no nosso estudo piloto (Kuno et al., 2007), no qual foram analisadas amostras de 239 indivíduos sem exposição ocupacional ao $\mathrm{Pb}$, e a média para fumantes foi $32 \mu \mathrm{g} / \mathrm{L}$ e para os não fumantes $26 \mu \mathrm{g} / \mathrm{L}$. Por esse motivo o fumo foi um critério de exclusão para composição da amostra do estudo com doadores. Aqueles estudos que consideram separadamente esse grupo, como o da República Checa, o fazem sem separar por sexo. Portanto, há de se ponderar essas diferenças na comparação dos valores.

Os níveis de chumbo no sangue da população geral dos Estados Unidos têm diminuído nas últimas três décadas devido à legislação que restringe o uso de chumbo em tintas, em combustíveis e em materiais de encanamento reduzindo a exposição a este metal. O estudo populacional 
NHANES indicou que de 1976 a 1991, a concentração de chumbo no sangue da população norte americana (faixa etária de 1 a 74 anos) diminuiu de 128 para 28 Mg/L (redução de 78\%). A prevalência de concentrações de chumbo maiores que $100 \mu \mathrm{g} / \mathrm{L}$ também diminuiu drasticamente de $77,8 \%$ para 4,3\%. Dados da segunda fase do mesmo estudo, realizado no período de 1991 a 1994, mostraram que 4,4\% das crianças com idades entre 1 e 5 anos tinham concentração de chumbo no sangue maior que $100 \mu \mathrm{g} / \mathrm{L}$, e a média geométrica nesta faixa etária foi de $27 \mu \mathrm{g} / \mathrm{L}$. Os dados de 1999 a 2002, mostraram que somente $1,6 \%$ das crianças de 1 a 5 anos tinha concentração de chumbo no sangue maior que $100 \mu \mathrm{g} / \mathrm{L}$, com média geométrica de $19 \mu \mathrm{g} / \mathrm{L}$ (ATSDR, 2007).

Estudos populacionais realizados na Alemanha, os "German Environmental Surveys" (GerESs), demonstraram que a média geométrica da concentração de chumbo no sangue da população adulta (25 a 69 anos) teve uma redução significativa de 45,5 $\mu \mathrm{g} / \mathrm{L}$ em 1990/1992 para 31,6 $\mu \mathrm{g} / \mathrm{L}$ em 1998 (redução de 30\%). Esta diminuição foi observada tanto em mulheres (de $37,7 \mu \mathrm{g} / \mathrm{L}$ para $26,9 \mu \mathrm{g} / \mathrm{L}$ ) como em homens (de $55 \mu \mathrm{g} / \mathrm{L}$ para $37,2 \mu \mathrm{g} / \mathrm{L})$. Em crianças de 6 a 14 anos, também foi verificada a diminuição da média geométrica de chumbo no sangue de 32,3 $\mathrm{\mu g} / \mathrm{L}$ em 1990/1992 para 15,7 $\mu \mathrm{g} / \mathrm{L}$ em 2003/2006 (redução de 50\%). Novamente, este decréscimo foi atribuído ao uso de combustível sem chumbo e ao controle de emissão por indústrias durante esse período (Schulz et al, 2007b). Essa redução também foi observada em Turin, na Itália (Bono et al., 1995) e na Bélgica (Ducoffre et al, 1990). 
Apesar do decréscimo dos níveis de $\mathrm{Pb}$ em sangue evidenciado na população de Turin, na Itália, esses ainda são superiores aos da população americana. Este fato é atribuído por Bono et al. (1995) à defasagem entre os períodos históricos em que foram adotadas as restrições ao uso do $\mathrm{Pb}$. Esse também pode ser um dos motivos pelos quais os VR aqui derivados serem mais elevados do que os dos EUA. A suspensão do uso de chumbo na gasolina no Brasil foi adotada nos anos 80 , porém até hoje a gasolina utilizada em aeronaves de pequeno porte ainda contém esse metal como aditivo (Paoliello e De Capitani, 2007; Cetesb, 2008b).

Outros estudos realizados no estado de São Paulo, mas que tinham por objetivo avaliar exposição da população residente próxima a fontes de emissão de chumbo, principalmente indústrias de reprocessamento de chumbo, avaliaram as concentrações desse metal em sangue de adultos. Em Pindorama (SP), Kuno et al. (1994) observaram que a concentração de chumbo no sangue variava de acordo com a distância da fonte. Os níveis de chumbo no sangue de indivíduos que residiam próximos à fonte de emissão variaram de 48,5 $\mu \mathrm{g} / \mathrm{L}$ (2 $\mathrm{km}$ distante da fonte) a $277 \mu \mathrm{g} / \mathrm{L}$ (entre $600 \mathrm{e}$ $800 \mathrm{~m}$ distante da fonte). Em outro estudo em Jacareí (SP), as plumbemias variaram de $48 \mu \mathrm{g} / \mathrm{L}$ a $160 \mu \mathrm{g} / \mathrm{L}$ (Kuno et al., 1995). Esses estudos indicam que essas fontes fixas de poluição podem aumentar muito as concentrações de chumbo no sangue da população exposta. Portanto, precisa-se considerar ainda a contaminação ambiental em áreas que foram contaminadas no passado por atividades antrópicas e que mesmo estando as fontes atualmente controladas, deixaram um remanescente de contaminação ambiental. 
A U.S. EPA (2008) considera o chumbo como um poluente atmosférico perigoso e estabeleceu recentemente a concentração máxima de chumbo no ar de $0,15 \mu \mathrm{g} / \mathrm{m}^{3}$. Esse novo padrão é dez vezes menor que o anterior e foi revisado para melhorar a proteção da saúde de grupos de risco, especialmente crianças. A União Européia estabeleceu em 1999 o valor orientador de chumbo no ar de $0,5 \mu \mathrm{g} / \mathrm{m}^{3}$ para ser atingido em 2005 , e nas imediações de fontes industriais, a meta é $1 \mu \mathrm{g} / \mathrm{m}^{3}$ até 2010 (WHO, 2007).

No Brasil, não há padrões de qualidade estabelecidos para o chumbo no ar. No estado de São Paulo, a Cetesb, mediu em alguns pontos da RMPSP (Região Metropolitana de São Paulo) o chumbo nos anos 1993, 1997 e 2003. A Tabela 21, mostra as concentrações médias anuais de chumbo obtidas em quatro estações de monitoramento de qualidade do ar. Observa-se que os níveis médios de chumbo apresentaram redução em 1997, em relação a 1993, nas quatro estações. Já os níveis encontrados em 2003 foram praticamente os mesmos dos encontrados em 1997 (Lopes et al., 2007).

Tabela 21 - Médias anuais das concentrações de chumbo no ar em quatro estações de monitoramento da Cetesb. 1993 a 2003

\begin{tabular}{lcccc}
\hline & \multicolumn{4}{c}{ Concentrações médias anuais de chumbo $\left(\mu \mathrm{g} / \mathrm{m}^{3}\right)$} \\
\cline { 2 - 5 } & Parque D. Pedro I & Ibirapuera & S. Caetano do Sul & Osasco \\
1993 & 0,17 & 0,10 & 0,12 & 0,11 \\
1997 & 0,09 & 0,07 & 0,09 & 0,08 \\
2003 & 0,09 & 0,06 & 0,09 & 0,08 \\
\hline
\end{tabular}

FONTE: Lopes et al., 2007 
Em relação à contaminação da água subterrânea e superficial na UGHRI 6 - Alto Tietê, a Unidade de Gerenciamento de Recursos Hídricos onde está grande parte da RMSP, não apresentou concentrações preocupantes de chumbo no período de 2003 a 2007, segundo relatórios da Cetesb (Cetesb, 2004; 2006; 2007b,c; 2008a; Dias, 2008).

Em um estudo realizado pela Cetesb para avaliar a condição da qualidade dos solos da RMSP, foram encontrados valores de chumbo em amostras de solo do Parque Trianon (município de São Paulo), que corroboram com a hipótese de deposição de chumbo em decorrência de transporte aéreo. A concentração de $188 \mathrm{mg} / \mathrm{kg}$ foi encontrada na camada superficial de $0-2 \mathrm{~cm}$, enquanto a concentração da camada de 0 a $20 \mathrm{~cm}$ foi bem inferior, com $42,9 \mathrm{mg} / \mathrm{kg}$. Os autores levantam a hipótese de que as áreas onde as concentrações foram maiores, Serra da Cantareira, Serra de Paranapiacaba e espigão central da Bacia de São Paulo, por serem topograficamente mais elevadas, serviriam de obstáculo ao transporte aéreo de material particulado, favorecendo a deposição de chumbo nessas áreas (Cetesb, 2008b).

As médias encontradas no presente estudo indicam que no geral, a população estudada não está exposta a níveis preocupantes de chumbo. As análises ambientais aqui apresentadas da RMSP, também reforçam o nosso resultado. Como a principal exposição ao $\mathrm{Pb}$ ambiental se dá por meio da exposição ao solo contaminado e por ser ele um contaminante que persiste e se acumula no ambiente, é muito importante que seja monitorado, principalmente nas áreas onde pode haver passivos ambientais e acúmulo no solo. 
Gehardsson et al. (1996) analisaram mais de 1000 artigos publicados entre 1980 e 1994 que propunham VR para chumbo em sangue de adultos sem exposição ocupacional. Encontraram grande variação nos níveis de $\mathrm{Pb}$, pois esses são influenciados por numerosos fatores, como local e época da coleta de amostra. Por essa razão, concluíram não ser possível estabelecer valores de referência internacionais gerais para $\mathrm{Pb}$ em sangue.

Algumas vezes os VR são válidos para regiões geográficas pequenas, em outros casos para áreas maiores como um país. Também, as mudanças de fontes de exposição que ocorrem ao longo do tempo refletem nos resultados do biomonitorização. $\mathrm{Na}$ Suécia, a média geométrica de $\mathrm{Pb}$ em sangue de escolares diminuiu de $60 \mu \mathrm{g} / \mathrm{L}$ para $25 \mu \mathrm{g} / \mathrm{L}$ em um período de 15 anos. O uso de gasolina sem chumbo provavelmente foi o principal fator dessa queda, mas no mesmo período outros fatores também contribuíram como a eliminação do uso de chumbo em soldas de latas para acondicionamento de alimentos e do uso de cerâmicas revestidas com material contendo chumbo (Gerhardsson et al., 1996).

Na análise de regressão linear múltipla, as variáveis que tiveram associação significativa com $\mathrm{Pb}$ em sangue foram sexo e faixa etária (Tabela 11). Outros estudos também encontraram essas associações (Maranelli et al., 1990; Apostoli et al., 2002; Weyermann e Brenner, 1998; Nash et al., 2003; Bono et al., 1995). Porém o estudo realizado em Londrina por Paoliello et al. (2001) não encontrou diferença entre os sexos.

Outros fatores descritos na literatura como possíveis determinantes dos níveis de chumbo em sangue como consumo de bebida alcoólica, 
escolaridade, renda, origem da água de consumo e pressão arterial, mostraram associações estatisticamente significantes na análise univariada, mas perderam sua importância no modelo de regressão múltipla.

No caso da pressão arterial vale ressaltar que muitos estudos, encontram correlação entre concentrações de chumbo em sangue e alterações na pressão sanguínea (Apostoli et al., 1992; Navas-Acien et al., 2007). Desde os anos 1970, atenção especial tem sido dada para a possibilidade de que exposições da população geral mesmo a níveis baixos de chumbo possam elevar a pressão sanguínea em adultos e aumentar o risco para hipertensão, fator de risco para doenças cardiovasculares e mortalidade. Evidências dessa associação são encontradas nos estudos epidemiológicos, mas a natureza causal exata dessa relação ainda é controversa (Nash et al., 2003). Por esse motivo, decidiu-se incluir essa variável na análise de regressão, apesar das medidas utilizadas neste estudo não terem sido obtidas seguindo um protocolo apropriado. A pressão arterial muito alterada (pressão sistólica acima de $180 \mathrm{mmHg}$ ou abaixo de $100 \mathrm{mmHg}$, ou pressão diastólica maior que $100 \mathrm{mmHg}$ ou menor que $60 \mathrm{mmHg}$ ) é motivo de exclusão do indivíduo para doação, procedimento que faz parte dos exames de triagem da Colsan. Portanto, a nossa variável pressão alterada (PA) não incluía os casos mais graves de hipertensão.

$\mathrm{Na}$ análise univariada, a PA mostrou associação significativa $(p<0,001)$ com concentração de chumbo em sangue, porém, na análise de regressão múltipla, essa variável perdeu a significância $(p=0,098)$. 


\subsubsection{Cádmio}

Não foram encontrados na literatura estudos realizados no Brasil com proposta de VR para esse metal. Os VR derivados para o $\mathrm{Cd}$ no presente estudo (ao redor de $0,5 \mu \mathrm{g} / \mathrm{L}$ ) são claramente inferiores aos reportados em outros países. Por exemplo, na Alemanha o VR é $1 \mu \mathrm{g} / \mathrm{L}$ e nos EUA variam de 1,3 a $1,6 \mu \mathrm{g} / \mathrm{L}$. Há que se explicar que muitos estudos de biomonitorização não descartam os fumantes no cálculo de VR, e as concentrações de Cd nesses indivíduos são mais elevadas devido ao conteúdo do metal na folha de tabaco (McKelvey et al., 2007). Também na população da República Checa, a influência do hábito de fumar nos níveis desse metal tem sido repetidamente confirmada, onde os níveis de Cd em sangue de fumantes são de 2 a 3 vezes maiores do que nos não fumantes. Tem-se observado que os níveis de $\mathrm{Cd}$ no sangue de não fumantes monitorados em 2007 não diferem dos períodos anteriores (Puklová, 2008). Como no presente estudo foram excluídos doadores de sangue fumantes, os VR devem ser comparados somente com os VR reportados para não fumantes. Mesmo assim, o VR derivado e a média geral encontrada para todos os doadores, de 0,082 $\mu \mathrm{g} / \mathrm{L}$ (Tabela 8) são bem menores dos reportados em outros países, essa diferença, portanto, deve ser atribuída a diferentes níveis de exposição das populações estudadas.

Em um estudo realizado na Suécia para avaliar a exposição da população ao $\mathrm{Pb}, \mathrm{Cd}$ e Hg, esses metais foram analisados em eritrócitos da 
população nos anos de 1990, 1994 e 1999. O resultado observado foi um decréscimo de 5 a $6 \%$ por ano das concentrações de Pb e Hg. Nos níveis de Cd o decréscimo foi observado apenas em fumantes. Os autores do estudo concluíram que as medidas de controle de poluição aliadas à diminuição do uso de amálgamas dentárias foram responsáveis pela redução da exposição ao $\mathrm{Pb}$ e $\mathrm{Hg}$, e que a exposição ao $\mathrm{Cd}$ pelo tabaco diminuiu, mas que não houve mudanças significativas das outras fontes ambientais do Cd (Wennberg et al., 2006).

Por outro lado, alguns estudos têm demonstrado uma diminuição dos níveis de cádmio no sangue da população na Europa e em outras áreas. Na Bélgica, em estudo feito com um grupo de homens expostos a cádmio por fontes não ocupacionais e que foram examinados anualmente entre 1984 e 1988, a média da concentração de cádmio no sangue diminuiu de 2,25 $\mu \mathrm{g} / \mathrm{L}$ para $0,79 \mu \mathrm{g} / \mathrm{L}$ (decréscimo anual de 14\%) (WHO, 2007). No Japão, entre 1980 e 1990, também houve um declínio da média geométrica de cádmio no sangue, de $3,8 \mu \mathrm{g} / \mathrm{L}$ para $1,79 \mu \mathrm{g} / \mathrm{L}$ em homens e de 3,57 $\mu \mathrm{g} / \mathrm{L}$ para 1,84 $\mu \mathrm{g} / \mathrm{L}$ em mulheres (Watanabe et al., 1993).

Já os estudos populacionais na Alemanha, German Environmental Surveys (GerES), demonstraram que a média geométrica de cádmio no sangue da população adulta (25 a 69 anos) teve um aumento significativo de 0,37 $\mu \mathrm{g} / \mathrm{L}$ em 1990/1992 para 0,43 $\mu \mathrm{g} / \mathrm{L}$ em 1998. E na população de nãofumantes houve um aumento de $0,23 \mu \mathrm{g} / \mathrm{L}$ para $0,28 \mu \mathrm{g} / \mathrm{L}$, sugerindo que houve um aumento na concentração de cádmio nos alimentos e no ambiente (Schulz et al, 2007b). 
As diferenças encontradas nas tendências temporais dos níveis de Cd em sangue das diversas populações, excluindo-se a exposição pelo tabaco, devem ser atribuídas às principais fontes de exposição a esse metal na população geral de não fumantes, que são os alimentos e o ambiente.

Na RMSP, os dados sobre níveis de $\mathrm{Cd}$ no ambiente, estão disponíveis para água superficial e subterrânea, e solo. As concentrações encontradas nesses meios, mostram níveis baixos desse metal. No período de 2001 a 2006, na RMSP, mais de 90\% das amostras de água tanto superficial como subterrânea estiveram abaixo do limite de quantificação do método (Cetesb, 2004; 2006; 2007b,c).

No estudo realizado pela Cetesb para avaliar a qualidade dos solos da RMSP, em 2004 e 2005, as concentrações em áreas agrícolas variaram de $<0,10$ a $1,40 \mathrm{mg} / \mathrm{kg}$ e em fragmentos de mata de $<0,10$ a $0,11 \mathrm{mg} / \mathrm{kg}$ (Cetesb, 2008b).

Na literatura, há referências sobre a influência dos procedimentos analíticos na variação dos dados de biomonitorização (Schulz et al., 2007b; Nordberg, 1996). Os cuidados para evitar contaminação no momento da coleta e análise da amostra são cruciais para obtenção de resultados confiáveis (Sabbioni et al., 1992). Nos últimos anos, o conhecimento da importância desse fato levou a uma melhora significativa das condições de coleta e análise de amostras, com a utilização de material livre de contaminação por esse metal e a utilização de ambiente adequado ("sala limpa") para realizar os procedimentos analíticos (Nordberg, 1996). Uma outra explicação para a variabilidade dos dados, é a diferença nos 
limites de quantificação dos métodos utilizados nos diversos estudos. Batáriová et al. (2006) também consideram a influência desse fato sobre o valor mais elevado da mediana encontrado no sangue de não fumantes da população Checa em relação à Alemã. O LQ do método utilizado pela Alemanha é 0,12 $\mu \mathrm{g} / \mathrm{L}$, e o do estudo da República Checa é 0,20 $\mu \mathrm{g} / \mathrm{L}$. No presente estudo o $L Q$ foi de $0,1 \mu \mathrm{g} / \mathrm{L}$, muito próximo ao da Alemanha. De fato, o LQ influencia nos resultados, pois os valores que se situam abaixo do LQ são em geral, computados na análise estatística como metade do LQ, e por conseqüência, quanto maior for a quantidade de dados nessa situação e maior for o valor do LQ, mais superestimado será o resultado final. Somado a isso, uma outra razão para os VR aqui derivados serem menores, pode estar relacionado ao método estatístico usado para derivar o VR de Cd para a RMSP, que foi a partir do ajuste da distribuição dos valores que ficaram acima do LQ. A vantagem desse recurso estatístico é que ele utiliza os valores observados na população estudada, o que torna a inferência mais próxima da realidade e não sujeita à sensibilidade do método analítico.

Mesmo sendo baixo o LQ do método usado no presente estudo, muitos valores de $\mathrm{Cd}$ em sangue foram inferiores a ele. Porém, analisandose os resultados de biomonitoração de populações nos diversos países, o LQ do presente estudo é um dos mais baixos, o que mostra que o método analítico utilizado tem sensibilidade adequada para a tecnologia disponível. Para que essa limitação, muitos valores abaixo do LQ, não prejudicasse a derivação de um VR para Cd, utilizou-se de recurso estatístico para obter um VR que fosse realmente representativo dos dados obtidos. A Tabela 17 
mostra que esse recurso atendeu o objetivo, pois a distribuição dos casos de concentração de Cd em sangue observados acima dos valores de referência (VR) foram 6,3\% do total para homens e 4,9\% para mulheres. Assim, a metodologia estatística utilizada para derivar os VR para Cd poderia ser aplicada em outros estudos, quando grande parte dos valores observados estiver abaixo do LQ, fato tão freqüentemente observado.

\subsubsection{Mercúrio}

Também para o Hg não foram encontrados estudos que derivaram VR desse metal em sangue para população brasileira. As médias de $\mathrm{Hg}$ em sangue encontradas no presente estudo mostraram-se abaixo dos valores limites estabelecidos com base em efeitos à saúde. A comparação dos VR aqui derivados para $\mathrm{Hg}$ com os de outros países, mostra que esses são próximos aos reportados no NHANES (EUA) e superiores ao da Alemanha (2 $\mathrm{\mu g} / \mathrm{L})$ e da República Checa. Dados mais recentes mostram que as medianas de mercúrio em sangue da população adulta Checa nos últimos anos (2005 e 2007), mostram-se muito próximas aos das medianas encontradas para os doadores da RMSP. Porém, os P95 da população Checa para o anos de 2005 não ultrapassaram 4 g/L e para 2007 ficaram abaixo de $3 \mu \mathrm{g} / \mathrm{L}$ (Puklová, 2008). Chamamos atenção a esse fato, pois o VR (limite superior do IC95\% do P95) para mercúrio derivado no presente estudo tanto para homens como para mulheres, 5,1 $\mu \mathrm{g} / \mathrm{L}$ e $6,1 \mu \mathrm{g} / \mathrm{L}$, respectivamente, para a faixa etária de 40-65 anos, estão acima do valor 
limite para adultos estabelecido pela Alemanha (HBM I) de $5 \mu \mathrm{g} / \mathrm{L}$. Entretanto, apenas $1,3 \%$ (8 casos) dos nossos resultados ficaram acima dessa concentração, no último estudo da República Checa somente 0,7\% (2 casos) excedeu esse valor (Puklová, 2008). Esse limite foi estabelecido com base nos dados para mulheres em idade reprodutiva, mas também é recomendado para outros grupos (Schulz et al., 2007b). O HBM I indica o limite abaixo do qual não é esperado efeito adverso à saúde na população geral. Quando as concentrações estão entre o HBM I e HBM II, não se pode excluir o aparecimento de efeito, e é recomendável verificar os resultados analíticos, investigar possíveis fontes, que devem ser eliminadas (Schulz et al., 2007b). Diante dos VR derivados, as autoridades de saúde devem avaliar a possibilidade de derivar VR para as populações mais suscetíveis como gestantes, mulheres em idade fértil e crianças, e também considerar a alternativa de estabelecer VR de Hg para populações de diferentes padrões de consumo de pescado. Essas estratificações podem ser úteis para adoção de medidas de restrição de consumo de determinados tipos de alimentos.

O consumo de pescado é uma das principais fontes de exposição ao mercúrio. Por essa razão, alguns países apresentam os VR de Hg para subgrupos da população, em função do consumo de peixe. Por exemplo, a Alemanha derivou o VR de $\mathrm{Hg}$ em sangue considerando uma população que consome peixe até 3 vezes no mês. No nosso estudo, pela análise de regressão múltipla, verificou-se também que a freqüência de consumo de pescado influencia sobremaneira as concentrações de $\mathrm{Hg}$ em sangue. McKelvey et al. (2007) analisaram concentrações de metais em sangue de uma 
amostra representativa de 1811 residentes na cidade de Nova York que participaram do NHANES 2004. Nesse estudo encontraram os seguintes valores de P95 para mercúrio em sangue: 10,70 $\mathrm{gg} / \mathrm{L}$ e 11,31 $\mathrm{\mu g} / \mathrm{L}$ para homens e mulheres respectivamente. Para indivíduos que fizeram até 9 refeições com pescado nos últimos 30 dias, o P95 (IC95\%) foi 9,34 $\mu \mathrm{g} / \mathrm{L}$ $(7,96-10,27)$ e para os que não consomem foi $5,39 \mu \mathrm{g} / \mathrm{L}(4.40-7,16)$. Valores esses que estão acima daqueles observados para a população americana. Comparando-se esses valores com os propostos para a RMSP, os últimos são próximos aos reportados para pessoas que não consomem peixe no estudo de Nova York, o que é coerente, pois apesar de não termos derivado VR por consumo de pescado, a maioria dos doadores de sangue estudada come pouco peixe, isto é, reportou que não consome ou consome uma vez por mês. Mas ao compararmos os VR aqui derivados com os da Alemanha, os nossos são bem superiores, uma das explicações pode ser o conteúdo mais elevado de $\mathrm{Hg}$ nos peixes consumidos aqui, mas este fato requer mais investigação.

O consumo de pescado foi a variável mais fortemente associada ao aumento dos níveis de $\mathrm{Hg}$ em sangue, fato corroborado em outros estudos (McKelvey et al., 2007; Gundacker et al., 2006; Oskarsson et al.,1996), os doadores que comem diariamente ou mais de uma vez na semana, apresentam níveis mais de $100 \%$ superior àqueles que não comem peixe. E mesmo tendo sido o grupo estudado formado por indivíduos que consomem pouco peixe, pode-se perceber pelos coeficientes estimados, um gradiente de contribuição das diferentes freqüências de consumo para a variável dependente. 
Além do consumo de peixe, os fatores que mais se relacionaram às concentrações de $\mathrm{Hg}$ no sangue foram escolaridade, presença de restauração de amálgama e faixa etária (Tabela 12). Não encontramos associação entre Hg e sexo, mas na República Checa (Puklová, 2008) as mulheres apresentam níveis mais altos e também encontraram uma diferença significativa entre os níveis de $\mathrm{Hg}$ em sangue de pessoas que não comem peixe e os que regularmente o fazem.

A influência da escolaridade pode estar relacionada ao hábito de comer peixe, uma vez que as pessoas com maior nível de escolaridade tiveram concentrações mais elevadas de $\mathrm{Hg}$ em sangue. No estudo de Nova York (McKelvey et al., 2007), as pessoas com maior renda apresentaram níveis mais elevados de mercúrio, fato atribuído pelos autores, ao consumo por esses indivíduos, de peixes mais caros que são os do topo da cadeia alimentar, e que consequentemente apresentam níveis maiores de $\mathrm{Hg}$. Pode ser que esse fato também tenha interferido nos nossos resultados, mas renda não foi determinante para $\mathrm{Hg}$ em sangue. Porém temos que considerar que isso pode ser devido ao $\mathrm{n}$ muito pequeno de doadores com renda mais alta (Tabela 6). Gundacker et al. (2006) em estudo realizado na Áustria com doadores de sangue também encontrou que os homens de menor nível de escolaridade tinham níveis mais baixos de $\mathrm{Hg}$ em sangue e atribuiu isso ao fato de indivíduos com maior escolaridade consumir mais pescado, pois encontrou correlação positiva entre consumo de frutos do mar e nível de educação.

A presença de restauração de amálgama também mostrou associação com os níveis de $\mathrm{Hg}$, fato também encontrado em outros 
estudos. Na Suécia, um estudo realizado com mulheres, encontrou correlação significativa entre concentrações de $\mathrm{Hg}$ total e inorgânico em sangue e leite materno, com o número de restaurações de amálgama (Oskarsson et al., 1996). Os estudos de biomonitorização muitas vezes relacionam os níveis de $\mathrm{Hg}$ com o número de restaurações de amálgama. Devido à dificuldade em se obter essa informação nos Postos de Coleta da Colsan, pelo tempo reduzido de contato com o doador, optou-se por perguntar apenas se o indivíduo possuía ou não restaurações de amálgama. O $\mathrm{Hg}$ presente nas restaurações dentárias é uma fonte importante de contaminação. Existem estudos que mostram a diminuição do $\mathrm{Hg}$ em sangue quando da substituição das restaurações por outras com material isento de $\mathrm{Hg}$ (Gundacker et al., 2006).

Quanto à faixa etária, esta variável mostrou associação positiva para $\mathrm{Hg}$ em sangue, indivíduos da maior faixa etária tem quase $20 \%$ mais $\mathrm{Hg}$ quando comparados aos da menor faixa. Contrariamente, no estudo da Áustria, os homens da faixa mais alta de idade, entre 51 e 65 anos, apresentaram níveis mais baixos de $\mathrm{Hg}$. Esse fato não foi observado em mulheres. Os autores sugerem que haja uma diferença no padrão de consumo de pescado nas diferentes idades (Gundacker et al., 2006).

As informações sobre dados ambientais na região mostram que em relação à qualidade de água tanto superficial como subterrânea, os níveis encontrados para o Hg são muito baixos (Cetesb, 2004; 2007b,c; 2008; Dias, 2008). As concentrações de mercúrio em solos para a RMSP foram mais elevadas do que as obtidas para o Estado, porém os níveis foram considerados 
baixos. As concentrações para a RMSP variaram de <0,01 a 0,22 mg/kg em área agrícola e de $<0,01$ a 0,28 mg/kg para fragmentos de mata. Para o estado de São Paulo variaram de <0,02 a 0,08 mg/kg (Cetesb, 2008b).

Considerando as médias das concentrações de Hg no sangue obtidas dos doadores e os dados ambientais disponíveis, aparentemente, a RMSP não tem níveis de $\mathrm{Hg}$ elevados. No entanto, o consumo de pescado e a presença de amálgama dentária, devem ser as principais vias de exposição ao Hg da população estudada. O uso de restaurações com amálgama está diminuindo nos últimos anos, assim o controle do conteúdo de $\mathrm{Hg}$ no pescado deve ser priorizado já que alguns indivíduos tiveram concentrações acima do valor limite de $5 \mu \mathrm{g} / \mathrm{L}$.

\subsection{Utilização de doadores de sangue para derivação de VR e a representatividade da amostra}

Em razão da dificuldade em se obter amostras de sangue de indivíduos saudáveis não ocupacionalmente expostos aos metais chumbo, cádmio e mercúrio em uma amostragem aleatória da população, o presente estudo foi realizado com doadores de sangue. Tendo em vista essa limitação, deve-se ter claro que os VR aqui derivados não foram obtidos de uma amostra representativa da população da RMSP, mas foram oriundos de uma amostra de indivíduos adequadamente selecionados com vistas à obtenção de níveis de $\mathrm{Pb}, \mathrm{Cd}$ e $\mathrm{Hg}$ em sangue 
que excluíssem exposições ocupacionais ou ambientais anômalas. A proposta é que os VR derivados sejam utilizados como orientadores para avaliar exposições de populações urbanas com as mesmas características do grupo estudado.

Por outro lado, apesar de os doadores de sangue ser um grupo diferenciado da população quanto ao estado de saúde, sendo no geral mais saudáveis, diversos estudos utilizam esse grupo como representativos da população adulta para estabelecer valores de referência (Hrnčířová et al., 2008). Ducoffre et al. (1990), fizeram uma revisão sobre os níveis de chumbo em sangue na Bélgica desde 1978, na qual citam um estudo que mostrou não haver diferença significativa nos níveis de chumbo em sangue de um grupo selecionado aleatoriamente da população e de um grupo de doadores de sangue. Outros países (Apostoli e Alessio, 1991; Braga, 1992; Duca, 1992; Batáriová et al., 2006) utilizam também doadores de sangue como representativos da população geral para estabelecer valores referência. A República Checa realiza rotineiramente, desde 1994, o biomonitoramento da população para avaliar a exposição a contaminantes ambientais, utilizando doadores de sangue com idades entre 18-58 anos (ČERNÁ et al., 2007).

Como já discutido no item 2.1.2, o problema em selecionar indivíduos de referência saudáveis reside na dificuldade em se definir saúde. Gräsbeck (1990), contrariamente à definição de saúde da OMS, que considera utópica, "estado de completo bem-estar físico, mental e social e não somente a ausência de doença", defende que saúde é um 
estado relativo e subjetivo e que depende do objetivo de quem usa o termo. Assim, saúde é um conceito orientado pelo objetivo, mais do que um "estado" mencionado na definição da OMS. Na derivação de valores de referência, a definição de saúde depende da intenção do uso dos VR (PetitClerc e Solberg, 1987).

Isso posto, podemos dizer que os VR aqui derivados representam os níveis "background" dos metais em sangue de doadores de sangue dos 9 postos da Colsan estudados, e que podem ser utilizados para comparar resultados de biomonitoração de populações com as mesmas características, isto é, indivíduos que moram em áreas urbanas, com grande densidade demográfica e atividade industrial.

A maioria do grupo estudado reside no município de São Paulo, seguido de São Bernardo do Campo e Santo André, apesar do maior número de amostras ter sido obtido nos postos de Santo André. Também mesmo tendo sido coletadas apenas 71 amostras em São Bernardo, 116 doadores residiam nesse município. Esses fatos demonstram que os doadores não necessariamente procuram os postos mais próximos da sua residência para fazer as doações. Uma explicação pode ser pelo fato de que o maior contingente de doadores foram aqueles de postos localizados dentro de hospitais. Assim o número de doações dirigidas era maior, isto é, a doação era feita para conhecidos ou parentes dos doadores. Outra explicação pode ser a proximidade do posto ao local de trabalho, porém essa informação, o endereço do trabalho, não foi obtida no estudo. 
As estimativas de número necessário de doadores por posto feitas com base no número de bolsas coletadas, não foram atendidas nos postos Ermelino Matarazzo, Tide Setúbal e Ipiranga. Como os dois primeiros estão localizados na mesma região, extremo da Região Leste do município de São Paulo, isso prejudicou a representatividade dos doadores daquela área. Mas o posto Tatuapé, também da Região Leste, teve um número de amostras, 71, superior ao estimado de 61, assim pode-se dizer que doadores da região leste foram representados na amostragem (Figura 5). O mesmo pode ser inferido para o posto Ipiranga, que está localizado na mesma região do Vergueiro, neste último foram coletadas 96 amostras enquanto que o estimado foi 75 (Tabelas 1 e 2).

\subsection{Controle de qualidade analítica e limite de quantificação do método de determinação de contaminantes ambientais}

Para a implantação de programas de biomonitorização para estabelecer VR de contaminantes ambientais em amostras biológicas humanas, é necessário seguir protocolos rigorosos de padronização de procedimentos na seleção da população de referência, para avaliar os fatores pré-analíticos (amostragem) e de controle de qualidade analítica (Gerhardsson et al., 1996). Os VR representam os níveis "background" de exposição, por isso é importante dispor de método analítico com limites de quantificação adequados que possibilite avaliar a exposição mesmo a níveis 
baixos. O objetivo da biomonitorização é prevenir exposições excessivas aos contaminantes. O conhecimento das relações dose-efeito, por exemplo, no caso do $\mathrm{Pb}$, mostram que níveis cada vez mais baixos desse metal no sangue já causam algum efeito deletério à saúde. Assim, a determinação precoce de exposições aumentadas da população geral é crucial na prevenção e promoção da saúde. Por essa razão métodos analíticos cada vez mais sensíveis terão que ser utilizados em estudos de VR. O LQ do método deve estar bem abaixo das menores concentrações que devem ser determinadas

Além dos cuidados na amostragem para evitar contaminação, a descrição do método analítico utilizado é importante para a interpretação dos resultados. A garantia da qualidade analítica refere-se a todas as etapas para assegurar a confiabilidade dos dados, e inclui a coleta, transporte e armazenamento das amostras, as análises laboratoriais, e a compilação, relato e interpretação dos resultados. A utilização de procedimentos de controle de qualidade interno e externo usando materiais de referência certificados, e as comparações interlaboratoriais permitem manter os erros em níveis aceitáveis. Também a qualidade dos resultados analíticos depende da precisão e exatidão do método empregado (Gerhardsson et al., 1996). Ao aplicar VR deve-se considerar uma incerteza analítica de $\pm 20 \%$ (Wilhelm et al., 2006). 


\section{CONCLUSÕES E RECOMENDAÇÕES}

- As médias encontradas no presente estudo indicam que, no geral, a população estudada não está exposta a níveis preocupantes de exposição ao chumbo, cádmio e mercúrio;

- As concentrações de chumbo e cádmio em sangue mostraram associação significativa com sexo e faixa etária. Para mercúrio em sangue, os fatores determinantes foram consumo de pescado, escolaridade, possuir restauração de amálgama e faixa etária;

- Devido às diferenças individuais e ambientais, os VR aqui propostos para $\mathrm{Pb}, \mathrm{Cd}$ e $\mathrm{Hg}$ devem ser utilizados na comparação com dados observados em populações adultas de características semelhantes e de áreas urbanas;

- Deve-se repetir a análise quando são encontradas concentrações acima dos VR. Uma vez confirmadas, deve-se iniciar uma investigação para identificar a fonte;

- Os VR são derivados estatisticamente e não representam limites de exposição baseados em razões toxicológicas. Assim, não podem ser usados para avaliação de saúde. Os VR devem ser usados para avaliar a exposição de indivíduos ou grupos da população comparados com exposição "background"; 
- A utilização de doadores de sangue, como grupo representativo da população para derivar VR para biomarcadores de exposição a contaminantes ambientais, mostrou que em termos logísticos e éticos é uma alternativa para a realização de estudos de biomonitorização humana em locais onde não há estudos populacionais desse porte. Devido à qualidade e quantidade de informações que podem ser obtidas desse grupo, principalmente para países como o nosso que não dispõe de recursos financeiros para realizar grandes inquéritos populacionais, o setor saúde, em seus vários níveis, deveria considerar a possibilidade de fazer coletas e avaliações sistemáticas das informações oriundas desse grupo da população;

- Devido a grande suscetibilidade de crianças e mulheres em idade fértil aos efeitos dos metais estudados, recomenda-se que outros estudos sejam realizados para propor VR para esses subgrupos da população;

- Os estudos de biomonitorização e a proposição de VR devem ser realizados de modo contínuo de maneira a possibilitar a obtenção de dados históricos para avaliar tendências e ter disponíveis VR atualizados para a correta estimativa da exposição. A expressão de resultados nos estudos de derivação de VR deve ser padronizada, conforme protocolos específicos, para que possam ser comparados com os de outras populações; e 
- O cuidado na seleção da população estudada, nos procedimentos analíticos adotados e no tratamento estatístico para derivação dos valores, e em razão da falta de VR para populações não expostas ocupacionalmente a esses metais para a nossa população, acreditamos que os VR propostos possam ser de grande valia nas avaliações de risco utilizadas tanto na área de saúde como de meio ambiente. 
8 ANEXOS 


\title{
Anexo I
}

\section{Artigo publicado}

\section{Available online at www.sciencedirect.com \\ ScienceDirect}

\section{Talanta}

Talanta 75 (2008) 246-252

\section{Biomonitoring method for the simultaneous determination of cadmium and lead in whole blood by electrothermal atomic absorption spectrometry for assessment of environmental exposure}

\author{
Fábio Kummrow ${ }^{\mathrm{a}, \mathrm{b}}$, Fábio F. Silva ${ }^{\mathrm{a}, \mathrm{c}}$, Rúbia Kuno ${ }^{\mathrm{a}, \mathrm{d}}$, \\ Alexandre L. Souza ${ }^{\mathrm{c}}$, Pedro V. Oliveira ${ }^{\mathrm{c}, *}$ \\ a Cia de Tecnologia de Saneamento Ambiental-CETESB, 05459-900 São Paulo, SP, Brazil \\ b Departamento de Análises Clínicas e Toxicológicas, Universidade Federal de Alfenas, 37130-000 Alfenas, MG, Brazil \\ ${ }^{\mathrm{c}}$ Instituto de Química, Universidade de São Paulo, 05513-970, C.P. 26077 São Paulo, SP, Brazil \\ ${ }^{\mathrm{I}}$ Faculdade de Medicina, Universidade de São Paulo, 01246-903 São Paulo, SP, Brazil \\ Received 19 July 2007; received in revised form 3 November 2007; accepted 6 November 2007 \\ Available online 13 November 2007
}

\begin{abstract}
The aim of this work is to propose a biomonitoring method for the simultaneous determination of $\mathrm{Cd}$ and $\mathrm{Pb}$ in whole blood by simultaneous electrothermal atomic absorption spectrometry for assessment of environmental levels. A volume of $200 \mu \mathrm{L}$ of whole blood was diluted in $500 \mu \mathrm{L}$ of $0.2 \%\left(\mathrm{w} \mathrm{v}^{-1}\right)$ Triton ${ }^{\otimes} \mathrm{X}-100+2.0 \%\left(\mathrm{v} \mathrm{v}^{-1}\right) \mathrm{HNO}_{3}$. Trichloroacetic acid was added for protein precipitation and the supernatant analyzed. A mixture of $250 \mu \mathrm{g} \mathrm{W}+200 \mu \mathrm{g} \mathrm{Rh}$ as permanent and $2.0 \%\left(\mathrm{w} \mathrm{v}^{-1}\right) \mathrm{NH}_{4} \mathrm{H}_{2} \mathrm{PO}_{4}$ as co-injected modifiers were used. Characteristic masses and limits of detections $(n=20,3 \mathrm{~s})$ for $\mathrm{Cd}$ and $\mathrm{Pb}$ were 1.26 and $33 \mathrm{pg}$ and $0.026 \mu \mathrm{g} \mathrm{L}^{-1}$ and $0.65 \mu \mathrm{g} \mathrm{L}^{-1}$, respectively. Repeatability ranged from 1.8 to $6.8 \%$ for $\mathrm{Cd}$ and 1.2 to $1.7 \%$ for $\mathrm{Pb}$. The trueness of method was checked by the analysis of three Reference Materials: Lyphocheck ${ }^{\oplus}$ Whole Blood Metals Control level 1 and Seronorm ${ }^{\mathrm{TM}}$ Trace Elements in Whole Blood levels 1 and 2 . The found concentrations presented no statistical differences at the $95 \%$ confidence level. Blood samples from 40 volunteers without occupational exposure were analyzed and the concentrations ranged from 0.13 to $0.71 \mu \mathrm{g} \mathrm{L}^{-1}\left(0.32 \pm 0.19 \mu \mathrm{g} \mathrm{L}^{-1}\right)$ for $\mathrm{Cd}$ and 9.3 to $56.7 \mu \mathrm{g} \mathrm{L}^{-1}\left(25.1 \pm 10.8 \mu \mathrm{g} \mathrm{L}^{-1}\right)$ for $\mathrm{Pb}$.
\end{abstract}

(1) 2007 Elsevier B.V. All rights reserved.

Keywords: Atomic absorption spectrometry; Simultaneous determination; Biomonitoring; Blood; Cadmium; Lead

\section{Introduction}

Lead and cadmium are considered two of the most toxic elements for living organisms [1-6]. The environmental persistence of these metals in concert with their intensive use by modern society has, over the years, created a concentration in the biosphere, and continuous exposure to low levels of cadmium and lead may result in bioaccumulation and health effects, by both occupational and environmental exposition [7,8].

Human biomonitoring is a useful tool in environmental medicine to assess and evaluate the background levels of internal dose of environmental pollutants in general population, population groups and individuals through measurements of those

\footnotetext{
* Corresponding author. Tel.: +55 113091 8516; fax: +55 1138155579.

E-mail address: pvolivei@iq.usp.br (P.V. Oliveira)
}

chemicals, or their metabolites in human specimens, such as blood and urine [9].

Normal exposure levels of cadmium may be small [10,11], and the improvement of working conditions and the actions taken to minimize the environment exposure to lead, such as the phase-out of leaded gasoline and improvements in food preparations and packaging, have led to a substantial reduction of the blood lead levels in general population [12-15]. Although environment quality has improved, during the last decades in many countries air levels of cadmium and lead in the vicinity of certain industrial sources, frequently located closely to residential areas, are still increased and health concerns were raised [16-19].

The determination of lead and cadmium in biological materials poses several problems mainly due to the low concentrations of these metals, the great variation of the matrix from sample to sample and contamination. Among the instrumental techniques available, electrothermal atomic absorption spectrometry 
(ETAAS) is still one of the most widely used for trace element determination in biological samples [20-22]. Particularly, ETAAS is a well-established technique for cadmium [19,23-27] and lead [19,23-25,27-29] determination in whole blood.

The availability of simultaneous atomic absorption spectrometry (SIMAAS) allowed the development of methods for the determination of two or more elements, improving the analytical frequency, reducing the cost related to instrument maintenance, sample and high purity reagents. The determinations of cadmium and lead by SIMAAS have been proposed in the literature for many types of samples including serum, urine and whole blood [30-34]. Otherwise, detection and quantification limits of these methods are not enough sensible for assessing environmental levels of these elements, mainly cadmium in whole blood of population who has low levels of internal doses. The objective of this work is to propose a high sensible method aiming the simultaneous determination of low levels of cadmium and lead in whole blood for environmental exposure assessment. The proposed method can be used in population surveys including those to determine reference values in biomonitoring programs.

\section{Experimental}

\subsection{Instrumentation}

All measurements were performed with an electrothermal atomic absorption spectrometer, SIMAAS-6000 (PerkinElmer Life and Analytical Sciences, Shelton, CT, USA), equipped with longitudinal Zeeman-effect background correction, Echelle optical arrangement and solid-state detector. End-capped transversal heating graphite tubes (EC-THGA) with integrated pyrolytically coated platforms were used throughout in this work. All solutions were delivered into the graphite tube by means an AS-72 autosampler (PerkinElmer Life and Analytical Sciences). Argon $99.996 \%$ ( $\mathrm{v} \mathrm{v}^{-1}$ ) (White Martins, São Paulo, SP, Brazil) was used as the purge gas. The instrumental setting up conditions is shown in Table 1.

After proteins precipitation, the solid phase was separated from the solution using a centrifuge (Quimis ${ }^{\circledR}$, São Paulo, SP, Brazil).

Table 1

Instrumental setting for the simultaneous determination of $\mathrm{Cd}$ and $\mathrm{Pb}$ in blood by SIMAAS- 6000

\begin{tabular}{lll}
\hline Element & $\mathrm{Pb}$ & $\mathrm{Cd}$ \\
\hline Wavelength $(\mathrm{nm})$ & 283.3 & 228.8 \\
Band pass $(\mathrm{nm})$ & 0.7 & 0.7 \\
Lamp type & $\mathrm{EDL}^{\circ}$ & $\mathrm{EDL}$ \\
Lamp current $(\mathrm{mA})$ & 450 & 230 \\
Calibration range $\left(\mu \mathrm{g} \mathrm{L}^{-1}\right)$ & $2.5-20$ & $0.1-0.8$ \\
Signal measurements & Peak area (AA-BG) & \\
Calibration equation & Linear & \\
Read time $(\mathrm{s})$ & 5.0 & \\
Standard and sample volume $(\mu \mathrm{L})$ & 12 & \\
Modifier volume $(\mu \mathrm{L})$ & 5 & \\
Standard and sample replicates & 3 & \\
\hline
\end{tabular}

EDL: Electrodeless discharge lamp.

\subsection{Reagents}

All reagents were of analytical-reagent grade unless otherwise specified. Ultra pure water with a final resistivity of $18.2 \mathrm{M} \Omega \mathrm{cm}^{-1}$ was provided by a Milli-Q water purification system (Millipore, Bedford, MA, USA). Analytical grade $\mathrm{HNO}_{3}$ $65 \%\left(\mathrm{~m} \mathrm{v}^{-1}\right)$ (Merck, Darmstadt, Germany) and Triton ${ }^{\circledR} \mathrm{X}$ 100 (Fisher Scientific, NJ, USA) was used to prepare diluent solutions. Tricloroacetic acid (TCA) (Merck) was used to precipitate proteins of whole blood. The analytical reference solutions were prepared by successive dilution of $1000 \mathrm{mg} \mathrm{L}^{-1}$ of $\mathrm{Cd}$ $\left(\mathrm{Cd}\left(\mathrm{NO}_{3}\right)_{2}\right.$ in $\left.\mathrm{H}_{2} \mathrm{O}\right)$ and $\mathrm{Pb}\left(\mathrm{Pb}\left(\mathrm{NO}_{3}\right)_{2}\right.$ in $\left.\mathrm{H}_{2} \mathrm{O}\right)$ from Titrisol ${ }^{(3)}$ standard solutions (Merck).

The permanent chemical modifier was thermally obtained from high purity $\mathrm{Na}_{2} \mathrm{WO}_{4} \cdot 2 \mathrm{H}_{2} \mathrm{O}$ (Merck) and $\mathrm{RhCl}_{3}$ (Sigma, St. Louis, MO, USA). A solution of $2 \%\left(\mathrm{~m} \mathrm{v}^{-1}\right) \mathrm{NH}_{4} \mathrm{H}_{2} \mathrm{PO}_{4}$ (Merck) was used as co-injected chemical modifier. All solutions were stored in decontaminated polyethylene bottles at room temperature.

\subsection{Sample}

Lyphocheck $^{\circledR}$ Whole Blood Metals Control level 1 (Bio-Rad, Irvine, USA) and Seronorm ${ }^{\mathrm{TM}}$ Trace Elements in Whole Blood level 1 (Lot OK0336) and level 2 (Lot MR9067) from Sero AS (Billingstad, Norway) reference materials were used to check the reliability of the entire proposed method. These lyophilized materials were reconstituted with $2 \mathrm{~mL}$ of ultrapure water.

Whole blood samples provided from 40 adult volunteers ( $>18$ years old) from São Paulo State Environment Agency (CETESB, São Paulo, SP, Brazil) were analyzed. The samples were collected in heparinized Vaccuntainer tubes and stored at $-22^{\circ} \mathrm{C}$ for about 1 week prior to the simultaneous $\mathrm{Cd}$ and $\mathrm{Pb}$ determinations.

\subsection{Procedure}

All glassware and Eppendorf ${ }^{(1)}$ (Brinkmann Instruments, Westbury, NY, USA) tubes were cleaned with detergent solution, soaked in $10 \%\left(\mathrm{v} \mathrm{v}^{-1}\right) \mathrm{HNO}_{3}$ for $24 \mathrm{~h}$, rinsed with ultra pure water, dryed and stored in a closed polypropylene container. All solution and sample manipulations were conducted in a laminar flow bench (Class II, Pachane) to avoid airborne contamination.

A solution containing $0.2 \mu \mathrm{g} \mathrm{L}^{-1} \mathrm{Cd}(\mathrm{II})$ and $5 \mu \mathrm{g} \mathrm{L}^{-1} \mathrm{~Pb}(\mathrm{II})$ in $0.1 \%\left(w^{-1}\right)$ Triton ${ }^{\circledR} \mathrm{X}-100+1.0 \%\left(\mathrm{vv}^{-1}\right) \mathrm{HNO}_{3}+6 \%$ $\left(\mathrm{wv}^{-1}\right)$ TCA was used to optimize the heating program. The pyrolysis and atomization temperatures were also optimized in presence of diluted blood solution. Pyrolysis and atomization temperature curves were simultaneously obtained for $\mathrm{Cd}$ and $\mathrm{Pb}$ in absence and presence of co-injected $2.0 \%$ $\left(\mathrm{w} \mathrm{v}^{-1}\right) \mathrm{NH}_{4} \mathrm{H}_{2} \mathrm{PO}_{4}$. The permanent chemical modifier $(250 \mu \mathrm{g}$ $\mathrm{W}+200 \mu \mathrm{g} \mathrm{Rh})$ was used in all experiments. The permanent chemical modifier was thermally deposited following the literature recommendations [35]. The pyrolysis holding time was studied considering the background absorbance intensity in presence of the diluted blood solution. 
The analytical calibration solutions were prepared in the range of $0.10-0.80 \mu \mathrm{g} \mathrm{L}^{-1}$ for $\mathrm{Cd}$ and $2.5-20 \mu \mathrm{g} \mathrm{L}^{-1}$ for $\mathrm{Pb}$ in $0.1 \%\left(\mathrm{w} \mathrm{v}^{-1}\right)$ Triton ${ }^{\otimes} \mathrm{X}-100+1.0 \%\left(\mathrm{vv}^{-1}\right) \mathrm{HNO}_{3}+6 \%$ $\left(\mathrm{w} \mathrm{v}^{-1}\right)$ TCA.

Samples and reference materials were prepared by diluting $200 \mu \mathrm{L}$ of whole blood with $500 \mu \mathrm{L}$ of diluent $0.2 \%$ $\left(\mathrm{w} \mathrm{v}^{-1}\right)$ Triton ${ }^{\otimes} \mathrm{X}-100+2.0 \%\left(\mathrm{v} \mathrm{v}^{-1}\right) \mathrm{HNO}_{3}$ in Eppendorf ${ }^{\otimes}$ (Brinkmann Instruments, Westbury, NY, USA) tubes with $1.5 \mathrm{~mL}$. All diluted blood samples were pumping with the micropipette several times to ensure that the pipet was completely rinsed and to allow homogenization. The blood solution was kept in a laminar flow bench during $60 \mathrm{~min}$ for complete red blood cells lysing. Afterwards, $300 \mu \mathrm{L}$ of $20 \%\left(\mathrm{w} \mathrm{v}^{-1}\right)$ TCA solution was added to the blood solution for proteins precipitation. Subsequently, Eppendorf ${ }^{\circledR}$ tube was manually agitated before centrifugation during $5 \mathrm{~min}$ at $7000 \mathrm{rpm}$ to enhance the separation. A volume of approximately $600 \mu \mathrm{L}$ of supernatant was transferred to the autosampler cup $(1.2 \mathrm{~mL})$ for analyze. A $12 \mu \mathrm{L}$ aliquot of reference or sample solutions and $5 \mu \mathrm{L}$ of $2.0 \%$ $\left(\mathrm{m} \mathrm{v}^{-1}\right) \mathrm{NH}_{4} \mathrm{H}_{2} \mathrm{PO}_{4}$ solution were deposited onto the integrated platform. The rinse solution was $0.1 \%\left(\mathrm{w} \mathrm{v} \mathrm{v}^{-1}\right)$ Triton ${ }^{\circledR} \mathrm{X}-100$ to perform the probe cleaning and resulting better standard deviation between the sampling. All measurements were made with at least three replicates and based on integrated absorbance.

To evaluate occlusion or co-precipitation of $\mathrm{Cd}$ and $\mathrm{Pb}$ in the precipitate a mass of approximately $50 \mathrm{mg}$ of Seronorm ${ }^{\mathrm{TM}}$ Trave Elements level 2 dry precipitate were transferred to microwave vessel with a diluted oxidant mixture $\left(1 \mathrm{~mL} \mathrm{HNO}_{3}+2 \mathrm{~mL}\right.$ $\mathrm{H}_{2} \mathrm{O}_{2}+3 \mathrm{~mL} \mathrm{H}_{2} \mathrm{O}$ ) for digestion in a closed vessel microwave oven (Microwave 3000, Anton Paar, Austria), using the following heating program (temperature, ${ }^{\circ} \mathrm{C}$; ramp, min; hold, min): $(140,5,1),(180,8,2)$ and $(220,4,10)$. Cadmium and $\mathrm{Pb}$ were determined in the resulted solution by SIMAAS.

\section{Results and discussions}

\subsection{Heating program optimization}

Based on previous results for the simultaneous determination of $\mathrm{Cd}$ and $\mathrm{Pb}$ in whole blood by SIMAAS [33], the mixture $250 \mu \mathrm{g} \mathrm{W}+200 \mu \mathrm{g} \mathrm{Rh}$ was initially elected as the permanent chemical modifier. In aqueous solution, the best pyrolysis temperatures were 400 and $500^{\circ} \mathrm{C}$ for $\mathrm{Cd}$ and $\mathrm{Pb}$, respectively, while atomization temperatures were $1700^{\circ} \mathrm{C}$ for both elements (Fig. 1). For diluted blood sample $(1+4)$, after proteins precipitation, the pyrolysis temperatures were 300 and $350^{\circ} \mathrm{C}$ for $\mathrm{Cd}$ and Pd, respectively (Fig. 2).

Pyrolysis and atomization temperatures must be selected based on the most and least volatile analyte to be simultaneously determined. The most suitable temperatures for $\mathrm{Cd}$ and $\mathrm{Pb}$ determination, using $\mathrm{W}+\mathrm{Rh}$ as chemical modifier, were 300 and $1700^{\circ} \mathrm{C}$ for pyrolysis and atomization steps, respectively.

The spectrometer calibration was performed by using aqueous analytical reference solutions ranging from 0.10 to $0.80 \mu \mathrm{g} \mathrm{L}^{-1}$ for $\mathrm{Cd}$ and 2.5 to $20 \mu \mathrm{g} \mathrm{L}^{-1}$ for $\mathrm{Pb}$ in $0.1 \%\left(\mathrm{w} \mathrm{v}^{-1}\right)$ Triton ${ }^{\circledast} \mathrm{X}-100+1.0 \%\left(\mathrm{vv}^{-1}\right) \mathrm{HNO}_{3}+6 \%\left(\mathrm{w} \mathrm{v}^{-1}\right)$ TCA. The same concentrations of matrix matched analytical reference

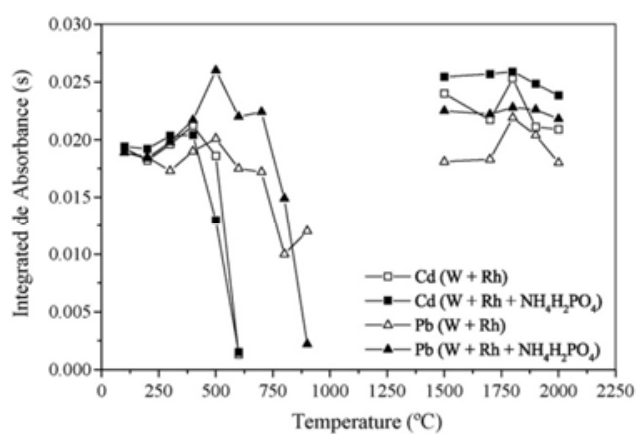

Fig. 1. Pyrolysis and atomization curves for $0.2 \mu \mathrm{g} \mathrm{L}^{-1} \mathrm{Cd}$ and $5.0 \mu \mathrm{g} \mathrm{L} \mathrm{L}^{-1} \mathrm{~Pb}$ in $0.1 \%\left(\mathbf{w ~ v}^{-1}\right)$ Triton $^{\otimes} \mathrm{X}-100+1.0 \%\left(\mathrm{v} \mathrm{v}^{-1}\right) \mathrm{HNO}_{3}+6 \%\left(\mathrm{w} \mathrm{v}^{-1}\right) \mathrm{TCA}$ with two different chemical modifier: $250 \mu \mathrm{g} \mathrm{W}+200 \mu \mathrm{g} \mathrm{Rh}$ and $250 \mu \mathrm{g} \mathrm{W}+200 \mu \mathrm{g}$ $\mathrm{Rh}+$ co-injected $2.0 \%\left(\mathrm{w} \mathrm{v}^{-1}\right) \mathrm{NH}_{4} \mathrm{H}_{2} \mathrm{PO}_{4}$

solutions were also used for spectrometer calibration to check the influence of matrix concomitants on the $\mathrm{Cd}$ and $\mathrm{Pb}$ atomization. The analytical curves for $\mathrm{Cd}$ and $\mathrm{Pb}$ in aqueous solution and diluted blood sample are shown in Figs. 3 and 4, respectively. The comparison of the slopes $(b)$ observed for calibration graphs obtained from aqueous solution with those in presence of diluted blood can be use to estimate the effect caused by the matrix. In absence of matrix effect, the ratio between the slopes obtained from aqueous solutions and diluted blood must be, approximately, 1 , and this condition ensures the adequacy of using aqueous reference solution for instrument calibration [34]. This experiment showed more pronounced matrix effects over Cd $(0.03568 / 0.02668=1.3)$ than $\mathrm{Pb}(0.00129 / 0.00133=0.97)$ atomization. This was confirmed when the reference materials were analyzed. Recoveries based on the recommended values ranged from 76 to $89 \%$ for $\mathrm{Cd}$ and 89 to $96 \%$ for $\mathrm{Pb}$.

Due to the low boiling point $\left(199^{\circ} \mathrm{C}\right) \mathrm{TCA}$ was probably removed during the drying step [36]. Consequently, the reduction in $\mathrm{Cd}$ and $\mathrm{Pb}$ thermal stability might be caused by the presence of residual organic and inorganic components of $1+4$ diluted blood. As reported in the literature, permanent chemical

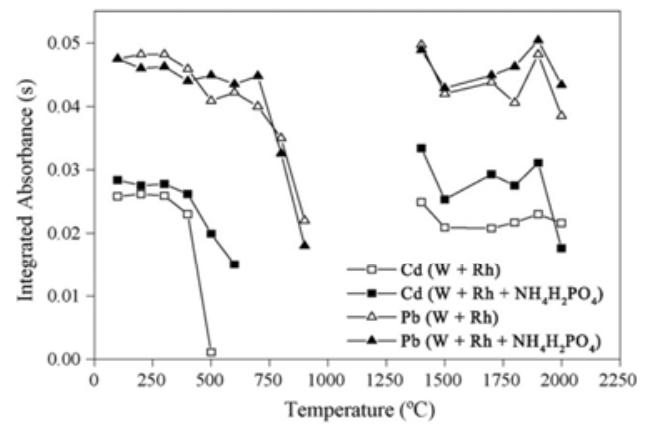

Fig. 2. Pyrolysis and atomization curves for blood $(1+4)$ diluted after protein precipitation with two different chemical modifier: $250 \mu \mathrm{g} \mathrm{W}+200 \mu \mathrm{g} \mathrm{Rh}$ and $250 \mu \mathrm{g} \mathrm{W}+200 \mu \mathrm{g} \mathrm{Rh}+$ co-injected $2.0 \%\left(\mathrm{w} \mathrm{v}^{-1}\right) \mathrm{NH}_{4} \mathrm{H}_{2} \mathrm{PO}_{4}$. 


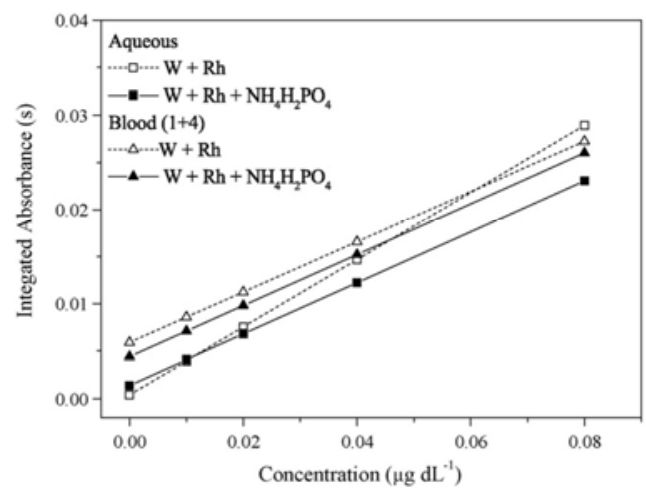

Fig. 3. Analytical curves for $\mathrm{Cd}$ in aqueous and blood sample $(1+4)$ using $250 \mu \mathrm{g} \mathrm{W}+200 \mu \mathrm{g} \mathrm{Rh}$ and $250 \mu \mathrm{g} \mathrm{W}+200 \mu \mathrm{g} \mathrm{Rh}+$ co-injected $2.0 \%\left(\mathrm{w} \mathrm{v}^{-1}\right)$ $\mathrm{NH}_{4} \mathrm{H}_{2} \mathrm{PO}_{4}$ as chemical modifiers: $(\square)$ abs. $=0.35688 \times+0.0004, r=0.99961$; (घ) abs. $=0.27058 \times+0.0014, \quad r=0.99812 ;(\Delta)$ abs. $=0.26682 \times+0.0059$, $r=0.99447 ;(\mathbf{\Lambda})$ abs $=0.27028 \times+0.0044, r=0.99929$.

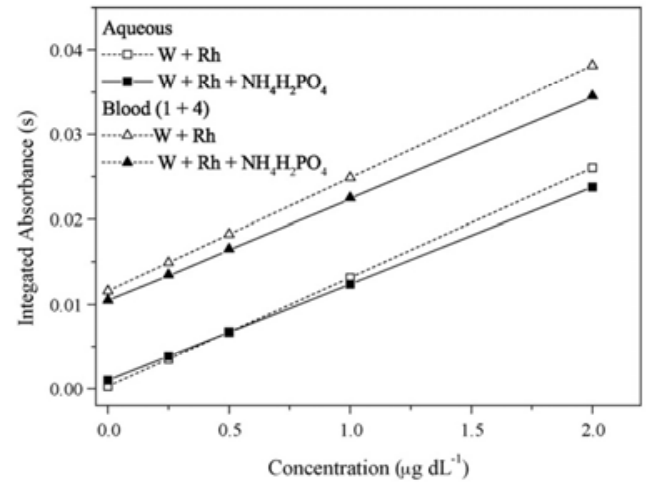

Fig. 4. Analytical curves for $\mathrm{Pb}$ in aqueous and blood sample $(1+4)$ using $250 \mu \mathrm{g} \mathrm{W}+200 \mu \mathrm{g} \mathrm{Rh}$ and $250 \mu \mathrm{g} \mathrm{W}+200 \mu \mathrm{g} \mathrm{Rh}+$ co-injected $2.0 \%\left(\mathrm{w} \mathrm{v}^{-1}\right)$ $\mathrm{NH}_{4} \mathrm{H}_{2} \mathrm{PO}_{4}$ as chemical modifiers: $(\square)$ abs $=0.01286 \times+0.0003, r=0.99806$; (घ) abs. $=0.01138 \times+0.0010, \quad r=0.99812 ;(\Delta)$ abs. $=0.01327 \times+0.0116$, $r=0.99976 ;(\Lambda)$ abs. $=0.01202 \times+0.0105, r=0.99949$.

modifier has always led to lower pyrolysis temperature when undigested biological materials are directly analyzed [37]. The high concentration of concomitants in the solution might be restrained the interaction between $\mathrm{Cd}$ and $\mathrm{Pb}$ with the permanent chemical modifier. Thus, the analyte was more susceptible to combine with any matrix concomitants, such as chloride ions. The conventional co-injection of a chemical modifier in solution form with the sample seemed to be more successful.

Taking into account the good results obtained for $\mathrm{Pb}$, we decided to combine the permanent chemical modifier $(\mathrm{W}+\mathrm{Rh})$ with the co-injected $\mathrm{NH}_{4} \mathrm{H}_{2} \mathrm{PO}_{4}$ solution.

The thermal behavior of $\mathrm{Pb}$ and $\mathrm{Cd}$ was again evaluated in presence of $2.0 \%\left(\mathrm{~m} \mathrm{v}^{-1}\right) \mathrm{NH}_{4} \mathrm{H}_{2} \mathrm{PO}_{4}$ co-injected with analytical solutions over $\mathrm{W}-\mathrm{Rh}$ permanent chemical modifier. In this condition, $\mathrm{Cd}$ and $\mathrm{Pb}$ pyrolysis temperatures were 400 and $700{ }^{\circ} \mathrm{C}$ for aqueous reference solution (Fig. 1) and 400 and $700{ }^{\circ} \mathrm{C}$ for diluted sample (Fig. 2), respectively. The atomization temperatures were 1800 and $1900^{\circ} \mathrm{C}$ for aqueous and diluted blood sample, respectively. For the combined modifiers, the presence of concomitants practically did not affect the pyrolysis temperatures. Considering the compromised conditions, pyrolysis and atomization temperatures for $\mathrm{Cd}$ and $\mathrm{Pb}$ were 400 and $1900{ }^{\circ} \mathrm{C}$, respectively. The atomization temperature was established by considering the relationship between peak area and standard deviation of three replicates for the elements.

The spectrometer was again calibrated using analytical reference solutions in aqueous and matrix matched solutions to check the performance of the combined chemical modifier. The regression coefficients $(r)$ obtained from aqueous solution and diluted blood solutions were very close to those obtained without the coinjected chemical modifier (Figs. 3 and 4). However, the slopes (b) observed for calibration graphs obtained from aqueous and in presence of diluted blood solutions were much better than those obtained in absence of co-injected modifier. The ratio between the slopes obtained from aqueous and diluted blood solutions for $\mathrm{Cd}(0.02706 / 0.02703=1.0)$ and $\mathrm{Pb}(0.00114 / 0.00120=0.95)$ showed reduction of the matrix effects, allowing instrument calibration with aqueous reference solutions.

Pyrolysis holding time was also optimized and $20 \mathrm{~s}$ was sufficient to ensure effectiveness of background correction. Peak shapes and background absorption were also considered when choosing the furnace conditions. Typical atomization peak for $\mathrm{Cd}$ and $\mathrm{Pb}$ are shown in Fig. 5. The heating program described in Table 2 was used for the determination of $\mathrm{Cd}$ and $\mathrm{Pb}$ in whole blood samples.

\subsection{Analytical characteristics of method}

Methods for simultaneous determination of $\mathrm{Cd}$ and $\mathrm{Pb}$ in whole blood have been successfully proposed using TGHA [23-29] and SIMAAS [30-34]. In many cases, whole blood was diluted $1+9$ and directly introduced into the graphite tube for

Table 2

Transversal heating graphite atomizer program (end-capped tube with integrated platform) for the simultaneous determination of $\mathrm{Cd}$ and $\mathrm{Pb}$ in blood

\begin{tabular}{lccccc}
\hline Step & Temperature $\left({ }^{\circ} \mathrm{C}\right)$ & Ramp $(\mathrm{s})$ & Hold $(\mathrm{s})$ & Ar gas flow $\left(\mathrm{mL} \mathrm{min}^{-1}\right)$ & Read \\
\hline Drying & 130 & 10 & 5 & 250 & 250 \\
Pyrolysis I & 200 & 5 & 5 & 250 & Yes \\
Pyrolysis II & 400 & 10 & 20 & - & 250 \\
Atomization & 1900 & 0 & 3 & 4 & \\
Cleaning & 2100 & 1 & 0 & \\
\hline
\end{tabular}

Injection temperature: $100{ }^{\circ} \mathrm{C}$; pipette speed: $50 \%$. 

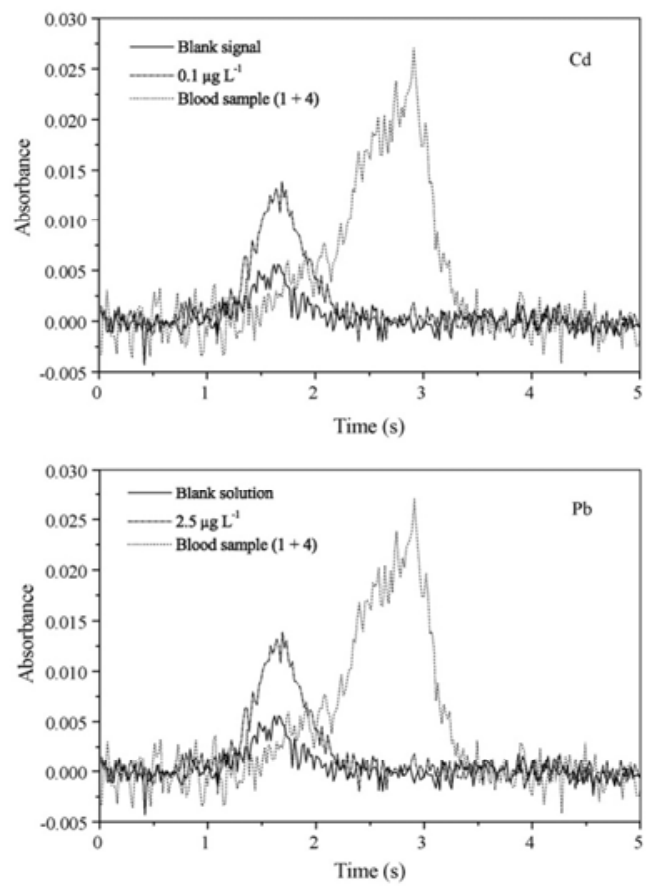

Fig. 5. Analytical signals for $\mathrm{Cd}$ and $\mathrm{Pb}$ in aqueous and blood sample $(1+4)$ using $250 \mu \mathrm{g} \mathrm{W}+200 \mu \mathrm{g} \mathrm{Rh}+$ co-injected $2.0 \%\left(\mathrm{w} \mathrm{v}^{-1}\right) \mathrm{NH}_{4} \mathrm{H}_{2} \mathrm{PO}_{4}$ as chemical modifiers.

analysis and screening purposes. However, for the assessment of background levels of these elements, high sensible methods are imperative. The use of EC-THGA graphite tube is one instrumental alternative to improve the sensitivity of SIMAAS [26]. It was observed a decrease of 13 and $20 \%$ for the $\mathrm{Cd}$ and $\mathrm{Pb}$ detection limits for end-capped in comparison to the standard graphite tubes, respectively.

But, even using this strategy we certified the necessity to improve the detectability of method to achieve background levels. The alternative was reduced the dilution of blood sample. However, when aliquots of blood solutions diluted $1+4$ were directly injected in the graphite tube, random absorbance and high background signals were observed for $\mathrm{Cd}$ and $\mathrm{Pb}$. This can be due to high concentration of organic concomitants in the final diluted whole blood. Based on previous work [38], one alternative to diminish organic concomitants in $1+4$ blood dilution was the protein precipitation with TCA. Concentrations of 5, 10, 15 and $20 \%\left(\mathrm{v} \mathrm{v}^{-1}\right)$ TCA were tested. The best TCA concentration to improve the quantitative precipitation of proteins was $20 \%$ $\left(\mathrm{v} \mathrm{v}^{-1}\right)$. After precipitation, solutions were manually agitated before centrifugation for $5 \mathrm{~min}$.

The determination of $\mathrm{Cd}$ and $\mathrm{Pb}$ in the precipitate showed concentrations below of the detection limits which attested there was not occlusion or co-precipitation of these elements.
It was essential to introduce Triton ${ }^{(} \mathrm{X}-100$ prior to the TCA solution to promote complete lysis of the cells before protein precipitation. In previous investigation $(1+9$ dilution $)$, negative errors were observed when Triton ${ }^{\circledR} \mathrm{X}-100$ and TCA were simultaneously introduced [38]. But in this work, probably because of the low blood dilution it was necessary to wait more time to promote complete lysis of red cells. Different times (0, 20, 40 and $60 \mathrm{~min}$ ) were studied and $60 \mathrm{~min}$ showed the better recoveries for $\mathrm{Cd}$ and $\mathrm{Pb}$ when reference materials were analyzed. This step can be implemented during the spectrometer calibration avoiding analytical frequency damage.

The characteristics masses were calculated from the calibration curves and based on the integrated absorbance. The detection limits (DL) were calculated considering the variability of 20 consecutive measurements of $0.1 \%\left(\mathrm{w} \mathrm{v}^{-1}\right)$ Triton $\mathrm{X}-100+1.0 \%\left(\mathrm{vv}^{-1}\right) \mathrm{HNO}_{3}+6 \%\left(\mathrm{wv}^{-1}\right)$ TCA as the blank solution $(0.0066 \pm 0.0028$ for $\mathrm{Cd}$ and $0.0057 \pm 0.0026$ for $\mathrm{Pb}$, $n=20)$, according to $3 s_{\mathrm{blk}} / b$ ( $s_{\mathrm{blk}}=$ standard deviation of the blank and $b=$ calibration curve slope). Taking into account a $1+4$ dilution factor, detection limits for the sample concentration would be $0.13 \mu \mathrm{g} \mathrm{L}^{-1}$ for $\mathrm{Cd}$ and $3.25 \mu \mathrm{g} \mathrm{L}^{-1}$ for $\mathrm{Pb}$. The characteristic masses and detection limits obtained in this work and in others methods for $\mathrm{Cd}$ and $\mathrm{Pb}$ determination in whole blood by SIMAAS are shown in Table 3 .

The performance of the EC-THGA was evaluated by comparing the slopes of calibration graphs in different lifetime of the graphite tube ( 0 up to 1060 heating cycles). The slopes $(s)$ observed for Cd $(0.03783 \pm 0.003644$, R.S.D. $=9.6 \%)$ and $\mathrm{Pb}(0.00155 \pm 0.00021$, R.S.D. $=13.5 \%)$ indicated acceptable performance, even after 1060 heating cycles. The relative standard deviations were based on the slopes obtained by using a new EC-THGA. Up to 846 heating cycles the relative standard deviations of slopes were below $10 \%$ for both elements. More than 846 heating cycles, the EC-THGA graphite tube was worn down. Consequently, we recommend working with the same EC-THGA graphite tube up to, approximately, 850 heating cycles. As related in previous work [35] and attested in this work, the improvement in the graphite lifetime can be credited to the permanent chemical modifier $(250 \mu \mathrm{g} \mathrm{W}+200 \mu \mathrm{g}$ $\mathrm{Rh})$.

Considering the simultaneous determination of $\mathrm{Cd}$ and $\mathrm{Pb}$, it was possible to have up to 1700 analytical results with the

Table 3

Characteristic masses and detection limits of $\mathrm{Cd}$ and $\mathrm{Pb}$ in whole blood for different methods by SIMAAS

\begin{tabular}{lcll}
\hline Element & $m_{\mathrm{o}}(\mathrm{pg})$ & $\mathrm{DL}\left(\mu \mathrm{g} \mathrm{L}^{-1}\right)$ & Reference \\
\hline $\mathrm{Cd}$ & 1.26 & 0.026 & This work \\
$\mathrm{Pb}$ & 33 & 0.65 & End-capped tube \\
$\mathrm{Cd}$ & - & 0.24 & 31 \\
$\mathrm{~Pb}$ & - & 1.06 & - \\
$\mathrm{Cd}$ & 1.6 & 0.03 & 33 \\
$\mathrm{~Pb}$ & 35 & 0.8 & THGA tube \\
$\mathrm{Cd}$ & 1.68 & 0.095 & 34 \\
$\mathrm{~Pb}$ & 30.3 & 0.86 & THGA tube \\
\hline
\end{tabular}


Table 4

Results for the simultaneous determination of $\mathrm{Cd}$ and $\mathrm{Pb}$ in reference materials $(n=3)$

\begin{tabular}{|c|c|c|c|c|}
\hline \multirow[t]{2}{*}{ CRM } & \multicolumn{2}{|c|}{ Found value \pm uncertainty } & \multicolumn{2}{|c|}{ Recommended values } \\
\hline & $\overline{C d}\left(\mu \mathrm{gL}^{-1}\right)$ & $\mathrm{Pb}\left(\mu \mathrm{gL}^{-1}\right)$ & $\overline{\mathrm{Cd}\left(\mu \mathrm{g} \mathrm{L}^{-1}\right)}$ & $\mathrm{Pb}\left(\mu \mathrm{gL}^{-1}\right)$ \\
\hline I & 3.7 & & $-4.5)$ & $83(6$ \\
\hline II & $0.9 \pm 0.2$ & $36 \pm 2$ & 0.7 & 33 \\
\hline III & $6.6 \pm 0.1$ & $442 \pm 5$ & $6.2(5.4-7.2)$ & $401(353-443)$ \\
\hline
\end{tabular}

I, Liphochek Bio-Rad level 1; II, Seronorm ${ }^{\mathrm{TM}}$ level 1 and III, Seronorm ${ }^{\mathrm{TM}}$ leve

same atomizer, lowering costs associated with the replacement of graphite parts.

\subsection{Cadmium and lead determination}

The spectrometer was calibrated using aqueous reference solutions ranging from 0.10 to $0.8 \mu \mathrm{g} \mathrm{L}^{-1}$ for $\mathrm{Cd}$ and from 2.5 to $20 \mu \mathrm{g} \mathrm{L}^{-1}$ for $\mathrm{Pb}$ in $0.1 \%\left(\mathrm{w} \mathrm{v}^{-1}\right)$ Triton ${ }^{\circledR} \mathrm{X}-100+1.0 \%$ $\left(\mathrm{v} \mathrm{v}^{-1}\right) \mathrm{HNO}_{3}+6 \%\left(\mathrm{w} \mathrm{v}^{-1}\right)$ TCA using instrumental conditions and the heating program listed in Tables 1 and 2, respectively. The analytical curves are depicted in Figs. 3 and 4.

The trueness of the proposed method was checked by analysis of three certified reference materials (Lyphocheck ${ }^{\circledR}$ Whole Blood Metals Control level 1 and Seronorm ${ }^{\mathrm{TM}}$ Trace Elements in Whole Blood levels 1 and 2. Results are presented in Table 4. The found $\mathrm{Cd}$ and $\mathrm{Pb}$ concentrations for the reference materials are in accordance to the acceptable range at $95 \%$ of the confidence level (Student's $t$-test).

Cadmium and $\mathrm{Pb}$ concentrations in whole blood of 40 volunteers from environmental exposure are shown in Table 5. Four blood samples were spiked with $0.1 \mu \mathrm{g} \mathrm{L}^{-1}$ of $\mathrm{Cd}$ and $2.5 \mu \mathrm{g} \mathrm{L}^{-1}$ of $\mathrm{Pb}$. Good recoveries were obtained, ranging from 98 to $115 \%$ for $\mathrm{Cd}$ and 99 to $112 \%$ for $\mathrm{Pb}$, corroborating to the use of co-injected $\mathrm{NH}_{4} \mathrm{H}_{2} \mathrm{PO}_{4}$ as chemical modifier for minimization of interferences caused by matrix constituents.

Analysis of whole blood of 40 environmental exposure volunteers ranged from 0.13 to $0.71 \mu \mathrm{g} \mathrm{L}^{-1}\left(0.32 \pm 0.19 \mu \mathrm{g} \mathrm{L}^{-1}\right)$ for $\mathrm{Cd}$ and 9.3 to $56.7 \mu \mathrm{g} \mathrm{L}^{-1}\left(25.1 \pm 10.8 \mu \mathrm{g} \mathrm{L}^{-1}\right)$ for $\mathrm{Pb}$.

The relative standard deviations between sampling $(n=3)$ ranged from 2.0 to $21 \%$ for $\mathrm{Cd}$ and 1.5 to $13 \%$ for $\mathrm{Pb}$. The repeatability (within-run precision) of method was assessed by analysis of CRMs (Lyphocheck ${ }^{\text {(i) }}$ Whole Blood Metals Control level 1 and Seronorm ${ }^{\mathrm{TM}}$ Trace Elements in Whole Blood level

Table 5

Analysis and recoveries test for the simultaneous determination of $\mathrm{Cd}$ and $\mathrm{Pb}$ in whole blood volunteers

\begin{tabular}{|c|c|c|c|c|}
\hline \multirow[t]{2}{*}{ Sample } & \multirow[t]{2}{*}{$\mathrm{Cd}\left(\mu \mathrm{gL}^{-1}\right)$} & \multirow[t]{2}{*}{$\mathrm{Pb}\left(\mu \mathrm{g} \mathrm{L}^{-1}\right)$} & \multicolumn{2}{|l|}{ Recoveries (\%) } \\
\hline & & & Cd spike $\left(0.10 \mu \mathrm{g} \mathrm{L}^{-1}\right)$ & $\mathrm{Pb}$ spike $\left(2.5 \mu \mathrm{gL}^{-1}\right)$ \\
\hline 1 & $1.23 \pm 0.08$ & $34.4 \pm 0.9$ & 104 & 108 \\
\hline 2 & $0.61 \pm 0.11$ & $27.6 \pm 1.2$ & 115 & 102 \\
\hline 3 & $0.72 \pm 0.05$ & $39.1 \pm 3.9$ & 107 & 112 \\
\hline 4 & $0.78 \pm 0.06$ & $33.3 \pm 1.5$ & 98 & 99 \\
\hline Mean \pm S.D." $(n=40)$ & $0.32 \pm 0.19$ & $25.1 \pm 10.8$ & - & - \\
\hline
\end{tabular}

* S.D., Standard deviation.
Table 6

Blood lead levels (BLL) in adults of São Paulo city

\begin{tabular}{llcl}
\hline Year of publication & Total population & $\mathrm{Pb}\left(\mu \mathrm{g} \mathrm{L}^{-1}\right)$ & Reference \\
\hline 1981 & $n=63$ (men) & $142 \pm 43$ & {$[18,39]$} \\
& $n=37$ (women) & $93 \pm 39$ & \\
1985 & $n=26$ & $130 \pm 8$ & {$[40]$} \\
1997 & $n=30$ & $63.0 \pm 2.3$ & {$[41]$} \\
2007 & $n=40$ & $25.1 \pm 10.8$ & This work
\end{tabular}

2). Six separated samples of each CRM were prepared according to the proposed method and analyzed in triplicate. The repeatabilities ranged from 1.8 to $6.8 \%$ for $\mathrm{Cd}$ and 1.2 to $1.7 \%$ for $\mathrm{Pb}$. The reproducibility (between-day precision) of method was monitored by analysis of CRM (Lyphocheck ${ }^{\circledR}$ Whole Blood Metals Control level 1) over a 6-month period. The relative standard deviations of the results in this period of time were $10.2 \%$ for $\mathrm{Cd}$ and 8.8 for $\mathrm{Pb}$.

In Table 6 are showed the reference values for blood lead level (BLL), in adult population of São Paulo city (Brazil) obtained in different period of times 1981, 1985, 1997 and 2007. Brazil does not have a health public regular program for measuring the BLL in the general population. Therefore, data reported in Table 6 are individual studies to determine BLL for specific interest. But, it is evident the reduction of lead concentration in whole blood with the time, claiming for high sensible methods for quantitative determination.

Recently, studies coordinated by New York City Health and Nutrition Examination Survey (NYC HANES), from United States allowed assessing the environmental exposure of $\mathrm{Cd}$, $\mathrm{Hg}$ and $\mathrm{Pb}$ in blood of New York City adults. The geometric mean blood of these elements concentrations were 0.77 and $17.0 \mu \mathrm{g} \mathrm{L}^{-1}$, respectively. The authors comment that $\mathrm{Cd}$ concentration is slightly higher than the 1999-2000 national estimated for adults $\left(0.47 \mu \mathrm{g} \mathrm{L}^{-1}\right)$ [42].

\section{Conclusions}

The low dilution of blood samples $(1+4)$ combined with protein precipitation with TCA can be considered as the up-todate strategy for the simultaneous determination of $\mathrm{Cd}$ and $\mathrm{Pb}$ by SIMAAS to assess the environmental exposure. Additionally, the combination of permanent chemical modifier $(250 \mu \mathrm{g}$ $\mathrm{W}+200 \mu \mathrm{gh})$ and co-injected $2.0 \%\left(\mathrm{w} \mathrm{v}^{-1}\right)$ of $\mathrm{NH}_{4} \mathrm{H}_{2} \mathrm{PO}_{4}$ enlarged the graphite tube up to 846 heating cycles without 
long-term precision damage $(<21 \%$ for $\mathrm{Cd}$ and $<13 \%$ for $\mathrm{Pb})$ and reduced the matrix effects, respectively.

\section{Acknowledgements}

The authors are grateful to Fundação de Amparo à Pesquisa do Estado de São Paulo (FAPESP) for finacial support and for fellowship to ALS and Conselho Nacional de Desenvolvimento Científico e Tecnológico $(\mathrm{CNPq})$ for financial support. PVO is also thankful to Conselho Nacional de Desenvolvimento Científico e Tecnológico $(\mathrm{CNPq})$ by the researchship provided.

\section{References}

[1] N.C. Papanikolaou, E.G. Hatzidaki, S. Belivanis, G.N. Tzanakakis, A.M Tsatsakis, Med. Sci. Monitor 11 (2005) RA329.

[2] D.C. Bellinger, Pediatrics 113 (2004) 1016

[3] M.P. Waalkes, J. Inorg. Biochem. 79 (2000) 241.

[4] S.J. Stohs, D. Bagchi, Free Rad. Biol. Med. 18 (1995) 321.

[5] E. Rojas, L.A. Herrera, L.A. Poirier, P. Ostrosky-Wegman, Mutat. Res.Genet. Tox. Environ. Mutag. 443 (1999) 157.

[6] A.L. Mendelsohn, B.P. Dreyer, A.H. Firman, C.M. Rosen, L.A. Legano, H.A. Kruger, S.W. Lim, C.D. Courtlandt, Pediatrics 101 (1998) 1.

[7] W.I. Mortada, M.A. Sobh, M.M. El-Defrawy, S.E. Farahat, Environ. Res. 90 (2002) 104.

[8] P. Kakkar, F.N. Jaffery, Environ. Tox. Pharmacol. 19 (2005) 335.

[9] P. Boffetta, Mutat. Res.-Genet. Tox. Environ. Mutag. 608 (2006) 157.

[10] M. Wilhelm, C. Schulz, M. Schwenk, Int. J. Hyg. Environ. Health 209 (2006) 301.

[11] C.D. Palmer, M.E. Lewis Jr., C.M. Geraghty, F. Barbosa Jr., P.J. Parsons, Spectrochim. Acta Part B 61 (2006) 980.

[12] F. Barbosa Jr., J.E. Tanus-Santos, R.F. Gerlach, P.J. Parsons, Environ. Health Perspect. 113 (2005) 1669

[13] P. Apostoli, A. Baj, P. Bavazzano, A. Ganzi, G. Neri, A. Ronchi, L. Soleo, L. Di Lorenzo, P. Spinelli, T. Valente, C. Minoia, Sci. Total Environ. 287 (2002) 1.

[14] M. Cerna, V. Spevackova, M. Cejchanova, B. Benes, P. Rossner, D. Ocadilikova, J. Smid, Sci. Total Environ. 204 (1997) 263.

[15] E. Bárány, I.A. Bergdahl, L.E. Bratteby, T. Lundh, G. Samuelson, A. Shütz S. Skerfving, A. Oskarsson, Environ. Res. 89 (2002) 72.
[16] M. Wilhelm, G. Eberwein, J. Hölzer, J. Begerow, D. Sugiri, D. Gladtke, U. Ranft, J. Trace Elem. Med. Biol. 19 (2005) 83.

[17] M. Castelli, B. Rossi, F. Corsetti, A. Mantovani, G. Spera, C. Lubrano, L Silvestroni, M. Patriarca, F. Chlodo, A. Menditto, Microchem. J. 79 (2005) 349 .

[18] M.M.B. Paoliello, E.M. De Capitani, Environ. Res. 103 (2007) 288.

[19] H.I. Afridi, T.G. Kazi, M.K. Jamali, G.H. Kazi, M.B. Arain, N. Jalbani, G.Q. Shar, R.A. Sarfaraz, Toxicol. Ind. Health 22 (2006) 381.

[20] A.C. Davis, P. Wu, X.F. Zhang, X.D. Hou, B.T. Jones, Appl. Spectros. Rev. 41 (2006) 35 .

[21] M. Rose, M. Knaggs, L. Owen, M. Baxter, J. Anal. At. Spectrom. 16 (2001) 1101

[22] D.L. Tsalev, J. Anal. At. Spectrom. 9 (1993) 405.

[23] H.I. Afridi, T.G. Kazi, M.B. Arain, M.K. Jamali, G.H. Kazi, N. Jalbani, J. AOAC Int. 90 (2007) 470.

[24] A. Viitak, A.B. Volynsky, Talanta 70 (2006) 890.

[25] E.J. Daftsis, G.A. Zachariadis, Talanta 71 (2007) 722

[26] M. Stoeppler, K. Brandt, Fresenius J. Anal. Chem. 300 (1980) 372

[27] N. Campilo, P. Viñas, I. Lópes-García, M. Hernándz-Córdoba, Anal. Chim. Acta 390 (1999) 207.

[28] PJ. Parsons, W. Slavin, Spectrochim. Acta Part B 48 (1993) 925.

[29] C.R. dos Santos, R.S. Rodrigues, C.S. Silva, E.S. Nascimento, J. Radioanal. Nucl. Chem. 269 (2006) 481.

[30] M.A. White, A. Panayi, At. Spectros. 19 (1998) 89.

[31] A. Deval, J. Sneddon, Microchem. J. 52 (1995) 96.

[32] A. Viksna, E.S. Lindgren, Anal. Chim. Acta 353 (1997) 307.

[33] P.R.M. Correia, P.V. Oliveira, At. Spectrosc. 24 (2004) 222.

[34] P.R.M. Correia, P.V. Oliveira, J.A.G. Neto, J.A. Nóbrega, J. Anal. At. Spectrom. 19 (2004) 917.

[35] E.C. Lima, F.J. Krug, K.W. Jackson, Spectrochim. Acta Part B 53 (1998) 1791

[36] R.C. West (Ed.), Handbook of Chemistry and Physics, 66th ed., CRC Press, Boca Raton, FL, 1985.

[37] Y. Zhou, R.A. Zanão, F. Barbosa Jr., P.J. Parsons, F.J. Krug, Spectrochim. Acta Part B 57 (2002) 1291.

[38] F.J. Krug, M.M. Silva, P.V. Oliveira, J.A. Nóbrega, Spectrochim. Acta Part B 50 (1995) 1469

[39] N.A.G.G. Fernícola, F.A. Azevedo, Rev, Saúde Publ. 15 (1981) 272

[40] H.P. Monteiro, D.S.P. Abdalla, A.S. Arcuri, E.J.H. Bechara, Clin. Chem. 31 (1985) 1673

[41] C.A. Costa, G.C. Trivelato, A.M.P. Pinto, E.J.H. Bechara, Chin. Chem. 43 (1997) 1196

[42] W. Mckelvey, R.C. Gwynn, N. Jeffery, D. Kass, L.E. Thrope, R.K. Garg. C.D. Palmer, P.J. Parsons, Environ. Health Perspect. 115 (2007) 1435. 


\section{Anexo II}

\section{Questionário: Valores de referência para metais em sangue}

Posto de coleta:

Data:

Hora:

\section{I - Dados Pessoais (não preencher campos 2 a 7)}

1. Nome:

2. Data de nascimento: 119 anos) Sexo:

3. Raça: Estado Civil:

4. Nac:: Natural.:

5. Doc. N. : Tipo: Org. Exp.:

6. Escolaridade:

7. Endereço residencial (rua/n. $\left.{ }^{\circ}\right)$ Bairro:

Município: UF: CEP:

Telefone: Celular:

8. Você trabalha? Sim $\square \quad$ Não $\square \quad$ Desempregado/a

8.1 Se sim, o que você faz?

8.2 Há quanto tempo:

8.30 que você fazia antes?:

8.4 Por quanto tempo trabalhou?:

9. Alguém que vive na sua casa trabalha em fábrica de tintas, adubos, vidros, cerâmica,

plástico, conserto de baterias, galvanoplastia? Sim $\square \quad$ Não $\square$

10. Você tem alguma atividade de lazer/hobby? (pintura, cerâmica, pesca, tiro com arma de fogo)

11. Quantas pessoas vivem na sua casa?

12. Qual a renda da sua família? (salário mínimo $R \$ 350,00$ )

até $350,00 \square 351,00-2.100,00 \square 2.101,00-3.500,00 \square>3.501,00$

Não respondeu

13. Você come peixe, marisco, camarão? Sim

Não

13.1 Se sim, com que freqüência? diariamente $\square \quad$ 1x na semana mais de 1x na semana $\square \quad$ 1x ao mês $\square \quad 2$ a 3x ao mês

13.2 Você consumiu peixe, camarão, marisco nos últimos 2 dias? Sim 
14. Você bebe (bebida alcoólica)? $\operatorname{Sim}$ Não $\square$

14.1 Se sim, qual bebida? cerveja vinho destilados

14.2 Com que freqüência? diariamente $\square$ mais de $1 \times$ na semana $\square$ finais de semana $\square$ 15. Você toma remédios, chás, energéticos, vitaminas? Sim Não 15.1 Se sim, qual e há quanto tempo?

16. Você masca chicletes? Sim Não

16.1 Se sim, com que freqüência? diariamente $\square$ ocasionalmente 17. Você tem dentes com restaurações (obturações) de metal (amálgama)? Sim $\square \quad$ Não $\square \quad$ Não sei

18. Para a mulheres: Uso de anticoncepcional Menopausa Terapia de reposição hormonal

18.1 Data da última menstruação:

\section{II - Informações sobre a moradia}

19. Há quanto tempo reside no mesmo endereço?

20. Você reformou ou pintou a sua casa recentemente? Sim $\square \quad$ Não 20.1 Se sim, há quanto tempo?

21. A água de beber da sua casa é? Rede $\square$ Mineral $\square$ Poço $\square$ Outra:

22. Você tem horta em casa? $\operatorname{Sim} \square \quad$ Não $\square$

22.1 Você come as verduras da sua horta: Sim

Não

22.2 Qual a água que usa para irrigar a horta?

23. Tem alguma fábrica ou indústria perto da sua casa?: Sim $\square$ Não $\square$ Não sei 23.1 Se sim, qual e a distância da sua casa:

Entrevistador:

Reg. CETESB:

R.G. n. ${ }^{\circ}$ :

Dados complementares (não preencher)

Peso:

Pressão arterial:

Altura: Micro hematócrito:

Índice de massa corporal: 


\section{TERMO DE CONSENTIMENTO LIVRE ESCLARECIDO}

Eu, após ter sido informado sobre os objetivos da pesquisa, concordo em participar do Projeto Valores de Referência para Metais, do Setor de Toxicologia Humana e Saúde Ambiental da Companhia de Tecnologia de Saneamento Ambiental (CETESB).

Compreendo que a minha participação é inteiramente voluntária e estou ciente de que o meu nome e os dados que me identificam serão mantidos em sigilo pela equipe de pesquisadores, sendo garantidas a confiabilidade e a privacidade.

São Paulo, de de 2006.

Entrevistado

RG
Entrevistador

RG 


\section{Anexo III}

\section{Critérios de exclusão de doador}

Se o voluntário morar fora da Grande São Paulo, se doou sangue há menos de 6 meses ou se responder SIM a pelo menos uma pergunta abaixo, agradecer e dispensá-lo.

$1^{\circ}$ Há quanto tempo que o(a) sr(a) fez a última doação? (Pessoa que doou sangue há menos de 6 meses não pode participar do projeto)

$2^{\circ}$ - O sr (a) mora em qual cidade? (Ver tabela - Pessoa que mora em cidade que não pertence a Grande São Paulo não pode participar do projeto)

$3^{\circ}$ - O sr(a) trabalha com baterias, tintas, cerâmica, plástico, galvanoplastia, metalurgia, oficina mecânica, marcenaria, retificação de baterias, soldas? $\operatorname{Sim} \quad \square \quad$ Não $\square$ (Pessoa que trabalha nessas atividades não pode participar do projeto)

$4^{\circ}$ - O sr(a) fuma ou parou de fumar há menos de 1 ano? Sim Não (Pessoa que fuma ou parou de fumar há menos de 1 ano não pode participar do projeto)

Municípios da Grande São Paulo

\begin{tabular}{|l|l|}
\hline Arujá & Mairiporã \\
\hline Barueri & Mauá \\
\hline Biritiba Mirim & Mogi das Cruzes \\
\hline Caieiras & Osasco \\
\hline Cajamar & Pirapora do Bom Jesus \\
\hline Carapicuíba & Poá \\
\hline Cotia & Ribeirão Pires \\
\hline Diadema & Rio Grande da Serra \\
\hline Embu & Salesópolis \\
\hline Embu-Guaçu & Santa Isabel \\
\hline Ferraz de Vasconcelos & Santana de Parnaíba \\
\hline Francisco Morato & Santo André \\
\hline Franco da Rocha & São Bernardo do Campo \\
\hline Guararema & São Caetano do Sul \\
\hline Guarulhos & São Lourenço da Serra \\
\hline Itapecerica da Serra & São Paulo \\
\hline Itapevi & Suzano \\
\hline Itaquaquecetuba & Taboão da Serra \\
\hline Jandira & Vargem Grande Paulista \\
\hline Juquitiba & \\
\hline & \\
\hline
\end{tabular}




\section{Anexo IV}

\section{Aprovação da CAPPesq}

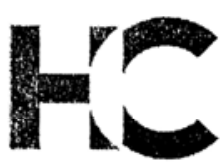

\section{APROVAÇÃO}

A Comissão de Ética para Análise de Projetos de Pesquisa - CAPPesq da Diretoria Clínica do Hospital das Clínicas e da Faculdade de Medicina da Universidade de São Paulo, em sessão de 14.06.06, APROVOU Protocolo de Pesquisa $n^{\circ}$ 473/06 intitulado: "Contribuição para o estabelecimento de valores de referência para chumbo e cádmio em sangue da população adulta da Região Metropolitana de São Paulo, apresentando pelo Departamento de Medicina Preventiva, inclusive Termo de Consentimento Livre e esclarecido.

Cabe ao pesquisador elaborar e apresentar à CAPPesq, os relatórios parciais e final sobre a pesquisa (Resolução do Conselho Nacional de Saúde $n^{\circ} 196$, de 10.10.1996, inciso IX. 2, letra "c")

Pesquisador(a) Responsável: Prof.Dr.Nelson da Cruz Gouveia Pesquisador(a) Executante: RubiA Kuno

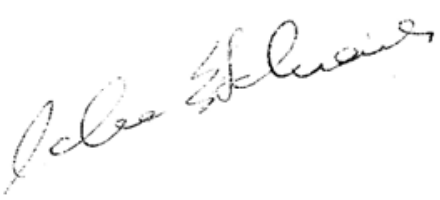

CAPPesq, 14 de Junino de 2006.

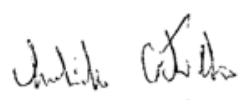

PROF. DR. EUCLIDES AYRES DE CASTILHO

Presidente da Comissão de Ética para Análise de Projetos de Pesquisa

Conissãc de Étice paro Análise de Projetos de Pesquisa do HCFMus? e da FMSs? Siretoria Clínica do hiospital das Clinicas da Faculdade de Medicina da Liniversidade die Sún fouto Eua Ovídio Pires de Compos. 225, $5^{\circ}$ andar - CEP 05403010 - 500 Pculo - SP 


\section{Anexo V}

\section{Aprovação da CONEP}

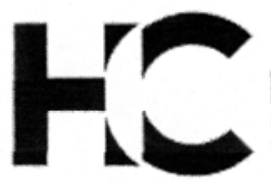

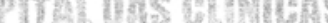

DA. FACULDADE DE MAEOICINA

Memo.CAPPesq-044/07

São Paulo, 12 de abril de 2007.

IImo. Sr.

Dr. Nelson da Cruz Gouveia

DD. Pesquisador

Departamento de Medicina Preventiva

Por determinação do Senhor Presidente, Prof. Dr. Eduardo Massad, encaminhamos para conhecimento, cópia do parecer $n^{\circ}$ 332/2007, da Comissão Nacional de Ética em Pesquisa CONEP/MS referente à APROVACÃO do protocolo de Pesquisa $n^{\circ}$ 1166/06 - intitulado "Contribuição para o escalonamento de valores de referência para mercúrio em sangue da população adulta da região metropolitana de São Paulo".

Atenciosamente,

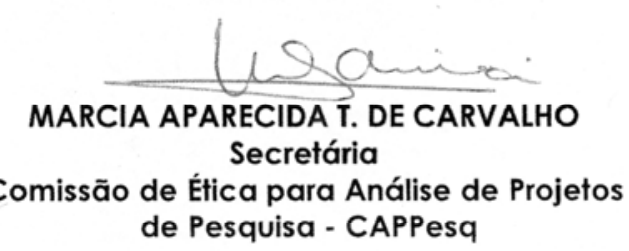


MINISTÉRIO DA SAÚDE

Conselho Nacional de Saúde

Comissáo Nacional de Ética em Pesquisa - CoNEp

PARECER N $332 / 2007$

Registro CONEP:13600 (Este n deve ser cltado nas correspondências refersntes a esto projeto)

CAAE- $0960.0 .015 .000-06$

Processo n ${ }^{\circ}$ 25000.201.168/2006-65

Projeto de Pesquisa: "Contribuição para o estabelecimento de valores de referência para mercúrio em sangue da população adulta da Região Metropolitana de Säo Paulo".

Pesquisador Responsável: Dr. Nelson da Cruz Gouveia

Instituiçäo: HCFMUSP - Hospital das Clínicas da Faculdade de Medicina da Universidade de Säo Paulo

CEP de origem: HCFMUSP - Hospital das Clínicas da Facuidade de Medicina da Universidade de Säo Paujo

Área Temática Especial: Cooperaçäo Estrangeira.

Patrocinador: CETESB - Companhia de Tecnologia de Saneamento Ambiental

\section{Sumárlo Geral do Protocolo}

O objetivo geral da pesquisa é contribuir para o estabelecimento de valores de referência para mercúrio no sangue de adultos, sem exposição ocupacional a esse metal, residentes na Regiāo Metropolitana de Săo Pauio.

Trata-se de estudo de corte transversal, onde serão coletadas cerca de 800 amostras de sangue ( $6 \mathrm{ml}$ cada) de doadores de sangue da Associaçăo Beneficente de Coleta de Sangue (Hemo-rede-SUS/SP) para análise de mercúrio.

o grupo amostral será composto por doadores de ambos os sexos, com idades variando de 18 a 64 anos 9 residentes na RMSP.

No momento da coleta será aplicado um questionário ao doador para obter informaçöes sobre possiveis exposiçöes ambientais, hábitos pessoais como tipo de alimentaçäo, origern da água que beber, dentre outras que vão auxiliar na análise e interpretação dos resultados.

As amostras de sangue serão coletadas em tubos a vácuo heparinizados e encaminhadas ao laboratório da Agência Ambiental Federal da Alemanha (UBA) өm Berlim, onde serão analisadas (conforme carta anexa), como parte de projeto de cooperaçäo técnica entre a Agência Ambiental Alemā $\ominus$ a Cetesb, pois a agência paulista näo dispōe atualmente de metodologia analítica para análise de mercúrio em sangue $\theta$ o projeto de cooperação prevê a realizaçăo das análises pela Agência alemă, sem custo para a Cetesb. 
Cont, Parecor CONEP 332/07

Ao se proceder à análise das iespostas ao parecer CONEP no

:14/2007, relativo ao projeto em questäo, considerou-se que:

1. As modificaçôes suggeridas ao Temo de Consentimento Livre EsciarocidoTCLE foram acatadas e nova versân foi apresentada.

2. Foi inciuído novo cronograma e orçemento detalhedo do projeto.

3. Foi esclarecido que năo haverá formaçâo de banco com o material gue será descartado após análise. Havará envio de amostras para a Agência Ambiental Alemä para determinaçăo de nercúrio nas amostras, que serẫo descartadas. Tais aspectos foram inclúdos no projeto $(0.16$ e 17$)$, onde consta que 0 envio das amostras para a Alemanha, inclúfos os custos envolvidos que seré do responsabilidade do Setor de Toxicclogia Humana e Saúde Ambiental da Cetesb.

Diante do exposto, ä Comissäo Nacionả de Ética em Pesquisa CONEP, de acordo com as atribuäȩöes definidas na Res. CNS 196/96, mantriesta - se pela aprovação do projesto de pesquisa proposâto.

\section{Situaçăo : Projeto aprovado}

Brasíiliz, 10 de abril de 2007.
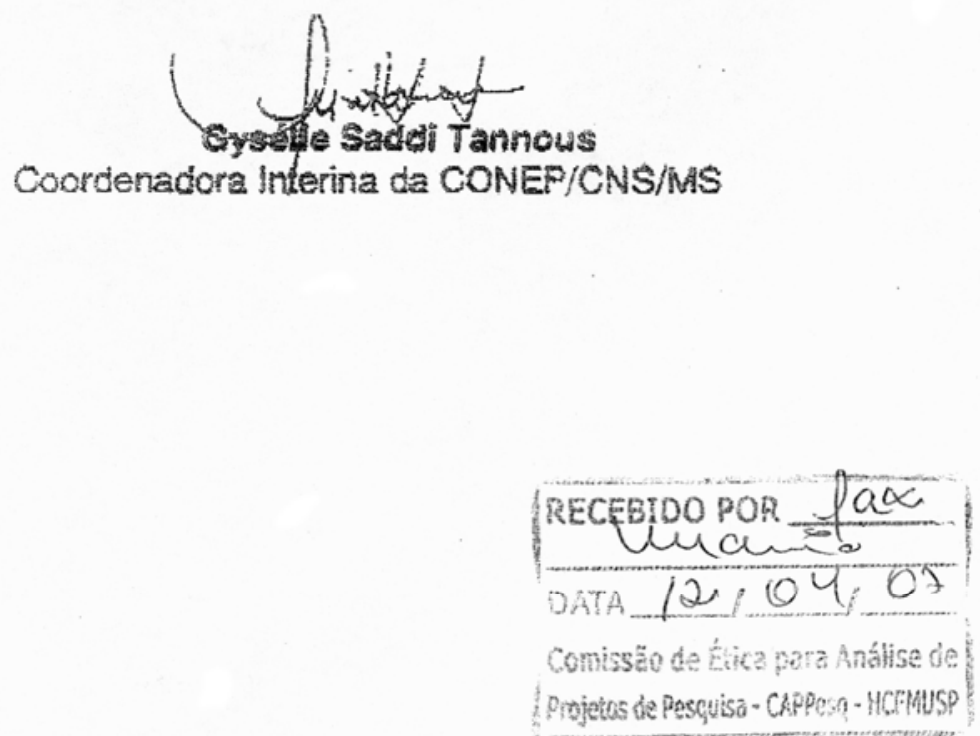


\section{REFERÊNCI AS}

Agency for Toxic Substances and Disease Registry. Toxicological profile for cadmium. Atlanta: ATSDR, 1997.

Agency for Toxic Substances and Disease Registry. Toxicology Profile for Lead. Atlanta: ATSDR, 1999a.

Agency for Toxic Substances and Disease Registry. Toxicological profile for cadmium. Atlanta: ATSDR, 1999b.

Agency for Toxic Substances and Disease Registry. Toxicology Profile for Mercury. Atlanta: ATSDR, 1999c.

Agency for Toxic Substances and Disease Registry. Toxicology Profile for Lead. Atlanta: ATSDR, 2007.

Alessio L. Reference values for the study of low doses. Sci Total Environ. 1992; 120:1-6.

American Conference of Government Industrial Hygienists. 2005 TLVs e BEIs - Threshold limit values for chemical substances and physical agents and biological exposure indices. Tradução da Associação Brasileira de Higienistas Ocupacionais. São Paulo: ABHO; 2005.

Apostoli P. Application of reference values in occupational health. Int Arch Occup Environ Health. 1999; 72: 191-4. 
Apostoli P. Criteria for the definition of reference values for toxic metals. Sci Total Environ. 1992; 120: 23-37.

Apostoli P. Elements in environmental and occupational medicine. J Chromatogr B. 2002; 778: 63-97.

Apostoli P, Alessio L. Identification of Reference Values for Metals in the General population. Rev Bras Toxicol. 1991. 4: 7-10.

Apostoli P, Baj A, Bavazzano P, Ganzi A, Neri G, Ronchi A, Soleo L, Di Lorenzo L, Spinelli $P$, Valente T, Minoia C. Blood lead reference values: the results of na Italian polycentric study. Sci Total Environ. 2002; 287: 1-11.

Apostoli P, Maranelli G, Micciolo R. Is hypertension a confounding factor in the assessment of blood lead reference values? Sci Total Environ. 1992; 120: $127-134$.

Azevedo FA. Toxicologia do Mercúrio. São Carlos: RiMa; 2003. São Paulo: InterTox; 2003.

Bæcklund M, Pedersen NL, Björkman L, Vahter M. Variation in blood concentrations of cadmium and lead in the elderly. Environ Res. 1999; 80: $222-30$.

Barry PSI. A comparison of concentrations of lead in human tissues. $\mathrm{Br} \mathrm{J}$ Ind Med. 1975; 32: 119-39.

Batáriová A, Spevácková V, Benes $B$, Cejchanová $M$, Smĺd J, Cerná M. Blood and urine levels of $\mathrm{Pb}, \mathrm{Cd}$, and $\mathrm{Hg}$ in the general population of the Czech Republic and proposed reference values. Int J Hyg Environ Health. 2006; 209: 359-66. 
Bellinger DC, Daniel D, Trachtenberg F, Tavares M, Mckinlay S. Dental amalgam restorations and children's neuropsychological function: The New England children's amalgam trial. Environ Health Perspec. 2007; 115: 440-6.

Bono R, Pignata C, Scursatone E, Rovere R, Natale P, Gilli G. Updating about Reductions of Air and Blood Lead Concentrations in Turin, Italy, Following Reductions in the Lead Content of Gasoline. Environ Res. 1995; 70: 30-4.

Boogaard PJ. Human biomonitoring activities - programmes by industry. Int $\mathrm{J}$ Hyg Environ Health. 2007; 210: 259-61.

BRAGA, M. Non-parametric age related centile curves for blood lead levels in blood donors from Northern Italy. Sci Total Environ. 1992; 120: 173-84.

Brasil. Agência Nacional de Vigilância Sanitária. Resolução RE n. 899, de 29 de maio de 2003. Determina a publicação do "Guia para validação de métodos analíticos e bioanalíticos”. Diário Oficial da União, Brasília (DF). 200302 jun.

Brasil. Conselho Nacional do Meio Ambiente. Resolução n. 3 de 28 de junho de 1990. Dispõe sobre padrões de qualidade do ar, previstos no PRONAR. Diário Oficial da União, Brasília (DF). 199022 ago.; Seção 1: 15937-9.

Buchet JP, Lauwerys R, Roels H, Bernard A, Bruaux P, Claeys F, Ducoffre G, De Plaen P, Staessen J, Amery A, Lijnen P, Thijs L, Rondia D, Sartor F, Saint Remy A, Nick L. Renal effects of cadmium body burden of the general population. The Lancet. 1990; 336: 699-702.

Canuel R, Grosbois SB, Atikessé L, Lucotte M, Arp P, Ritchie C, Mergler D, Chan HM, Amyot M, Anderson R. New Evidence on Variations of Human Body Burden of Methylmercury from Fish Consumption. Environ Health Perspect. 2006; 114: 302-6. 
Casteleyn L, Van Tongelen B. Reis MF, Polcher A, Joas R. Human biomonitoring: towards more integrated approaches in Europe [editorial]. Int $\mathrm{J}$ Environ Health. 2007; 210: 199-200.

Centers for Disease Control and Prevention. Third National Report on Human Exposure to Environmental Chemicals [Internet]. EUA: CDC; 2005a [citado 24 out 2005]. Disponível em: http://www.cdc.gov/exposurereport.

Centers for Disease Control and Prevention. Preventing Lead Poisoning in Young Children. Atlanta: CDC; 2005b. Disponível em: http://www.cdc.gov/nceh/lead/publications/PrevLeadPoisoning.pdf

Černá $M$, Spěváčková V, Batáriová $A$, Šmíd J, Čejchanová M, Očadlíková $D$, Bavorová $H$, Beneš $B$, Kubĺnova R. Human biomonitoring system in the Czech Republic. Int J Hyg Environ Health. 2007; 210: 495-9.

Chasin AAM, Cardoso LMN. Cádmio. In: Azevedo FA, Chasin AAM. eds. Metais: Gerenciamento da Toxicidade. São Paulo: Editora Atheneu, 2003. p.263-98.

Clarkson TW. The three faces of mercury. Environ Health Perspect. 2002; 110:11-23.

Companhia de Tecnologia de Saneamento Ambiental. Relatório de qualidade de águas subterrâneas no Estado de São Paulo 2001-2003 [online]. São Paulo: CETESB; 2004 [citado 19 ago 2008]. Disponível em: http://www.cetesb.sp.gov.br/Solo/publicacoes.asp.

Companhia de Tecnologia de Saneamento Ambiental. Relatório de qualidade das águas interiores no Estado de São Paulo 2005 [online]. São Paulo: CETESB; 2006 [citado 28 jul 2008]. Disponível em: http://www.cetesb.sp.gov.br/Agua/rios/publicacoes.asp 
Companhia de Tecnologia de Saneamento Ambiental - Relação de áreas contaminadas do Estado de São Paulo [Internet]. 2007a Novembro [citado 08 abr 2008]. Disponível em: www. cetesb.sp.gov.br/solo/areas_contaminadas/relacao_areas.htm.

Companhia de Tecnologia de Saneamento Ambiental. Relatório de qualidade das águas interiores no Estado de São Paulo 2006 [online]. São Paulo: CETESB; 2007b [citado 28 jul 2008]. Disponível em: http://www.cetesb.sp.gov.br/Agua/rios/publicacoes.asp

Companhia de Tecnologia de Saneamento Ambiental. Relatório de qualidade de águas subterrâneas no Estado de São Paulo 2004-2006 [online]. São Paulo: CETESB; 2007c [citado 19 ago 2008]. Disponível em: http://www.cetesb.sp.gov.br/Solo/publicacoes.asp.

Companhia de Tecnologia de Saneamento Ambiental. Relatório de qualidade das águas interiores no Estado de São Paulo 2007 [online]. São Paulo: CETESB; 2008a [citado 28 jul 2008]. Disponível em: http://www.cetesb.sp.gov.br/Agua/rios/publicacoes.asp.

Companhia de Tecnologia de Saneamento Ambiental. Valores da Condição de Qualidade dos Solos da Bacia Hidrográfica do Alto Tietê - UGRHI 6 e da Região Metropolitana de São Paulo - RMSP/ CETESB. São Paulo: CETESB, 2008b. 70P.

Correia PRM, Oliveira PV. A fast procedure for the simultaneous determination of $\mathrm{Cd}$ and $\mathrm{Pb}$ in whole blood by electrothermal atomic absorption spectrometry. Atomic Spectroscopy. 2003;24(6):222-6.

Decaprio AP. Biomarkers: coming of age for environmental health and risk assessment. Environ Sci Technol. 1997; 31:1837-48. 
Della Rosa VH, Siqueira MEPB, Colacioppo S. Monitoramento ambiental e biológico. parte 3: toxicologia ocupacional. In: Oga S, Camargo MMA, Batistuzzo JAO. editores. Fundamentos de Toxicologia, 3a ed. São Paulo: Atheneu; 2008. p. 241-60.

Dias CL. Informações sobre resultados de mercúrio e chumbo nos poços da região metropolitana de São Paulo. claudio@cetesbnet.sp.gov.br [mensagem pessoal] [citado 19 ago 2008]. E-mail para Rúbia Kuno (rubiak@cetesbnet.sp.gov.br).

Dickman MD, Leung KMC. Mercury and organochlorine exposure from fish consumption in Hong Kong. Chemosphere. 1998; 37: 991-1015.

Djalali M, Neyestani TR, Bateni J, Siassi F. The effect of repeated blood donations on the iron status of Iranian blood donors attending the Iranian blood transfusion organization. Int J Vitam Nutr Res. 2006; 76: 132-7.

Duca P. Statistical aspects of the estimation of reference limits. Sci Total Environ. 1992; 120: 155-71.

Ducoffre G, Claeys F, Bruaux P. Lowering time trend of blood lead levels in Belgium since 1978. Environ Res. 1990; 51: 25-34.

Dybkaer R, Solberg HE. Approved recommendation (1987) on the theory of reference values. Part 6 . Presentation of observed values related to reference values. Clin Chim Acta. 1987; 170: S33-S42.

Eurachem. The fitness for purpose of analytical methods. A laboratory guide to method validation and related topics. $1^{\text {st }}$ ed. United Kingdom: LGC (Teddington) Ltd; 1998. 
Ewers U, Krause C, Schulz C, Wilhelm M. Reference values and human biological monitoring values for environmental toxins. Report on the work and recommendations of the Commission on Human Biological Monitoring of the German Federal Environmental Agency. Int Arch Occup Environ Health. 1999; 72: 255-60.

Fernicola NAGG, Azevedo FA. Níveis de chumbo e atividade da desidratase do ácido $\delta$-aminolevulínico ( $\delta$-ALAD) no sangue da população da Grande São Paulo, Brasil. Rev. Saúde públ. 15: 272-82, 1981.

Fleming DEB, Boulay D, Richard NS, Robin J-P, Gordon CL, Webber CE, Chettle DR. Accumulated Body Burden and Endogenous Release of Lead in Employees of a Lead Smelter. Environ Health Perspect. 1997; 105: 224-33.

Garrido Latorre F, Hernández-Avila M, Tamayo Orozco J, Albores Medina $\mathrm{CA}$, Aro A, Palazuelos $\mathrm{E}, \mathrm{Hu} \mathrm{H}$. relationship pf Blood and Boné Lead to Menopause and Boné Mineral Density among Middle-Age Women in México City. Environ Health Perspec. 2003; 111: 631-6.

Gerhardsson L, Kazantzis G, Schütz, A. Evaluation of selected publications on reference values for lead in blood. Scand J Work Environ Health. 1996; 22: $325-31$.

Grasbeck R, Saris ME. Establishment and use of reference values. Scand J Clin Lab Invest Suppl. 1969; 24: 62-3.

Grasbeck R. Reference values, why and how. Scand J Clin Lab Invest Suppl. 1990; 50: 45-53.

Gulson BL, Jameson CW, Mahaffey KR, Mizon KJ, Korsch MJ, Vimpani G. Pregnancy increases mobilization of lead from maternal skeleton. $\mathrm{J}$ Lab Clin Med. 1997; 130: 51-62. 
Gulson BL, Mizon KJ, Korsch MJ, Palmer JM, Donnelly JB. Mobilization of lead from human bone tissue during pregnancy and lactation - a summary of long-term research. Sci Total Environ. 2003; 303: 79-104.

Gulson BL, Mizon KJ, Palmer JM, Korsch MJ, Taylor AJ. Contribution of lead from calcium supplements to blood lead. Environ Health Perspect. 2001; 109 : 283-8.

Gulson BL, Mizon KJ, Palmer JM, Korsch MJ, Taylor AJ, Mahaffey KR. Blood Lead Changes during Pregnancy and Postpartum with Calcium Supplementation. Environ Health Perspect. 2004; 112: 1499-507.

Gulson BL, Pounds JG, Mushak P, Thomas BJ, Gray B, Korsch MJ. Estimation of cumulative lead releases (lead flux) from the maternal skeleton during pregnancy and lactation. J Lab Clin Med. 1999; 134: 631-40.

Gundacker C, Komarnicki G, Zödl B, Forster C, Schuster E, Wittmann K. Whole blood mercury and selenium concentrations in a selected Australian population: Does gender matter? Sci Total Environ. 2006; 372: 76-86.

Hansen ÅM, Garde AH, Eller NH. Estimation of individual reference intervals in small sample sizes. Int J Hyg Environ Health. 2007; 210: 471-8.

Hense HW, Filipiak B, Novak L, Stoeppler M. Nonoccupational determinants of blood lead concentrations in general population. Int J Epidemiol. 1992; 21: 753-62.

Hernadez-Avila M, Villalpando CG, Palazuelos E, Hu H, Villalpando MEG, Martinez DR. Determinants of blood lead levels across menopausal transition. Arch Environ Health. 2000; 55: 355-360. 
Hrnčírová $M$, Batáriová $A$, Černá $M$, Procházka $B$, Dlouhý $P$, Anděl $M$. Exposure of Prague s homeless population to lead and cadmium, compared to Prague s general population. Int J Hyg Environ Health. 2008; 211: 580-6.

Hu H, Shih R, Rothenberg S, Schwartz BS. The Epidemiology of Lead Toxicity in Adults: Measuring Dose and Consideration of Other Methodologic Issues. Environ Health Perspect. 2007; 115: 455-62.

Instituto Nacional de Metrologia, Normalização e Qualidade Industrial. Orientação sobre Validação de Métodos de Ensaios Químicos [Internet]. DOQ/CGCRE - 008 - Revisão 02; 2007 [citado 22 jan 2008]. Disponível em: http://www.inmetro.gov.br/Sidoq/Arquivos/CGCRE/DOQ/DOQ-CGCRE8 02.pdf

Jusko TA, Henderson Jr CR, Lanphear BP, Cory-Slechta DA, Parsons PJ, Canfield RL. Blood Lead Concentrations $<10 \mathrm{ug} / \mathrm{dL}$ and Child Intelligence at 6 Years of Age. Environ Health Perspect. 2008; 116: 243-8.

Kliment V. Ed. System of Monitoring the Environmental Impact on Population Health of the Czech Republic. Summary report 1999. Nacional Institute of Public Health, Prague. Prague, August 2000. Disponivel em: http://www.szu.cz/topics/environmental-health/environmental-healthmonitoring.

Kosnett MJ, Wedeen RP, Rothenberg SJ, Hipkins KL, Materna BL, Schwartz BS, $\mathrm{Hu} \mathrm{H}$, Woolf A. Recommendations for Medical Management of Adult Lead Exposure. Environ Health Perspect. 2007; 115: 463-71.

Kucera J, Bencko V, Sabbioni E, Van der Venne MT. Review of trace elements in blood, serum and urine for the Czech and Slovak populations and critical evaluation of their possible use as reference values. Sci Total Environ. 1995; 166: 211-34. 
Kummrow F, Silva FF, Kuno R, Souza AL, Oliveira PV. Biomonitoring method for the simultaneous determination of cadmium and lead in whole blood by electrothermal atomic absorption spectrometry for assessment of environmental exposure. Talanta. 2008; 75: 246-52.

Kuno R, Oliveira Filha MT, Sitnik RH. Níveis de plumbemia de um grupo populacional próximo à Indústria Incometal - Pindorama - SP. São Paulo: CETESB; 1994. Relatório técnico.

Kuno R, Roquetti-Humaytá MH, Oliveira Filha MT. Níveis de plumbemia em um grupo populacional e animais de propriedades vizinhas à Indústria Tonolli S/A - Jacareí (SP). São Paulo: CETESB; 1995. Relatório técnico.

Kuno R, Roquetti-Humaytá MH, Kummrow F, Kitano GM, Silva FF, Yanagi Y. Factors Related to Blood Lead Levels in a Group of Individuals without Occupational Exposure.( Abstracts - XI International Congress of Toxicology; 2007 July 14-21; Montreal, Canada).

Lagerkvist BJ, Ekesrydh S, Englyst V, Nordberg GF, Söderberg H-Å, Wiklund D-E. Increased blood lead and decreased calcium levels during pregnancy: a prospective study of Swedish women living near a smelter. Am J Public Health. 1996; 86: 1247-52.

Lee M, Chun OK, Song WO. Determinants of the Blood Lead Level of US Women of Reproductive Age. J Am Coll Nutr. 2005; 24: 1-9.

Levy LS, Jones K, Cocker J, Assem FL, Capleton AC. Background levels of key biomarkers of chemical exposure within the UK general population - Pilot study. Int J Hyg Environ Health. 2007; 210: 387-91. 
Liu J, Goyer RA, Waalkes MP. Toxic Effects of Metals. In: Klaassen CD. Casarett and Doull's Toxicology - The Basic Science of Poisons. 7a ed. New York: The McGraw-Hill Companies; 2008. p. 931-79.

Lopes CFF, Oliveira MCN, Martins MHRB. Evolução das concentrações de chumbo na atmosfera da RMSP. (Resumos do $14^{\circ}$ Encontro Nacional de Química Analítica. 2007 Outubro 7-11; João Pessoa, PB).

Lustigová M, Puklová V. editors. Environmental Health Monitoring System in the Czech Republic. Summary report - 2005. National Institute of Public Health. $2006 . \quad$ Prague. Disponível em: http://www.szu.cz/topics/environmental-health/environmental-health$\underline{\text { monitoring }}$

Mahaffey KR. Predicting Blood Lead Concentrations from Lead in Environmental Media. Environ Health Perspect. 1998; 106: 1485-93.

Maranelli G, Apostoli P, Ferrari P. Influence of Smoking, Alcohol, and Dietary Habits on Blood Pb and Cd levels. Bul Environ Contam Toxicol. 1990; 45: 804-10.

McKelvey W, Gwynn RC, Jeffery N, Kass D, Thorpe LE, Garg RK, Palmer CD, Parsons PJ. A biomonitoring study of lead, cadmium, and mercury in the blood of New York City adults. Environ Health Perspect. 2007; 115: 1435-41.

MERCOSUL. Resolução GMC 45/96. Regulamento Vitivinícola do MERCOSUL. Buenos Aires. 199621 abr.

Mergler D, Anderson HA, Chan LHM, Mahaffey KR, Murray M, Sakamoto M, Stern AH. Methylmercury Exposure and Health Effects in Humans: A Worldwide Concern. Ambio. 2007; 36: 3-11. 
Minoia C, Sabbioni E, Apostoli P, Pietra R, Pozzoli L, Gallorini M, Nicolaou G, Alessio L, Capodaglio E. Trace element reference values in tissues from inhabitants of the European Community . I. A study of 46 elements in urine, blood and serum of Italian subjects. Sci Total Environ. 1990; 95: 89-105.

Morales LS, Gutierrez P, Escarce JJ. Demographic and socioeconomic factors associated with blood lead levels among mexican-american children and adolescents in the United States. Public Health Rep. 2005; 120: 448-54.

Moreira FR, Moreira JC. A cinética do chumbo no organismo humano e sua importância para a saúde. Ciênc. saúde coletiva. 2004; 9: 167-81.

Muntner P, Menke A, De Salvo KB, Rabito FA, Batuman V. Continued decline in blood levels among adults in the United States: The National and Nutrition Examination Surveys. Arch Intern Med. 2005; 165: 2155-61.

Mutti A. Biological monitoring in occupational and environmental toxicology. Toxicol Lett. 1999; 108: 77-89.

Nash D, Magder L, Lustberg M, Sherwin RW, Rubin RJ, Kaufmann RB, Silbergeld EK. Blood lead, blood pressure, and hypertension in perimenopausal and postmenopausal women. JAMA. 2003; 289: 1523-32.

National Research Council. The Committee on Biological Markers. Biological Markers in Environmental Health Research. Environ Health Perspect. 1987; 74: 3-9.

Navas-Ancien A, Guallar E, Silbergeld EK, Rothenberg SJ. Lead Exposure and Cardiovascular Disease - A Systematic Review. Environ Health Perspect. 2007; 115: 472-82. 
Nawrot TS, Staessen JA. Low-level environmental exposure to lead unmasked as silent killer. Circulation. 2006; 114: 1347-9.

Nogueira DP, Colacioppo S, Souza JMP, Pezza CB, Souza MLA, Gomes JR. Taxa de chumbo em amostra de voluntários "não expostos" habitantes da Grande São Paulo - Brasil. Rev. Saúde públ., 13:147-50, 1979.

Nordberg G. Human biomonitoring of trace elements - continued need for critical evaluation. Scand J Work Environ Health. 1996; 22: 321-324.

Nordberg G, Brune D, Gerhardsson L, Grandjean P, Vesterberg O, Wester PO. The ICOH and IUPAC international programme for establishing reference values of metals. Sci Total Environ. 1992; 120: 17-21.

Oskarsson A, Schültz A, Skerfving S, Hallén IP, Ohlin B, Lagerkvist BJ. Total and inorganic mercury in breast milk in relation to fish consumptionand amalgam in lactating women. Arch Environ Health. 1996; 51: 234-41.

Paoliello MMB, De Capitani EM. Chumbo. In: Azevedo FA, Chasin AAM. Eds. Metais: gerenciamento da toxicidade. São Paulo: Editora Atheneu, 2003. p. 353-98.

Paolielo MMB, De Capitani EM, Cunha FG, Carvalho MF, Matsuo T, Sakuma A, Figueiredo BR. Determinants of blood lead levels in na adult population from a mining área in Brazil. J Phys IV France. 2003; 107: 127-30.

Paoliello MMB, De Capitani EM. Occupational and environmental human lead exposure in Brazil. Environ Res. 2007; 103: 288-297.

Paolielo MMB, Gutierrez PR, Turini CA, Matsuo T, Mezzaroba L, Barbosa DS, Alvarenga ALP, Carvalho SRQ, Figueiroa GA, Leite VGM, Gutierrez AC, 
Nogueira KB, Inamine WAS, Zavatti AM. Valores de referência para plumbemia em população urbana. Rev Saude Publica. 1997; 31:44-8.

Paoliello MMB, Gutierrez PR, Turini CA, Matsuo T, Mezzaroba L, Barbosa DS, Carvalho SRQ, Alvarenga ALP, Rezende MA, Figueiroa GA, Leite VGM, Gutierrez AC, Lobo BCR, Cascales RA. Valores de referência para plumbemia em uma população urbana do Sul do Brasil. Rev Panam Salud Publica. 2001; 9: 315-9.

PetitClerc C, Solberg HE. Approved recommendation (1987) on the theory of reference values. Part 2. Selection of individuals for the production of reference values. Determination of reference limits. Clin Chim Acta. 1987; 170: S3-S12.

Poulsen OM, Holst E, Christensen JM. A supplement to the approved IFCC recommendation on the theory of reference values. Pure Appl. Chem. 1997; 69: 1601-11.

Puklová V. ed. Environmental Health Monitoring System in the Czech Republic. Summary report - 2007. $1^{\text {st }}$ edition. National Institute of Public Health, Prague. Prague, 2008. 108p. Disponível em : http://www.szu.cz/topics/environmental-health/environmental-healthmonitoring

Reed AH, Henry RJ, Mason WB. Influence of Statistical Method Used on the Resulting Estimate of Normal Range. Clin Chem. 1971; 17: 275-84.

Rosalém A. Associação entre fatores ambientais de exposição ao chumbo e plumbemia com abortamento espontâneo [tese]. Campinas: Faculdade de Ciências Médicas, Universidade Estadual de Campinas; 2004. 
Rothenberg SJ. Blood lead levels in children [letter]. Environ Health Perspect. 2008; 116 : A 472.

Rothenberg SJ, Karchmer S, Schnaas L, Perroni E, Zea F, Alba JF. Changes in a serial blood lead levels during pregnancy. Environ Health Perspect. 1994; 102: 876-80.

Sällsten G, Thorén J, Barregård L, Schütz A, Skarping G. Long-term use of nicotine chewing gum and mercury exposure from dental amalgam fillings. $J$ Dent Res. 1996; 75: 594-8.

Sabbioni E, Minoia C, Pietra R, Fortaner S, Gallorini M, Saltelli A. trace element reference values in tissues from inhabitants of the European Community. II. Exemples of strategy adopted and trace element analysis of blood, lymph nodes and cerebrospinal fluid of Italian subjects. The Sci Total Environ. 1992; 120: 30-62.

Sällsten G, Thorén J, Barregård L, Schütz A, Skarping G. Long-term use of nicotine chewing gum and mercury exposure from dental amalgam fillings. $J$ Dent Res. 1996;75: 594-8.

Satarug S, Moore MR. Adverse health effects of chronic exposure to lowlevel cadmium in foodstuffs and cigarette smoke. Environ Health Perspect. 2004; 112: 1099-103.

Satarug S, Ujjin P, Vanavanitkun Y, Baker JR, Moore MR. Influence of body iron store status and cigarette smoking on cadmium body burden of health Thai womem and men. Toxicol Lett. 2004; 148: 177-85.

Schroijen C, Baeyens W, Schoeters G, Den Hond E, Koppen G, Bruckers L, Nelen V, Van De Mieroop E, Bilau M, Covaci A, Keune H, Loots I, Kleinjans J, 
Dhooge W, Van Larebeke N. Internal exposure to pollutants measured in blood and urine of Flemish adolescents in function of area of residence. Chemosphere. 2008; 71: 1317-25.

Schulz C, Angerer J, Ewers U, Kolossa-Gehring M. The german human biomonitoring commission. Int J Hyg Environ Health. 2007a; 210: 373-82.

Schulz C, Conrad A, Becker K, Kolossa-Gehring M, Seiwert M, Seifert B. Twenty years of the German Environmental Survey (GerES): human biomonitoring - temporal and spatial (West Germany/East Germany) differences in population exposure. Int J Environ Health. 2007b; 210: 271-97.

Solberg HE. Approved recommendation (1986) on the theory of reference values. Part 1. The concept of reference values. Clin Chim Acta. 1987a ; 165:111-8.

Solberg HE. Approved recommendation (1987) on the theory of reference values. Part 5. Statistical treatment of collected reference values. Determination of reference limits. J Cin Chem Clin Biochem. 1987b; 170: S13-S32.

Sørensen N, Murata K, Budtz-Jørgensen E, Weihe P, Grandjean P. Prenatal methylmercury exposure as a cardiovascular risk factor at seven years of age. Epidemiology. 1999; 10: 370-5.

Trochim, William M. The Research Methods Knowledge Base, 2nd Edition. [on line]. Disponível em: <http://www.socialresearchmethods.net/kb/> (versão October 20, 2006).

U. S. EPA. United States Environmental Protection Agency. Air Quality Criteria for Lead. Volume I. 2006. [on line]. Disponível em: http://cfpub.epa.gov/ncea/cfm/recordisplay.cfm?deid=158823 
Umwelt Bundes Amt. German Federal Environment Agency. Health and Environmental Hygiene. German Environmental Survey (GerES) [Internet]. 2006; [citado 7 out 2008]. Disponível em: http://www.umweltbundesamt.de/gesundheit-e/monitor/index.htm.

Umwelt Bundes Amt. German Federal Environment Agency. Health and Environmental Hygiene. Reference and HBM values (definitions and tables) [Internet]. 2008 [citado 7 out 2008]. Disponível em: http://www.umweltbundesamt.de/gesundheit-e/monitordefinitionen.htm.

United Nations Environment Programme. Global Mercury Assessment. Geneva: UNEP Chemicals; 2002.

United States Environmental Protection Agency. EPA's Draft Report on the Environmet 2003: Technical Document. EUA; 2003. Chapter 4: Human Health.

United States Environmental Protection Agency. National ambient air quality standards for lead. Final rule. Federal Register. 200812 nov; 73(219):66964-7062

Vahter M, Berglund M, Åkesson A, Lidén C. Metals and women's health. Environ Res. 2002; 88: 145-55.

Watanabe T, Iwani O, Shimbo S, Ikeda M. Reduction in cadmium in blood and dietary intake among general populations in Japan. Int Arch Occup Environ Health. 1993; 65: S205-S208.

Webber CE, Chettle DR, Bowins RJ, Beaumont LF, Gordon CL, Song X, Blake JM, McNutt RH. Hormone Replacement Therapy May reduce the Return of Endogenous Lead from Bone to the Circulation. Environ Health Perspec. 1995; 103: 1-8. 
Wennberg M, Lundh T, Bergdahl IA, Hallmans G, Jansson JH, Stegmayr B, Custodio HM, Skerfving S. Time trends in burdens of cadmium, lead, and mercury in the population of northern Sweden. Environ Res. 2006; 100: 330-8.

Weyermann M, Brenner $\mathrm{H}$. Alcohol consumption and smoking habits as determinants of blood lead levels in a national population sample from Germany. Arch Environ Health. 1997; 52: 233-9.

Weyermann $M$, Brenner $H$. Factors affecting bone demineralization and blood lead levels of postmenopausal women - A population-based study from Germany. Environ Res. 1998; 76:19-25.

Wilhelm M, Eberwein G, Hölzer J, Begerow J, Sugiri D, Gladtke D, Ranft U. Human biomonitoring of cadmium and lead exposure of child-mother pairs from Germany living in the vicinity of industrial sources (Hot spot study NRW). J Trace Elem Med Biol. 2005;19: 83-90.

Wilhelm M, Ewers U, Schulz C. Revised and new reference values for some trace elements in blood and urine for human biomonitoring in environmental medicine. Int J Hyg Environ Health. 2004; 207: 69-73.

Wilhelm M, Pesch A, Rostek U, Begerow J, Schmitz N, Idel H, Ranft U. Concentrations of lead in blood, hair and saliva of German children living in three different areas of traffic density. Sci Total Environ. 2002; 297: 109-18.

Wilhelm M, Schulz C, Schwenk M. Revised and new reference values for arsenic, cadmium, lead and Mercury in blood or urine of children: Basis for validation of human biomonitoring data in environmental medicine. Int $\mathrm{J}$ Hyg Environ Health. 2006; 209: 301-5.

World Health Organization. Cadmium. Geneva: WHO, 1992. (Environmental Health Criteria 134). 
World Health Organization. Biomarkers and risk assessment: Concept and principles. Geneva: WHO; 1993. (Environmental Health Criteria; n. 155).

World Health Organization. Inorganic lead. Geneva: WHO, 1995. (Environmental Health Criteria 165).

World Health Organization. Human Exposure Assessment. Geneva: WHO; 2000a (Environmental Health Criteria; n. 214).

World Health Organization. Air Quality Guidelines for Europe $2^{\text {nd }}$ Ed. Copenhagen: WHO, 2000b. (WHO Regional Publications, European Series, No. 91).

World Health Organization. Health risks of heavy metals from long-range transboundary air pollution. 2007. Disponivel em : http://www.euro.who.int/document/E91044.pdf

Yassi A, Kjellström T. Enciclopedia de Salud y Seguridad en el Trabajo. Madri: OIT; 2001. v. II, p. 53.2-53.5: Conexiones entre la salud ambiental y la salud en el trabajo.

Zielhuis RL, Del Castilho P, Herber RFM, Wibowo AAE. Levels of lead and other metals in human blood: Suggestive relationships, determining factors. Environ Health Perspec. 1978; 25: 103-9. 